\title{
EFFECTS OF INCREASED URBANIZATION FROM 1970'S TO 1990'S ON STORM-RUNOFF CHARACTERISTICS IN PERRIS VALLEY, CALIFORNIA
}

By JOEL R. GUAY

\section{U.S. GEOLOGICAL SURVEY}

Water-Resources Investigations Report 95-4273

Prepared in cooperation with the RIVERSIDE COUNTY FLOOD CONTROL AND WATER CONSERVATION DISTRICT

$\frac{9}{8}$

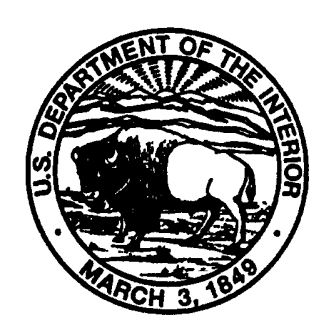




\section{U.S. DEPARTMENT OF THE INTERIOR}

BRUCE BABBITT, Secretary

U.S. GEOLOGICAL SURVEY

Gordon P. Eaton, Director

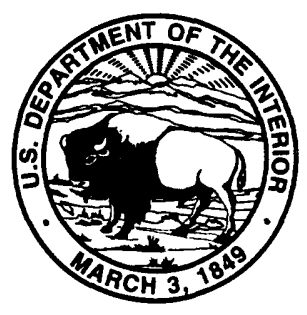

The use of firm, trade, and brand names in this report is for identification purposes only and does not constitute endorsement by the U.S. Geological Survey.

For addtional information write to:

District Chief

U.S. Geological Survey

Federal Building, Room W-2233

2800 Cottage Way

Sacramento, CA 95825
Copies of this report can be purchased from:

\section{U.S. Geological Survey}

Earth Science Information Center

Open-File Report Section

Box 25286, Mail Stop 417

Denver Federal Center

Denver, CO 80225 


\section{CONTENTS}

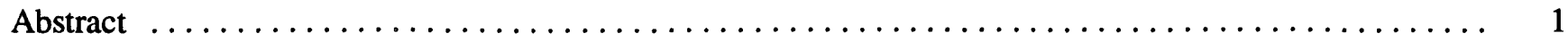

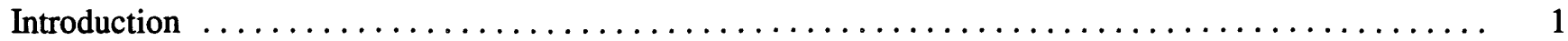

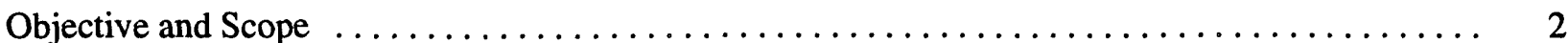

Previous Studies ........................................... 2

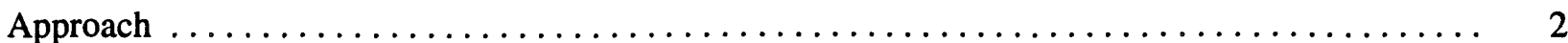

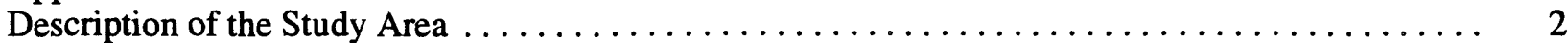

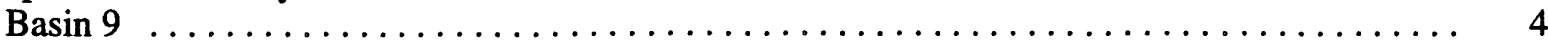

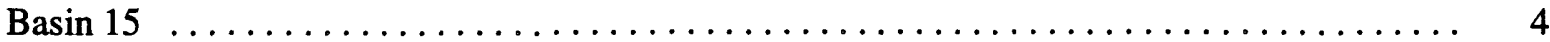

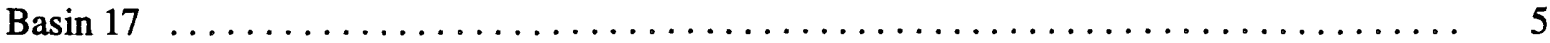

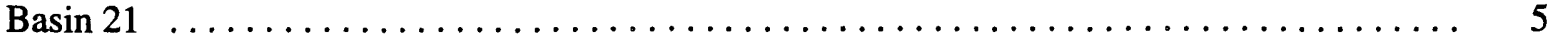

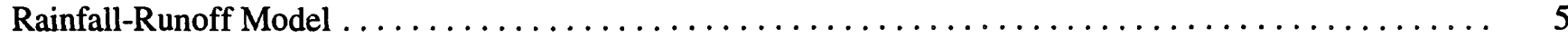

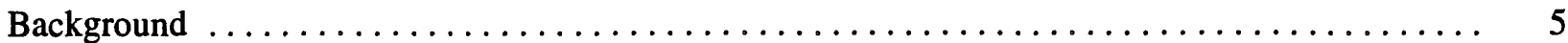

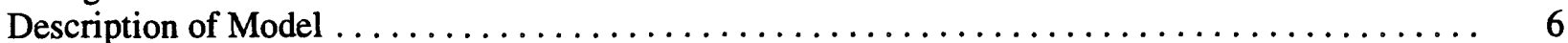

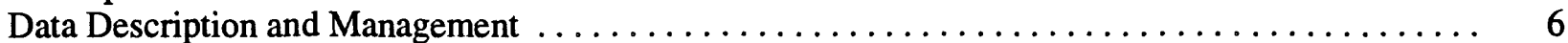

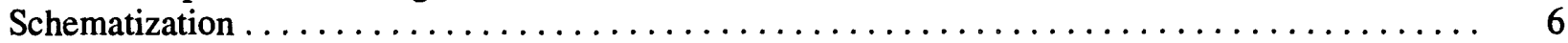

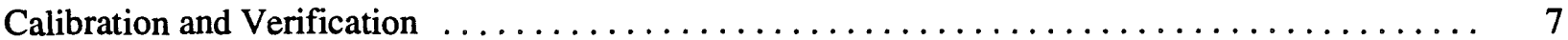

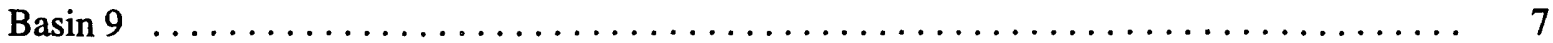

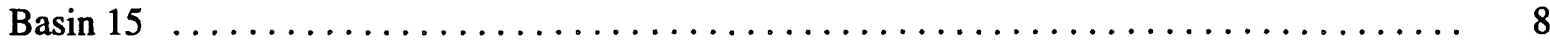

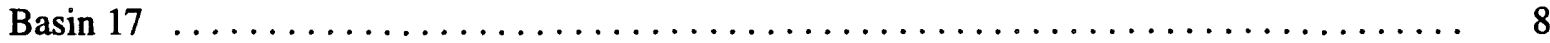

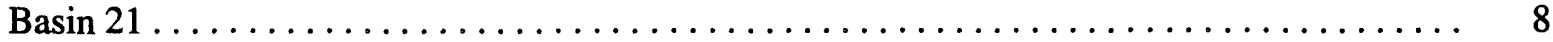

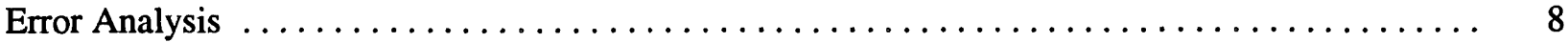

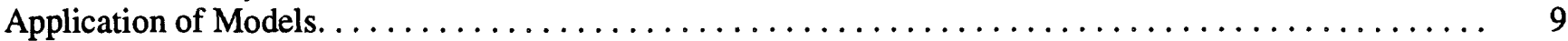

Frequency Analysis of Long-Term Rainfall and Simulated Annual Peak Discharges

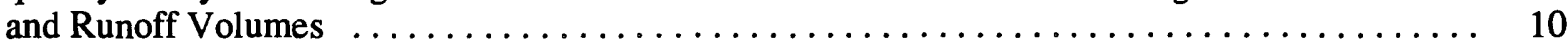

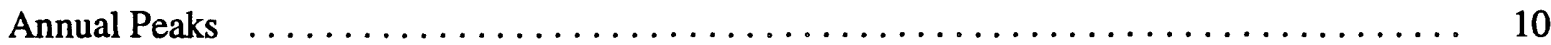

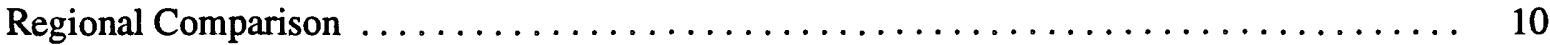

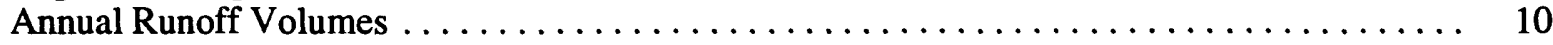

Duration Analysis of Simulated Storm Runoff Peaks $\ldots \ldots \ldots \ldots \ldots \ldots \ldots \ldots \ldots \ldots \ldots \ldots \ldots$

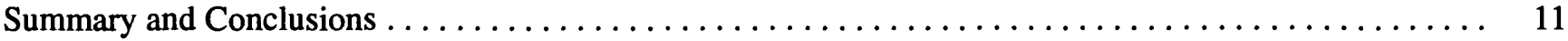

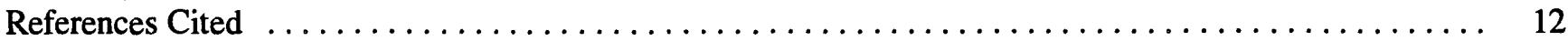

\section{FIGURES}

1-8. Maps showing:

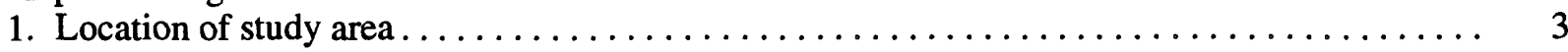

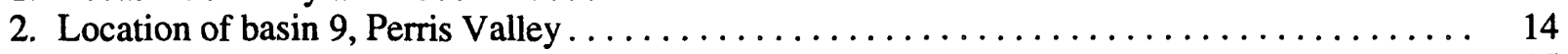

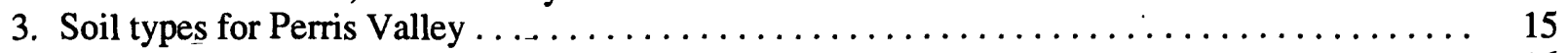

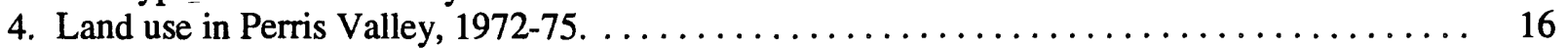

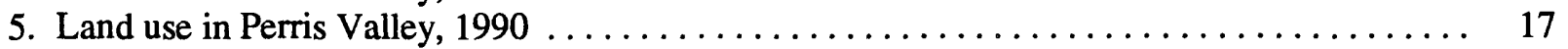

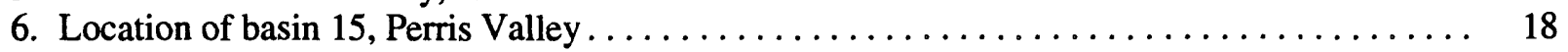

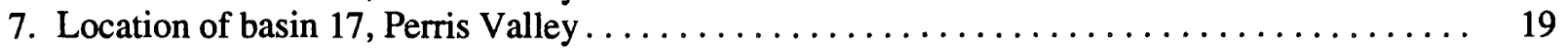

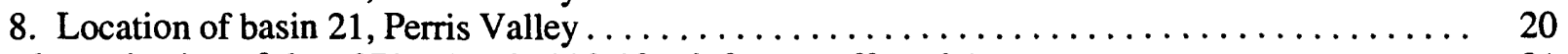

9. Schematization of the $1970-75$ and $1990-93$ rainfall-runoff models $\ldots \ldots \ldots \ldots \ldots \ldots \ldots \ldots$

10-22. Graphs showing:

10. Measured and simulated discharge for a selected storm used to calibrate the 1970-75

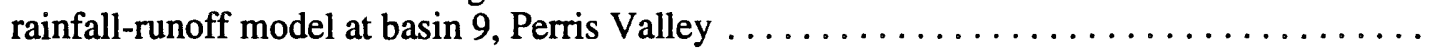


11. Measured and simulated discharge for two selected storms used to calibrate and verify the $1990-93$ rainfall-runoff model at basin 9, Perris Valley . . . . . . . . . . . . . . .

12. Measured and simulated discharge for a selected storm used to calibrate the $1970-75$

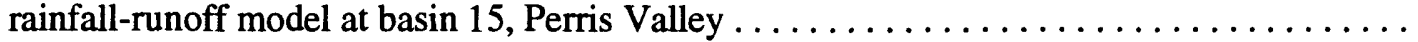

13. Measured and simulated discharge for two selected storms used to calibrate and verify the $1990-93$ rainfall-runoff model at basin 15, Perris Valley . . . . . . . . . . . . . . .

14. Measured and simulated discharge for a selected storm used to calibrate the 1970-75

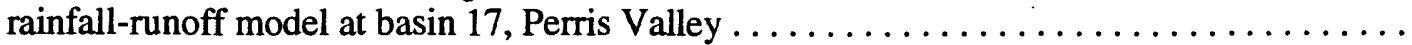

15. Measured and simulated discharge for a selected storm used to calibrate the 1990-93

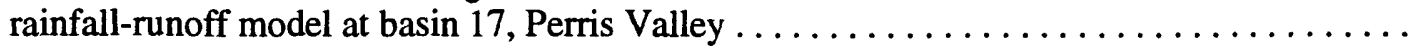

16. Measured and simulated discharge for a selected storm used to calibrate the 1970-75 rainfall-runoff model at basin 21 , Perris Valley .......................

17. Measured and simulated discharge for two selected storms used to calibrate and verify the $1990-93$ rainfall-runoff model at basin 21 , Perris Valley . . . . . . . . . . . . . .

18. Simulated annual peak discharges for the 1970-75 and 1990-93 conditions at basins 9,15 ,

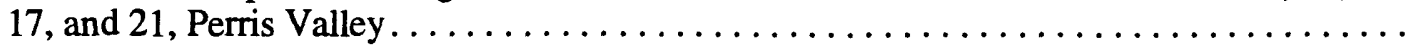

19. Simulated annual runoff volumes for the 1970-75 and 1990-93 conditions at basins $9,15,17$, and 21, Perris Valley. . . . . . . . . . . . . . . . . . . . . . . . . . . . .

20. Frequency analyses of annual peak discharges for the 1970-75 and 1990-93 conditions at basins $9,15,17$, and 21 , Perris Valley . . . . . . . . . . . . . . . . . . . . .

21. Frequency analyses of annual runoff volumes for the 1970-75 and 1990-93 conditions at

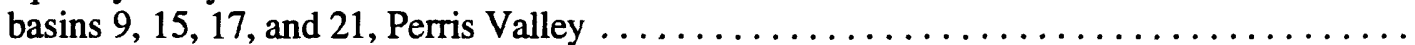

22. Duration analyses of storm runoff peaks for the $1970-75$ and $1990-93$ conditions at basins 9 ,

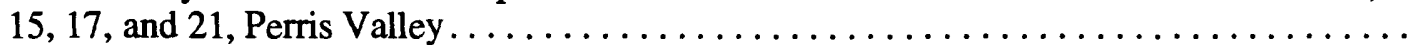

\section{TABLES}

1. Hydrologic and land-use characteristics of the basins, Perris Valley, $1972-75 \ldots \ldots \ldots \ldots \ldots$

2. Hydrologic and land-use characteristics of the basins, Perris Valley, $1990 \ldots \ldots \ldots \ldots \ldots \ldots \ldots$

3. Components for soil-moisture accounting and infiltration in the rainfall-runoff model $\ldots \ldots \ldots \ldots$

4. Segments of the four basins used in the 1970-75 rainfall-runoff model for Perris Valley . . . . . . . . .

5. Segments of the four basins used in the 1990-93 rainfall-runoff model for Perris Valley ...........

6. Summary of measured rainfall and runoff data used to calibrate the 1970-75 rainfall-runoff model ...

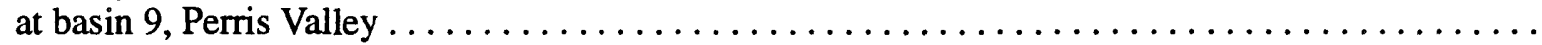

7. Measured and simulated runoff volumes and peak discharges for all storms used in calibration of the 1970-75 rainfall-runoff model at basin 9 , Perris Valley . . . . . . . . . . . . . . . . . .

8. Final values for soil-moisture and infiltration components, Perris Valley . . . . . . . . . . . . .

9. Summary of rainfall and runoff data used to calibrate and verify the $1990-93$ rainfall-runoff model

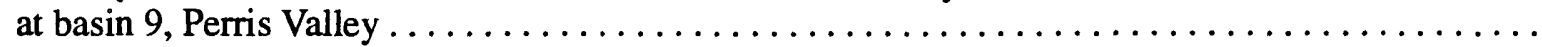

10. Measured and simulated runoff volumes and peak discharges for all storms used in calibration and verification of the 1990-93 rainfall-runoff model at basin 9, Perris Valley. . . . . . . . . . . . .

11. Summary of rainfall and runoff data used to calibrate the $1970-75$ rainfall-runoff model at basin 15 ,

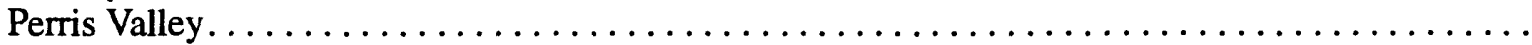

12. Measured and simulated runoff volumes and peak discharges for all storms used in calibration of the $1970-75$ rainfall-runoff model at basin 15 , Perris Valley . . . . . . . . . . . . . . . . . .

13. Summary of rainfall and runoff data used to calibrate and verify the $1990-93$ rainfall-runoff model

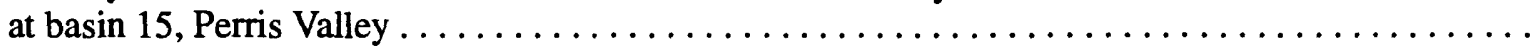

14. Measured and simulated runoff volumes and peak discharges for all storms used in calibration and verification of the 1990-93 rainfall-runoff model at basin 15, Perris Valley . . . . . . . . . . . .

15. Summary of rainfall and runoff data used to calibrate the $1970-75$ rainfall-runoff model at basin 17 ,

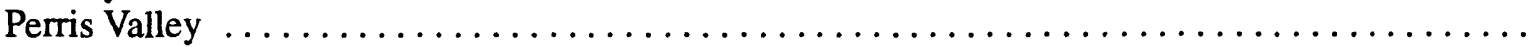

16. Measured and simulated runoff volumes and peak discharges for all storms used in calibration of the $1970-75$ rainfall-runoff model at basin 17 , Perris Valley $\ldots \ldots \ldots \ldots \ldots \ldots \ldots \ldots \ldots$ 
17. Summary of rainfall and runoff data used to calibrate the 1990-93 rainfall-runoff model at basin 17 ,

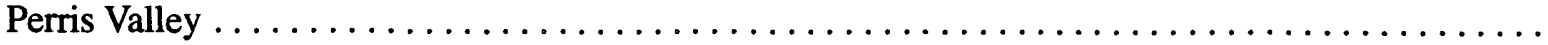

18. Measured and simulated runoff volumes and peak discharges for all storms used in calibration of the 1990-93 rainfall-runoff model at basin 17 , Perris Valley . . . . . . . . . . . . . . . . . . . . 50

19. Summary of rainfall and runoff data used to calibrate the $1970-75$ rainfall-runoff model at basin 21 ,

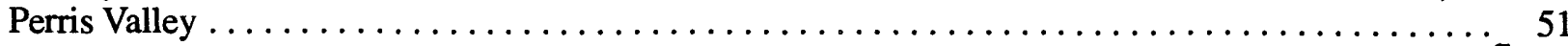

20. Measured and simulated runoff volumes and peak discharges for all storms used in calibration of the 1970-75 rainfall-runoff model at basin 21, Perris Valley . . . . . . . . . . . . . . . . . . 51

21. Summary of rainfall and runoff data used to calibrate and verify the $1990-93$ rainfall-runoff model at basin 21 , Perris Valley .................................. 52

22. Measured and simulated runoff volumes and peak discharges for all storms used in calibration and verification of the $1990-93$ rainfall-runoff model at basin 21, Perris Valley . . . . . . . . . . . 53

23. Median absolute deviation errors for calibration and verification of runoff volumes and peak discharges,

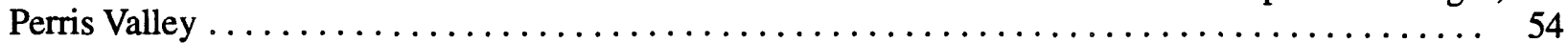

24. Monthly rainfall totals at Riverside Citrus Experimental Station and at basin 15 , Perris Valley ...... 54

25. Summary of monthly and annual rainfall totals at Riverside Citrus Experimental Station. . . . . . . . . 55

26. Summary of simulated annual peak discharges for the models representing the 1970-75 and 1990-93

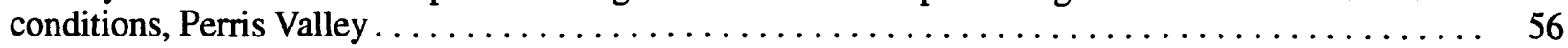

27. Summary of simulated annual runoff volumes for the models representing the 1970-75 and 1990-93

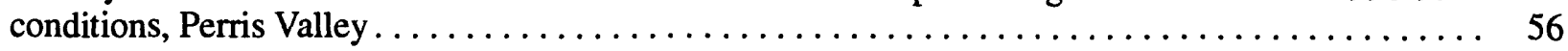

28. Summary of simulated storm peak discharges for the models representing the 1970-75 and 1990-93

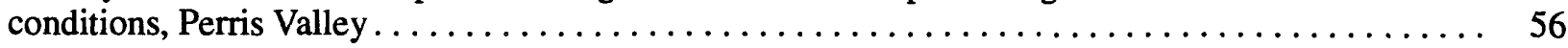

29. Model and regional frequency analyses of annual peak discharges at basins $9,15,17$, and 21 ,

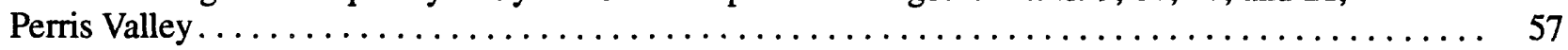

30. Model frequency analyses of annual runoff volumes at basins $9,15,17$, and 21 , Perris Valley. . . . 59

\section{CONVERSION FACTORS AND VERTICAL DATUM}

\section{Conversion Factors}

\begin{tabular}{rll}
\hline Multiply & By & To obtain \\
acre & 4,047 & square meter \\
acre-foot & 1,233 & cubic meter \\
cubic foot $\left(\mathrm{ft}^{3}\right)$ & 0.02832 & cubic meter \\
cubic foot per second $\left(\mathrm{ft}^{3} / \mathrm{s}\right)$ & 0.02832 & cubic meter per second \\
foot $(\mathrm{ft})$ & 0.3048 & meter \\
foot per mile $(\mathrm{ft} / \mathrm{mi})$ & 0.4904 & meter per kilometer \\
inch $(\mathrm{in})$. & 2.54 & centimeter \\
inch per hour $(\mathrm{in} / \mathrm{h})$ & 2.54 & centimeter per hour \\
mile $(\mathrm{mi})$ & 1.609 & kilometer \\
square foot $\left(\mathrm{ft}^{2}\right)$ & 0.09290 & square meter \\
square mile $\left(\mathrm{mi}^{2}\right)$ & 2.590 & square kilometer \\
\hline
\end{tabular}

\section{Vertical Datum}

Sea level: In this report, "sea level" refers to the National Geodetic Vertical Datum of 1929 - a geodetic datum derived from a general adjustment of the first-order level nets of the United States and Canada, formerly called Sea Level Datum of 1929. 
$-$ 


\title{
Effects of Increased Urbanization from 1970's to 1990's on Storm-Runoff Characteristics in Perris Valley, California
}

\author{
By Joel R. Guay
}

\section{Abstract}

Urban areas in Perris Valley, California, have more than tripled during the last 20 years. To quantify the effects of increased urbanization on storm runoff volumes and peak discharges, rainfall-runoff models of the basin were developed to simulate runoff for 1970-75 and 1990-93 conditions. Hourly rainfall data for 1949-93 were used with the rainfall-runoff models to simulate a long-term record of storm runoff. The hydrologic effects of increased urbanization from 1970-75 to 1990-93 were analyzed by comparing the simulated annual peak discharges and volumes, and storm runoff peaks, frequency of annual peak discharges and runoff volumes, and duration of storm peak discharges for each study period.

A Log-Pearson Type-III frequency analysis was calculated using the simulated annual peaks to estimate the 2-, 5-, 10-, 25-, 50-, and 100-year recurrence intervals. The estimated 2-year discharge at the outlet of the basin was 646 cubic feet per second for the 1970-75 conditions and 1,328 cubic feet per second for the 1990-93 conditions. The 100-year discharge at the outlet of the basin was about 14,000 cubic feet per second for the 1970-75 and 1990-93 conditions.

The station duration analysis used 925 model-simulated storm peaks from each basin to estimate the percent chance a peak discharge is exceeded. At the outlet of the basin, the chances of exceeding 100 cubic feet per second were about 33 percent under $1970-75$ conditions and about 59 percent under 1990-93 conditions. The chance of exceeding 2,500 cubic feet per second at the outlet of the basin was less than 1 percent higher under the 1990-93 conditions than under the $1970-75$ conditions. The increase in urbanization from the early 1970's to the early 1990's more than doubled the peak discharges with a 2year return period. However, peak discharges with return periods greater than 50 years were not significantly affected by the change in urbanization.

\section{INTRODUCTION}

Increased urbanization in Perris Valley, California, since the early 1970's has altered the drainage characteristics of the Perris Valley drainage basin. The construction of parking lots, streets, sidewalks, homes, and buildings creates impervious surfaces that typically increase storm runoff volumes and peak discharges. The urban areas in Perris Valley have more than tripled in size during the last 20 years, from about 10 percent urban area in the early 1970's to more than 36 percent in the early 1990 's.

The effects of this urbanization have been a growing concern to local flood control managers. The Riverside County Flood Control and Water Conservation District (RCFC/WCD) is responsible for flood control and drainage activities in the Perris Valley drainage area. The flood control systems are designed, constructed, and operated to manage urban runoff and 
include dams, detention basins, open channels, and underground storm drains. Beginning in 1989, the U.S. Geological Survey (USGS) and the RCFC/WCD began a cooperative study to assess the effects of urban growth on storm runoff volumes and peak discharges in the Perris Valley drainage system.

\section{OBJECTIVE AND SCOPE}

This report describes the results of a study designed to (1) collect rainfall and runoff data at four previously gaged stations in Perris Valley for water years 1990-93, (2) apply the Distributed Routing Rainfall-Runoff Model (DR3M-II) at those stations to simulate the hydrologic conditions during 1970-75 and 1990-93, and (3) use the model output of the two simulation periods to determine the effects of increased urbanization on runoff characteristics in Perris Valley since the early 1970 's.

\section{PREVIOUS STUDIES}

Troxell (1948) studied the hydrology of western Riverside County in the late 1940's and tried to further understand the elements that enter into or influence precipitation, runoff, and the rainfall-runoff relationship.

Durbin (1974) used the Stanford Watershed Model to simulate the effects of urbanization on the discharge from five drainage basins in the upper Santa Ana Valley. The model was used to simulate a streamflow record of each basin representing various degrees of urbanization. According to Durbin, "Urbanization can increase the magnitude of peak discharge and daily mean discharge with a recurrence interval of 2 years by a factor of three to six. Peak discharges and daily mean discharges that have recurrence intervals greater than a limiting value ranging from 50 to 200 years or more are little affected by urbanization."

Lang (1979) collected rainfall-runoff data in Perris Valley at 21 sites from 1970-75 to try to identify the effects of urbanization on rainfall-runoff characteristics. This could not be done because of unfavorable climatic conditions and the lack of urban development during the study period, but the data in the report form the background for additional hydrologic investigations of Perris Valley.

\section{APPROACH}

Data from a previous study (Lang, 1979) were used to calibrate rainfall-runoff models simulating the hydrologic conditions during $1970-75$ for four subbasins. Data collected from 1990-93 were used to calibrate and verify (where data were available) rainfall-runoff models simulating 1990-93 hydrologic conditions for the same four subbasins. Model error was estimated by comparing measured and simulated runoff volumes and peak discharges.

To analyze the effects of increased urbanization, two rainfall-runoff models were developed: one for early 1970's conditions and the other for early 1990's conditions. The hydrologic effects of increased urbanization from 1970-75 to 1990-93 conditions were analyzed by comparing the frequency of annual peak discharges and runoff volumes and the duration of storm peak discharges for each study period.

\section{DESCRIPTION OF THE STUDY AREA}

Perris Valley (fig. 1) is in Riverside County about $60 \mathrm{mi}$ east of Los Angeles and just southeast of Riverside. The study area encompasses $93.27 \mathrm{mi}^{2}$ in the lower San Jacinto River Basin. It is bounded on the east by the San Jacinto Valley, on the west by the Temescal Plateau, on the north by the Badlands and Box Springs Mountains, and on the south by the City of Perris (Lang, 1979). Land-surface altitudes in the study area generally range from about $1,400 \mathrm{ft}$ above sea level on the valley floor to about $3,000 \mathrm{ft}$ on the higher peaks of the surrounding mountains. Stream gradients on the valley floor are variable, but average about 1 percent. However, stream gradients in the northern part of the study area exceed about 7 percent. The streams flow only in response to periods of sustained rainfall. The mountains surrounding the alluvial valley are mostly granite and are generally nonwaterbearing.

The climate of Perris Valley is classified as subtropical desert (Troxell, 1948). Native vegetation is sparse and consists largely of cactus and associated mesophytes and xerophytes. Precipitation generally occurs from November to May as a result of eastward movement of marine air masses and during August and September as a result of summer convectional thunderstorms. The average annual (1949-93) precipitation at the Riverside Citrus Experimental Station, about $3 \mathrm{mi}$ from the northwestern edge of the 


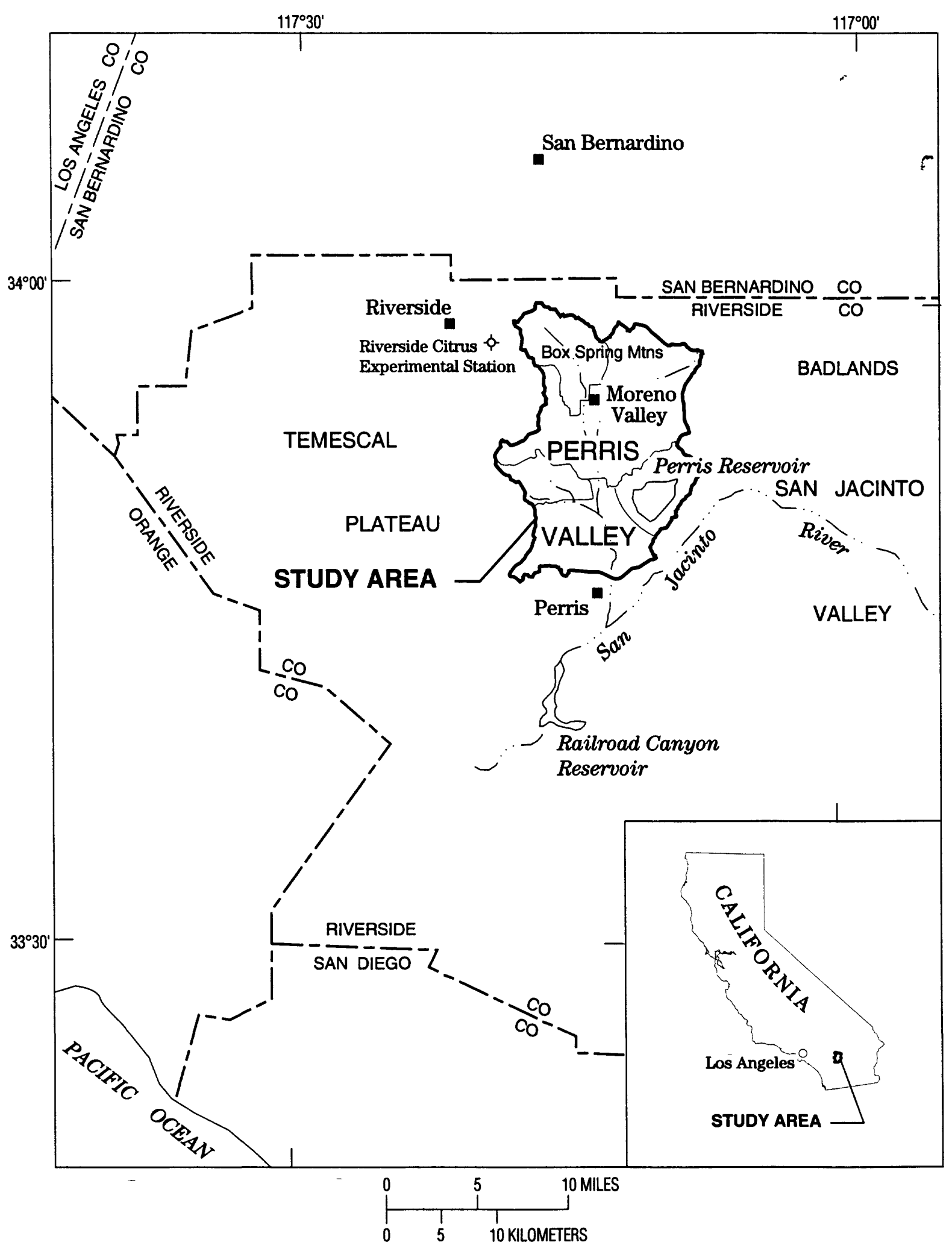

Figure 1. Location of study area. 
study area (fig. 1), is 9.51 in. The average annual rainfall was 7.88 in. during $1970-75$ and 13.08 in. during 1990-93.

Rainfall and runoff data used in the study were gaged at four drainage basin outfalls within the study area. The numbers of the drainage basins were retained from a previous 1970-75 study of the area. Drainage basin 9 includes the area designated subbasin $\mathrm{A}$ (fig. 2 , at back of report). Drainage basin 15 includes subbasins $A$ and $B$. Drainage basin 17 is equivalent to subbasin $C$, and drainage basin 21 includes subbasins A, B, C, and D. Subbasin E was not included in the drainage area because the flows from this subbasin are captured by Perris Reservoir.

Soils in the surrounding mountains are generally shallow to moderately deep and well drained (fig. 3, at back of report). Soils on the west side of the valley floor are shallow to deep and well drained. Soils on the east side of the valley floor are deep and well drained.

The urban land use was about 10 percent during the period 1970-75 (fig. 4 and table 1, at back of report). For the period 1990-93, the urban area increased to about 33 percent (fig. 5 and table 2, at back of report).

\section{BASIN 9}

Drainage basin 9 (fig. 2), also referred to as subbasin A, encompasses $13.52 \mathrm{mi}^{2}$. Most soils (fig. 3) in basin 9 are classified as the Hanford-TujungaGreenfield association, which are deep, well-drained to excessively drained, nearly level to moderately steep soils that have a surface layer of sand to sandy loam. These soils are found on alluvial fans and flood plains (Knecht, 1971). Soils in the steep headlands of the basin are classified as the Cieneba-Rock landFallbrook association, which are well-drained to somewhat excessively drained, undulating to steep, very shallow to moderately deep soils that have a surface layer of sandy loam and fine sandy loam. These soils are found on granitic rock. A small section in the southwestern section of the basin has soils classified as the Monserate-Arlington-Exeter association. These soils are well drained and nearly level to moderately steep. They have a surface layer of sandy loam to loam and are shallow to deep.

During 1970-75, land use in basin 9 was about 15 percent urban, 46 percent agriculture, and 39 percent undeveloped (fig. 4 and table 1). Undeveloped area for 1970-75 includes military vacant, range/open, strip mines, quarries, gravel pits, transitional areas, and detention storage. Total impervious area (hereafter referred to as impervious area) was about 11 percent. In 1990, the basin was about 48 percent urban, 2 percent agriculture, and 50 percent undeveloped. Undeveloped area for 1990-93 includes urban vacant, military vacant, range/open, and detention storage. The impervious area increased to about 27 percent (fig. 5 and table 2).

The headwaters of the basin drain into the Poorman Reservoir (fig. 2), which collects runoff from $8.67 \mathrm{mi}^{2}$ or about 64 percent of the basin. The reservoir is controlled by a $2.5-\mathrm{ft}$ pipe outlet with a design capacity of $130 \mathrm{ft}^{3} / \mathrm{s}$. When full, the reservoir can be drained in about 2 days. For the 1990-93 conditions, a second retention basin (Indian Street) captures outflow from the Poorman Reservoir and from an additional $1.29 \mathrm{mi}^{2}$ of the drainage basin. The reservoir outflow is a 72 -in. pipe with a 100 -year maximum release of $313 \mathrm{ft}^{3} / \mathrm{s}$. The gaging station that measures flow from basin 9 is downstream of a double 12- by $6-\mathrm{ft}$ concrete box culvert near the corner of Alessandro Boulevard and Heacock Street.

\section{BASIN 15}

Drainage basin 15 (fig. 6, at back of report) encompasses $54.22 \mathrm{mi}^{2}$ and includes subbasins $A$ and B. Subbasin B is dominated by soils (fig. 3 ) classified as the Hartford-Tujunga-Greenfield association (Knecht, 1971). The Cieneba-Rock land-Fallbrook association soils are found in the northern and southeastern parts of the basin, and the MonserateArlington-Exeter soils are found in the western part. Soils in the eastern part are classified as the San Emigdio-Grangeville-Metz association, which are very deep, poorly drained to somewhat excessively drained, nearly level to strongly sloping soils that have a surface layer of calcareous loamy sand to loam. These soils are found on alluvial fans and flood plains. In the northeastern part of the basin, soils are classified as the Badland-San Timoteo association, which are welldrained, rolling to very steep, moderately deep, calcareous loam and very shallow soils. These soils are found on inland sea sediment and soft sandstone.

Basin 15 was about 10 percent urban, 57 percent agriculture, and 33 percent undeveloped during 197075 (fig. 4 and table 1). About 8 percent of the land was impervious. During 1990-93, land use was classified as 41 percent urban, 15 percent agriculture, and 44 
percent undeveloped (fig. 5 and table 2). Impervious areas totaled about 24 percent of the basin.

The major drainage channel for subbasin $B$ is the Perris Valley Storm Drain. Runoff west of Heacock Street generally flows in a southeasterly direction, and runoff east of Heacock Street generally flows in a southwesterly direction toward the Perris Valley Storm Drain. The gaging station for basin 15 is about onehalf mile east of the intersection of Perris Boulevard and Nandina Avenue (fig. 6).

\section{BASIN 17}

Drainage basin 17 (subbasin C) (fig. 7, at back of report) encompasses $6.99 \mathrm{mi}^{2}$. Most soils (fig. 3) in basin 17 are classified as the Monserate-ArlingtonExeter association (Knecht, 1971). In the western third of the basin, the soils are the Cieneba-Rock LandFallbrook association.

Land use in basin 17 during 1970-75 was classified as about 20 percent urban, 27 percent agriculture, and 53 percent undeveloped (fig. 4 and table 1). The impervious area was about 9 percent. The 1990-93 land use was about 41 percent urban, 18 percent agriculture, and 41 percent undeveloped (fig. 5 and table 2). About 17 percent of the basin was impervious.

Runoff west of the March Air Force Base runway generally flows east to a channel directing the flow southeast to the Perris Valley Storm Drain. Runoff east of the runway flows south to the Perris Valley Storm Drain. The gaging station for basin 17 is near the intersection of Perris Valley Storm Drain and Perris Boulevard, about one-half mile south of Nandina Avenue (fig. 7).

\section{BASIN 21}

Drainage basin 21 (the entire study area) (fig. 8, at back of report) encompasses $93.47 \mathrm{mi}^{2}$ and includes subbasins A, B, C, D, and E. However, runoff from subbasin E $\left(7.14 \mathrm{mi}^{2}\right)$ is captured by the Perris Reservoir and is not included in the storm runoff drainage area. Therefore, the effective drainage area is $86.33 \mathrm{mi}^{2}$. Soils (fig. 3) in the middle of the additional area (subbasins D and E) are classified as the HanfordTujunga-Greenfield and the Monserate-ArlingtonExeter association (Knecht, 1971). Soils in the surrounding areas are classified as the Cieneba-Rock land-Fallbrook association. Soils near the gaging station are classified as the Traver-Domino-Willows association, which are moderately well-drained to poorly drained, nearly level to gently sloping, salinealkali soils that have a surface layer of loamy fine sand to silty clay and are moderately deep to very deep.

During 1970-75, basin 21 was about 10 percent urban, 60 percent agriculture, and 30 percent undeveloped (fig. 4 and table 1). About 8 percent of the basin was impervious. In 1990-93, the basin was about 36 percent urban, 22 percent agriculture, and 42 percent undeveloped (fig. 5 and table 2). About 22 percent of the basin was impervious.

The main drainage channel for subbasin $D$ is the Perris Valley Storm Drain, which runs almost due south from gaging station 15 (fig. 8). Runoff west of the storm drain generally flows southeast, and runoff east of the storm drain generally flows southwest. The gaging station for basin 21 is near the intersection of Perris Valley Storm Drain and Nuevo Road.

\section{RAINFALL-RUNOFF MODEL}

\section{BACKGROUND}

The U.S. Geological Survey has been involved in urban studies since the late 1950's. From early studies that emphasized flood and sediment problems, the Survey began developing simulation models in the late 1960's. This research produced a lumpedparameter, rainfall-runoff model (Dawdy and others, 1972) that was based on the unit-hydrograph method. In 1978, a Distributed Routing Rainfall-Runoff Model (DR3M) was completed that incorporated a hydraulic approach to routing runoff. This model was adapted from the Massachusetts Institute of Technology catchment model (LeClerc and Schaake, 1973) and is described in reports by Dawdy and others (1978) and Alley and others (1980). Later research produced an improved version of the DR3M model (DR3M-II) (Smith and Alley, 1982). The DR3M-II rainfall-runoff model was used in this study because it simulates the drainage features (overland flow planes, pipes, gutters) associated with an urban environment.

The DR3M-II model has recently been applied to catchments in or near Fresno, California (Guay and Smith, 1988); Chester County, Pennsylvania, (Sloto, 1988); Salt Lake City, Utah (Lindskov and Thompson, 1989); Trenton, New Jersey (Fulton, 1990); 
Mississippi (Prasad and DeLeeuw, 1990);

Albuquerque, New Mexico (Thomas, 1990); and

Hartford, Connecticut (Weiss, 1990). The goal of the

Survey's urban studies program is, in part, to continue to develop improved methods for analyzing urban hydrologic data, which includes determining characteristics of urban runoff, developing methods to transfer information to ungaged drainage basins, and evaluating the effectiveness of stormwater management practices.

\section{DESCRIPTION OF MODEL}

The rainfall-runoff model (DR3M-II) continuously simulates stormwater hydrographs from rainfall input and a physical description of the drainage basin and attempts to describe the actual physical processes that occur in the drainage basin. In the model, a drainage basin is represented as a set of overland-flow and channel segments, which are combined to describe the drainage features of the basin. Unsteady flow-routing methods are used to simulate the movement of runoff over contributing overlandflow areas and through the channel network. Infiltration in pervious areas is modeled on the basis of a variation of the Green-Ampt equation (Green and Ampt, 1911). DR3M-II was developed principally for application to urban drainage basins. Additional documentation of the model is given in a report by Alley and Smith (1982).

DR3M-II simulates on two different time intervals. A short time interval (1 minute to 1 hour) is used for infiltration and routing calculations during days on which short-time-interval storm rainfall is entered into the program. Flows are routed by the model only during these short-time-interval days, referred to as unit days. Between unit days, DR3M-II simulates on a daily time interval using daily precipitation and evaporation data to perform an accounting of soil moisture.

\section{DATA DESCRIPTION AND MANAGEMENT}

Rainfall and runoff data for 1970-75 and 199093 were recorded at 15-minute intervals at gaging stations $9,15,17$, and 21 . Rainfall was recorded in 0.01 -in. increments by a tipping-bucket rain gage at each station. Discharges were calculated using a stagedischarge relation. Peak flows for 1970-75 were
$153 \mathrm{ft}^{3} / \mathrm{s}$ at gaging station $9 ; 488 \mathrm{ft}^{3} / \mathrm{s}$ at gaging station $15 ; 89 \mathrm{ft}^{3} / \mathrm{s}$ at gaging station 17 ; and $914 \mathrm{ft}^{3} / \mathrm{s}$ at gaging station 21 . From slope-area computations, a storm peak of $5,670 \mathrm{ft}^{3} / \mathrm{s}$ at gaging station 21 , recorded on February 25, 1969, was used to compare the modelsimulated peak discharge for the same day. Peak flows for $1990-93$ were $1,300 \mathrm{ft}^{3} / \mathrm{s}$ at gaging station $9 ; 4,880$ $\mathrm{ft}^{3} / \mathrm{s}$ at gaging station $15 ; 307 \mathrm{ft}^{3} / \mathrm{s}$ at gaging station 17 ; and $4,400 \mathrm{ft}^{3} / \mathrm{s}$ at gaging station 21 . For modeling purposes, data for both periods were stored on online computer disks as part of a comprehensive drainage basin data-management system called ANNIE (Lumb and Kittle, 1985). ANNIE is a system of software modules developed by the Geological Survey to simplify the tasks of storing, retrieving, and preparing data sets for entry into the DR3M-II model. Watershed Data Management (WDM) files are used in ANNIE to store rainfall-runoff data.

\section{SCHEMATIZATION}

Each catchment was schematized into a series of segments that represented the physical runoff features of the catchment. The types of segments available in DR3M-II are channel, pipe, overland-flow plane, junction, and reservoir. Channel, pipe, and overlandflow plane segments were used in the Perris Valley rainfall-runoff models. Channel segments are defined by length, slope, roughness (Manning's $n$ ), and cross sectional geometry. Pipe segments are defined by flow length, slope, roughness, and diameter. Overland-flow planes are rectangular planes defined by flow length, slope, and a roughness coefficient. Overland-flow width is determined by the length of the channel segment it flows into. Manning's $n$ values were used for the roughness coefficients in all segments.

Segments were schematized using (1) surface drawings of streets and gutters, (2) aerial photographs of the catchments, (3) land-use maps of the basin, and (4) field inspection of the catchments. A digitizer was used to determine the overall catchment area and segment flow lengths. Aerial photographs and landuse maps were used to estimate the percentage of effective and noneffective impervious areas of the overland-flow planes (Guay and Smith, 1988).

The Perris Valley drainage basin was schematized into 14 overland-flow planes, 2 pipes ( 1 for 1970-75 conditions), and 8 channel segments (fig. 9 , at back of report). The two pipes simulated the 
controlled outflow through pipes at the Poorman and Indian Street Reservoirs (1990-93 conditions only). With the exception of Indian Street Reservoir, the number of segments used was identical for each period. Size of the overland-flow segments was adjusted to reflect the amount of urbanized area for each period. Basically, each basin was divided into two overlandflow planes: one for the pervious area and one for impervious urban areas. As urban area increased, pervious area decreased, but the total basin area stayed the same. However, basin 9 required seven overlandflow planes, two pipes (one for 1970-73 conditions), and four channels because the basin contained two reservoirs (one for 1970-73 conditions) and a very steep area in the northern part of the basin.

\section{CALIBRATION AND VERIFICATION}

The rainfall-runoff models were calibrated and verified by comparing measured and simulated storm runoff volumes, peak discharges, and hydrograph timing. The 1970-75 models were calibrated but not verified because fewer than 20 storms at each basin were available for modeling purposes. The general rule is that a minimum of 20 storms (10 each for calibration and verification) are required to calibrate and verify a rainfall-runoff model. The 1990-93 model for basin 17 had only eight storms available for modeling purposes; therefore, the model was calibrated but not verified. For all other basins, the measured 1990-93 rainfall-runoff data were divided into two unbiased data sets: one for calibration and one for verification. During calibration, model parameters were adjusted so that model output best agreed with the measured data, whereas during verification, model parameters were held constant. Storms were eliminated from data sets for various reasons: the rainfall record was missing, the runoff/rainfall ratios appeared too high or too low, the storms were too small to measure accurately, the stage record was affected by debris buildup or scour in the channel, or parts of the rainfall or runoff record were missing.

Storm runoff volumes were calibrated first using the model optimization procedure (Rosenbrock, 1960) to refine the estimates of effective impervious area and to determine the soil moisture and infiltration components that provided the best agreement between simulated and measured runoff volumes. When using the optimization procedure, only storms with runoff volumes sensitive to the components being optimized are included in the objective function.. The percentage of effective impervious area was optimized using only small storms from pervious areas. The soil moisture and infiltration components (table 3 , at back of report) were optimized using only large storms that had a significant part of the total runoff occurring from pervious areas.

Peak discharge and hydrograph timing were calibrated by adjusting the estimated slope and roughness of the modeled overland-flow planes. Overland-flow planes consist of many types of land surfaces, such as streets, sidewalks, driveways, parking lots, and roofs. The slope and roughness of overlandflow planes are difficult to determine where many of these features are combined into a single model segment. For this reason, slope and roughness are used as calibration parameters as long as the final values are realistic. The values for the overland-flow planes, pipes, and channels used in the two models are shown in tables 4 and 5, (at back of report). Because rainfall and runoff data were available for each basin, the results of each basin calibration/verification follows.

\section{BASIN 9}

Rainfall and runoff data from 14 storms (table 6, at back of report) were used to calibrate the 1970-75 rainfall-runoff model at basin 9 . The model-optimized values for effective impervious, noneffective impervious, and pervious areas are 3.6,7.1, and 89.3 percent, respectively. The DR3M-II model defines effective impervious surfaces as areas that drain directly into channel drainage systems; noneffective impervious surfaces are areas that drain to pervious areas. A hydrograph of measured and simulated discharge for a selected storm used in the calibration is shown in figure 10 (at back of report). Measured and simulated runoff volumes and peak discharges for all storms used in calibration are shown in table 7 (at back of report). Final optimized values for soil moisture and infiltration components at each catchment in the study are shown in table 8 (at back of report). The infiltration rates, primarily KSAT, were the same for the two simulation periods. KSAT, the effective saturated value of hydraulic conductivity, was about $0.2 \mathrm{in} / \mathrm{h}$.

Rainfall and runoff data from 30 storms (table 9, at back of report) were used to calibrate and verify the 1990-93 rainfall-runoff model at basin 9. The modeloptimized values for effective impervious, non- 
effective impervious, and pervious areas are 10,16.8, and 73.2 percent, respectively. Hydrographs of measured and simulated discharge for selected storms used in calibration and verification are shown in figure 11 (at back of report). Measured and simulated runoff volumes and peak discharges for all storms used in calibration and verification are shown in table 10 (at back of report).

\section{BASIN 15}

Rainfall and runoff data from 19 storms (table 11 , at back of report) were used to calibrate the 197075 model at basin 15 . The model-optimized values for effective impervious, noneffective impervious, and pervious areas are $2.8,5.5$, and 91.7 percent, respectively. A hydrograph of measured and simulated discharge for a selected storm used in the calibration is shown in figure 12 (at back of report). Measured and simulated runoff volumes and peak discharges for all storms used in calibration are summarized in table 12 (at back of report).

Rainfall and runoff data from 22 storms (table 13 , at back of report) were used to calibrate and verify the 1990-93 model at basin 15. The optimum values for effective impervious, noneffective impervious, and pervious areas are $8.4,15.3$, and 76.3 percent, respectively. Hydrographs of measured and simulated discharge for selected storms used in calibration and verification are shown in figure 13 (at back of report). Measured and simulated runoff volumes and peak discharges for all storms used in calibration and verification are summarized in table 14 (at back of report).

\section{BASIN 17}

Rainfall and runoff data from 11 storms (table 15 , at back of report) were used to calibrate the 197075 model at basin 17 . The model-optimized values for effective impervious, noneffective impervious, and pervious areas are 3.0,6.0, and 91.0 percent,

respectively. Hydrographs of measured and simulated discharge for selected storms used in the calibration are shown in figure 14 (at back of report). Measured and simulated runoff volumes and peak discharges for all storms used in calibration are summarized in table 16 (at back of report).

Rainfall and runoff data from eight storms (table 17 , at back of report) were used to calibrate the 1990 -
93 model at basin 17 . The optimum values for effective impervious, noneffective impervious, and pervious areas are 3.0, 14.4, and 82.6 percent, respectively. A hydrograph of measured and simulated discharge for a selected storm used in calibration is shown in figure 15 (at back of report). Measured and simulated runoff volumes and peak discharges for all storms used in calibration and verification are summarized in table 18 (at back of report).

\section{BASIN 21}

Rainfall and runoff data from six storms (table 19 , at back of report) were used to calibrate the 1970 75 model at basin 21 . The model-optimized values for effective impervious, noneffective impervious, and pervious areas are 2.3, 5.5, and 92.1 percent, respectively. A hydrograph of measured and simulated discharge for a selected storm used in the calibration is shown in figure 16 (at back of report). Measured and simulated runoff volumes and peak discharges for all storms used in calibration are summarized in table 20 (at back of report).

Rainfall and runoff data from 22 storms (table 21 , at back of report) were used to calibrate and verify the 1990-93 model at basin 21 . The optimum values for effective impervious, noneffective impervious, and pervious areas are 6.7,15.5, and 77.7 percent, respectively. Hydrographs of measured and simulated discharges for selected storms used in calibration and verification are shown in figure 17 (at back of report). Measured and simulated runoff volumes and peak discharges for all storms used in calibration and verification are summarized in table 22 (at back of report).

\section{ERROR ANALYSIS}

Simulation errors were summarized using the median absolute deviation (MAD), in percent:

where

$$
M A D=100 \times\left\{\operatorname{median}\left|\varepsilon_{i}\right|\right\}
$$

$\varepsilon_{i}$ is $\left(x_{i}-\hat{x}_{i}\right) / x_{i}$, and

$x_{i}$ and $\hat{x}_{i}$ are the $i$ th measured and simulated values, respectively.

The MAD criterion was used to summarize errors because it has the advantage of being insensitive to outliers. The average MAD errors for all four 1970- 
75 rainfall-runoff models were 36 and 29 percent for calibration of runoff volumes and peak discharges, respectively. The average MAD errors for all four 1990-93 rainfall-runoff models were 27 and 34 percent for calibration of runoff volumes and peak discharges, respectively, and 35 and 43 percent for verification of runoff volumes and peak discharges. The simulation errors for the 1970-75 and 1990-93 models are summarized in table 23 (at back of report).

\section{APPLICATION OF MODELS}

A long-term time series of simulated storm runoff was produced by using the 1970-75 and 1990-93 rainfall-runoff models with 45 years (1949-93) of hourly rainfall data from the Riverside Citrus Experimental Station. At each basin, 925 storms were simulated for the two study periods, for a total of 7,400 storms. A storm period began with the first rainfall and ended when rainfall had ceased for 24 hours.

Rainfall at the Riverside Citrus Experimental Station was compared with the Perris Valley basin 15 rainfall to determine if rainfall at the two stations was similar. A comparison of monthly and annual rainfall at the two stations for 1990-93 (table 24, at back of report) indicates the total rainfall during November through March was 2 percent higher at the Riverside Citrus Experimental Station; the median monthly total was 4 percent higher at the Riverside Citrus Experimental Station. These data indicate that rainfall at the Riverside Citrus Experimental Station is comparable to the Perris Valley rainfall.

The rainfall record at the Riverside Citrus Experimental Station for 1949-93 (table 25, at back of report) indicates that 88 percent of the rainfall occurs during November through March. January has the highest average rainfall with 2.06 in., followed by February with 1.79 in. The highest 1-month total was 9.32 in. recorded in January 1983. The highest annual rainfall total was 22.86 in. recorded in 1993 . The average annual rainfall at the Riverside Citrus Experimental Station is 9.51 in.

From the long-term simulated runoff for each model period, plots were developed to compare the annual peak discharges and volumes. Statistics were computed to compare the annual peak discharges and volumes and storm peak discharges of the two study periods. With the exception of basin 17, the plots comparing the annual peak discharges of the two models (fig. 18, at back of report) indicate that the relative difference in the peaks decreases as the peaks get larger. The larger difference in the smaller storm peaks reflects the difference in impervious areas of the two models. Smaller storms generate runoff mainly from impervious areas, whereas during large storms, runoff is generated from pervious areas as well. The impervious area increased 175 percent between the $1970-75$ and 1990-93 conditions, whereas there is only a 16-percent difference in the pervious areas between the 1970-75 and 1990-93 conditions. The slope-area peak discharge $\left(5,670 \mathrm{ft}^{3} / \mathrm{s}\right)$ recorded at site 21 on February 25, 1969, was not used in the calibration of the 1970-75 model, but a comparison was made of the measured and simulated peak discharge for that day. On that day, the 1970-75 model-simulated peak discharge was $5,224 \mathrm{ft}^{3} / \mathrm{s}$, for a simulation error in peak discharge of about 8 percent.

The statistical analysis of the annual peak discharges (table 26, at back of report) indicates the maximum peak discharge increased about 15 percent at basins 15 and 17 and about 30 percent at basins 9 and 21 , whereas the average annual peak discharge increased about 60 percent at basins 9,15 , and 21 and about 8 percent at basin 17 . The annual peak discharge at basin 17 was only slightly greater for the 1990-93 conditions, likely because of the relatively small increase of 8 percent in noneffective impervious area in the 1990-93 model.

The plots of the simulated annual volumes of the two models (fig. 19, at back of report) indicate a consistently greater volume for the 1990-93 conditions at basins 9,15 , and 21 . Basin 17 indicates only a slightly greater annual volume for the 1990-93 conditions. The statistical analysis for the annual runoff volumes (table 27, at back of report) also reflect the same pattern. The maximum and average annual volumes at basins 9,15 , and 21 were about 60 to 90 percent higher during the 1990-93 simulation. The maximum and average annual volume at basin 17 was about 20 percent higher during the 1990-93 simulation.

Analysis of the simulated storm peak discharges (table 28, at back of report) indicated that the average storm peaks at basins 9,15 , and 21 increased about 115 to 130 percent between the 1970-75 and 1990-93 conditions. Again, the calibrated models at basin 17 indicated a relatively small 12 -percent increase in the average storm peak discharge between the 1970-75 and 1990-93 conditions. 
FREQUENCY ANALYSIS OF LONG-TERM RAINFALL AND SIMULATED ANNUAL PEAK DISCHARGES AND RUNOFF VOLUMES

\section{ANNUAL PEAKS}

A Log-Pearson Type-III frequency analysis was calculated using the annual rainfall totals for 1949-93 and the simulated annual peak discharges and runoff volumes. The 2-, 5-, 10-, 25-, 50-, and 100-year recurrence intervals for the annual rainfall totals at the Riverside Citrus Experimental Station were 8.41, $12.58,15.62,19.74,23.05$, and 26.48 in., respectively. Plots comparing the flow characteristics for annual peak discharges and runoff volumes for the two models illustrate trends previously discussed. Simulated annual peak discharges (fig. 20, at back of report) for the two models at basins 9,15 , and 21 differ by about 100 percent at the 2-year recurrence interval, then converge between the 50-year and 100-year recurrence intervals. The estimated 100-year peak discharge for each model is about $1,900 \mathrm{ft}^{3} / \mathrm{s}$ at basin 9 , about 8,500 $\mathrm{ft}^{3} / \mathrm{s}$ at basin 15 , and about $14,000 \mathrm{ft}^{3} / \mathrm{s}$ at basin 21 . Annual peak discharge at basin 17 (fig. 20) diverges as the peaks increase. The estimated 100-year peak discharge at basin 17 is about $850 \mathrm{ft}^{3} / \mathrm{s}$ for the 1970-75 conditions and about $1,050 \mathrm{ft}^{3} / \mathrm{s}$ for the $1990-93$ conditions.

\section{REGIONAL COMPARISON}

A regional frequency analysis (Waananen and Crippen, 1977) of annual flood peak discharges was calculated for each basin and study period to compare with the model frequency analysis (Log-Pearson TypeIII) of simulated annual peak discharges. The regional frequency analysis uses regression equations to calculate flood magnitudes of selected frequencies from basin characteristics, such as drainage area and mean annual rainfall. The calculated discharges for each study period included adjustments for the percentage of basin developed and percentage of channels sewered. At basin 9, the 100-year peak discharge from the regional frequency analysis is 20 percent lower than that calculated from the model frequency analysis for the 1970-75 conditions and 9 percent lower for the 1990-93 conditions. At basin 15, the 100-year peak discharge from the regional frequency analysis is 48 percent lower than that calculated from the model frequency analysis for the 1970-75 conditions and 28 percent lower for the 1990 93 conditions. At basin 17, the 100-year peak discharge from the regional frequency analysis is 3 percent higher than that calculated from the model frequency analysis for the 1970-75,conditions and 1 percent higher for the 1990-93 conditions. At basin 21, the 100-year peak discharge from the regional frequency analysis is 51 percent lower than that calculated from the model frequency analysis for the 1970-75 conditions and 41 percent lower for the 199093 conditions. The errors (confidence limits) associated with the model frequency analysis of simulated annual peaks are considerably smaller. The model and regional frequency analyses of annual peak discharges are summarized in table 29 (at back of report).

\section{ANNUAL RUNOFF VOLUMES}

Similar to storm peaks, the frequency analyses of annual runoff volumes (fig. 21, at back of report) for basins 9,15 , and 21 indicate that the 2 -year recurrence volumes increase about 100 percent from 1970-75 conditions to $1990-93$ conditions, then converge as the recurrence interval increases. Annual runoff volumes at basin 17 diverge as the recurrence interval increases. Comparing all the basins, the 100 -year annual volumes were 34 to 48 percent higher during the 1990-93 conditions. Table 30 (at back of report) summarizes the Log-Pearson Type-III calculations for annual runoff volumes for selected recurrence intervals.

\section{DURATION ANALYSIS OF SIMULATED STORM RUNOFF PEAKS}

Duration analysis of the 925 simulated storm runoff peaks at each basin for the 1970-75 and 1990-93 conditions (fig. 22, at back of report) shows that the larger storm runoff peaks are very similar. At basin 9, the chances of exceeding $100 \mathrm{ft}^{3} / \mathrm{s}$ are 25 percent higher for flows representing the 1990-93 conditions. For storm runoff peaks greater than $1,000 \mathrm{ft}^{3} / \mathrm{s}$, the probabilities are identical. At basin 15, the chances of exceeding $100 \mathrm{ft}^{3} / \mathrm{s}$ are 28 percent higher for the 1990 93 conditions. For storm runoff peaks exceeding 2,500 $\mathrm{ft}^{3} / \mathrm{s}$, the probabilities are identical. At basin 17 , the storm runoff peaks for the 1970-75 and 1990-93 conditions are nearly identical. At basin 21 , the chances of exceeding $100 \mathrm{ft}^{3} / \mathrm{s}$ are 26 percent higher for 
the $1990-93$ conditions. For storm runoff peaks exceeding $2,500 \mathrm{ft}^{3} / \mathrm{s}$, the probabilities are identical.

\section{SUMMARY AND CONCLUSIONS}

Increased urbanization in Perris Valley, California, since the early 1970's has altered the drainage characteristics. Additional impervious areas have resulted in increased storm runoff volumes and peak discharges. The urban areas in Perris Valley have more than tripled during the last 20 years. The basin has increased from about 10 percent urban area in the early 1970's to more than 36 percent in the early 1990 's. To quantify the hydrologic effects of increased urbanization, the U.S. Geological Survey Distributed Routing Rainfall-Runoff Model (DR3M-II) was applied to four subbasins, each calibrated from data collected during 1970-75 and 1990-93. For the 197075 model, the average calibration errors for the four basins were 36 percent for runoff volumes and 29 percent for peak discharges. The average calibration errors for the 1990-93 model were 27 percent for runoff volumes and 34 percent for peak discharges; verification errors were 35 percent for runoff volumes and 43 percent for peak discharges.

Hourly rainfall data for 1949-93 were used with the rainfall-runoff models to simulate a long-term record of storm runoff. The hydrologic effects of increased urbanization from $1970-75$ to $1990-93$ were analyzed by comparing the simulated annual peak discharges and volumes and storm runoff peaks, frequency of annual peak discharges and runoff volumes, and duration of storm peak discharges for each study period.

From 1970-75 to $1990-93$ conditions, the maximum annual peak discharge increased about 15 percent at basins 15 and 17 and about 30 percent at basins 9 and 21 . The average annual storm peak, however, increased about 60 percent at basins 9,15 , and 21 and about 8 percent at basin 17. The maximum and average annual volumes at basins 9,15 , and 21 were about 60 to 90 percent higher during the 1990-93 simulations. At basin 17, the maximum and average annual volume was about 20 percent higher during the 1990-93 simulation. When all the simulated storm peaks are included, the average storm peaks at basins 9 , 15 , and 21 increased about 115 to 130 percent between the 1970-75 and 1990-93 conditions. At basin 17, the average storm peak increased about 12 percent between the 1970-75 and 1990-93 conditions

A Log-Pearson Type-III frequency analysis was calculated for the two study periods using the simulated annual peak discharges and runoff volumes.
Simulated annual peak discharges for the two models at basins 9,15 , and 21 differ by about 100 percent at the 2-year recurrence interval, then converge between the 50 - and 100-year recurrence intervals. The estimated 100 -year peak discharge for each model is about 1,900 $\mathrm{ft}^{3} / \mathrm{s}$ at basin 9 , about $8,500 \mathrm{ft}^{3} / \mathrm{s}$ at basin 15 , and about $14,000 \mathrm{ft}^{3} / \mathrm{s}$ at basin 21 . At basin 17 , annual peak discharges slightly diverge. The estimated 100 -year peak discharge at basin 17 is about $850 \mathrm{ft}^{3} / \mathrm{s}$ for the $1970-75$ conditions and about $1,050 \mathrm{ft}^{3} / \mathrm{s}$ for the $1990-93$ conditions. For the 2-year recurrence interval, annual runoff volumes were similar to the peak discharge analysis. However, the 100-year annual volumes were 34 to 48 percent higher during the $1990-93$ conditions. A regional frequency analysis of annual flood peak discharges was calculated for each basin and study period and compared with the frequency analysis of the model-simulated annual peak discharges. For the $1970-75$ conditions, the regional 100-year peaks ranged from 3 percent higher at basin 17 to 51 percent lower at basin 21. For the 1990-93 conditions, the regional 100-year peaks ranged from 1 percent higher at basin 17 to 41 percent lower at basin 21 . The comparison indicates that, the smaller the basin, the closer the regional frequency analysis compares with the model frequency analysis.

The 1970-75 and 1990-93 flow characteristics for annual runoff volumes at basins 9,15 , and 21 differ by about 100 percent at the 2 -year recurrence interval, then converge as the recurrence interval decreases. Annual peaks at basin 17 diverge as the recurrence interval increases. The 100 -year annual volumes were 34 to 48 percent higher during the $1990-93$ conditions.

The duration analysis of the simulated storm peaks indicated that the larger low-frequency storms for the two models are similar. There is less than a 1percent higher chance of exceeding flows of $1,000 \mathrm{ft}^{3} / \mathrm{s}$ at basin $9 ; 2,500 \mathrm{ft}^{3} / \mathrm{s}$ at basin $15 ; 500 \mathrm{ft}^{3} / \mathrm{s}$ at basin 17; and 2,500 $\mathrm{ft}^{3} / \mathrm{s}$ at basin 21 for the 1990-93 conditions.

The modeling effort and subsequent analysis of the simulated data indicate that changes in annual peak discharges from the 1970-75 to 1990-93 urbanized conditions were significant for the small, frequent storms, but not for the large, infrequent storms because runoff from small storms is primarily generated from impervious urban areas. The 2-year peaks at the outlet of the basin more than doubled from 1970-75 to 199093 because the basin's impervious areas increased from 8 to 22 percent. However, the peaks with recurrence intervals greater than 50 years were not significantly affected by the changes in urbanization because saturated pervious areas associated with large, infrequent storms produce runoff peaks approaching 
those found on impervious surfaces. The annual runoff volumes were affected by the changes in urbanization because annual volumes represent a mixture of flow regimes ranging from impervious only flows to flows where the basin is fully saturated.

\section{REFERENCES CITED}

Alley, W.M., Dawdy, D.R., and Schaake, J.C., Jr., 1980, Parametric-deterministic urban watershed model: American Society of Civil Engineers, Journal of the Hydraulics Division, v. 106, no. HY5, p. 679-690.

Alley, W.M., and Smith, P.E., 1982, Distributed routing rainfall-runoff model--version II; Computer program documentation, users's manual: U.S. Geological Survey Open-File Report 82-344, 201 p.

Dawdy, D.R., Lichty, R.W., and Bergmann, J.M., 1972, A rainfall-runoff simulation model for estimation of flood peaks for small drainage basins: U.S. Geological Survey Professional Paper 506-B, 28 p.

Dawdy, D.R., Schaake, J.C., Jr., and Alley, W.M., 1978, User's guide for distributed routing rainfall-runoff model: U.S. Geological Survey Water-Resources Investigations 78-90, $146 \mathrm{p}$.

Durbin, T.J., 1974, Digital simulation of the effects of urbanization on runoff in the upper Santa Ana Valley, California: U.S. Geological Survey Water-Resources Investigations 41-73, $44 \mathrm{p}$.

Fulton, J.L., 1990, Application of a distributed-routing rainfall-runoff model to flood-frequency estimation in Somerset County, New Jersey: U.S. Geological Survey Water-Resources Investigations Report 89-4210, $78 \mathrm{p}$.

Green, W.H., and Ampt, G.A., 1911, Studies on soil physics; I, flow of air and water through soils: Journal of Agricultural Science, v. 4, p. 1-24.

Guay, J.R., and Smith, P.E., 1988, Simulation of quantity and quality of storm runoff for urban catchments in Fresno, California: U.S. Geological Survey WaterResources Investigations Report 88-4125, 76 p.

Knecht, A.A., 1971, Soil survey of western Riverside area, California: U.S. Departments of Agriculture and Interior, $157 \mathrm{p}$.

Lang, D.J., 1979, Water-resources data, 1970-75, for Perris Valley and vicinity, Riverside County, California: U.S. Geological Survey Open-File Report 79-1256, $127 \mathrm{p}$.

LeClerc, Guy, and Schaake, J.C., 1973, Methodology for assessing the potential impact of urban development on urban runoff and the relative efficiency of runoff control alternatives: Massachusetts Institute of Technology, Ralph M. Parsons Laboratory, Report no. 167, $257 \mathrm{p}$.
Lindskov, K.L., and Thompson, K.R., 1989, Peak-flow characteristics of small urban drainage along the Wasatch Front, Utah: U.S. Geological Survey WaterResources Investigations Report, 89-4095, 38 p.

Lumb, A.M., and Kittle, J.L., 1985, ANNIE-interactive processing of data bases for hydrologic models: International Conference on Interactive Information and Processing Systems for Meteorology, Oceanography, and Hydrology, Los Angeles, California, January 1985, Proceedings.

Mitchell, W.B., Guptill, S.C., Anderson, K.E., Fegeas, R.G., and Hallam, C.A., 1977 [1978], GIRAS--A geographic information retrieval and analysis system for handling land use and land cover data: U.S. Geological Survey Professional Paper 1059, $16 \mathrm{p}$.

Prasad, S.N., and DeLeeuw, S.L., 1990, Development of agricultural sediment and transport model through streams and lakes: Water Resources Research Institute, Mississippi State University, 29 p.

Rosenbrock, H.H., 1960, An automatic method of finding the greatest or least value of a function: Computer Journal, v. 3, p. 175-184.

Sloto, R.A., 1988, Effects of urbanization on storm-runoff volume and peak discharge of Valley Creek, eastern Chester County, Pennsylvania: U.S. Geological Survey Water-Resources Investigations Report 87-4196, $32 \mathrm{p}$.

Smith, P.E., and Alley, W.H., 1982, Rainfall-runoff quality model for urban watersheds: International Symposium on Rainfall-Runoff Modeling, Mississippi State University, May 18-21, 1981, p. 421-442.

Thomas, R.P., 1990, Application of the DR3M watershed model on a small urban basin: Water Resources Bulletin, v. 26, no. 5, p. 757-766.

Troxell, H.C., 1948, Hydrology of western Riverside County, California: Riverside County Flood Control and Water Conservation District, $111 \mathrm{p}$.

U.S. Soil Conservation Service, 1975, Soil taxonomy--A basic system of soil classification for making and interpreting soil surveys: U.S. Soil Conservation Service, Agriculture Handbook 436, 754 p.

Waananen, A.O., and Crippen, J.R., 1977, Magnitude and frequency of floods in California: U.S. Geological Survey Water-Resources Investigations 77-21, 96 p.

Weiss, L.A., 1990, Effects of urbanization on peak streamflows in four Connecticut communities: U.S. Geological Survey Water-Resources Investigations Report 89$4167,40 \mathrm{p}$. 
FIGURES 2-22 


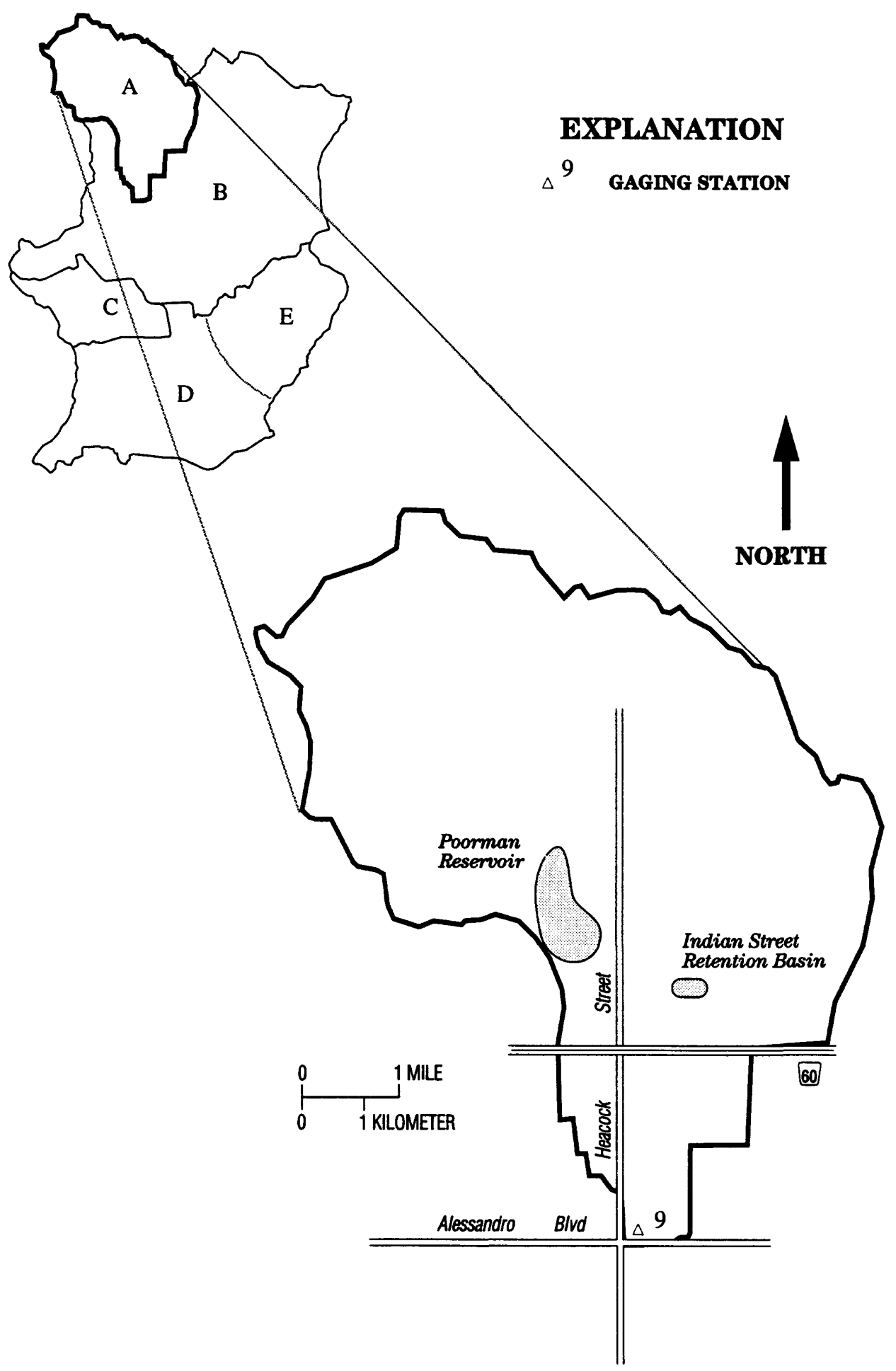

Figure 2. Location of basin 9, Perris Valley, California. 


\section{EXPLANATION}

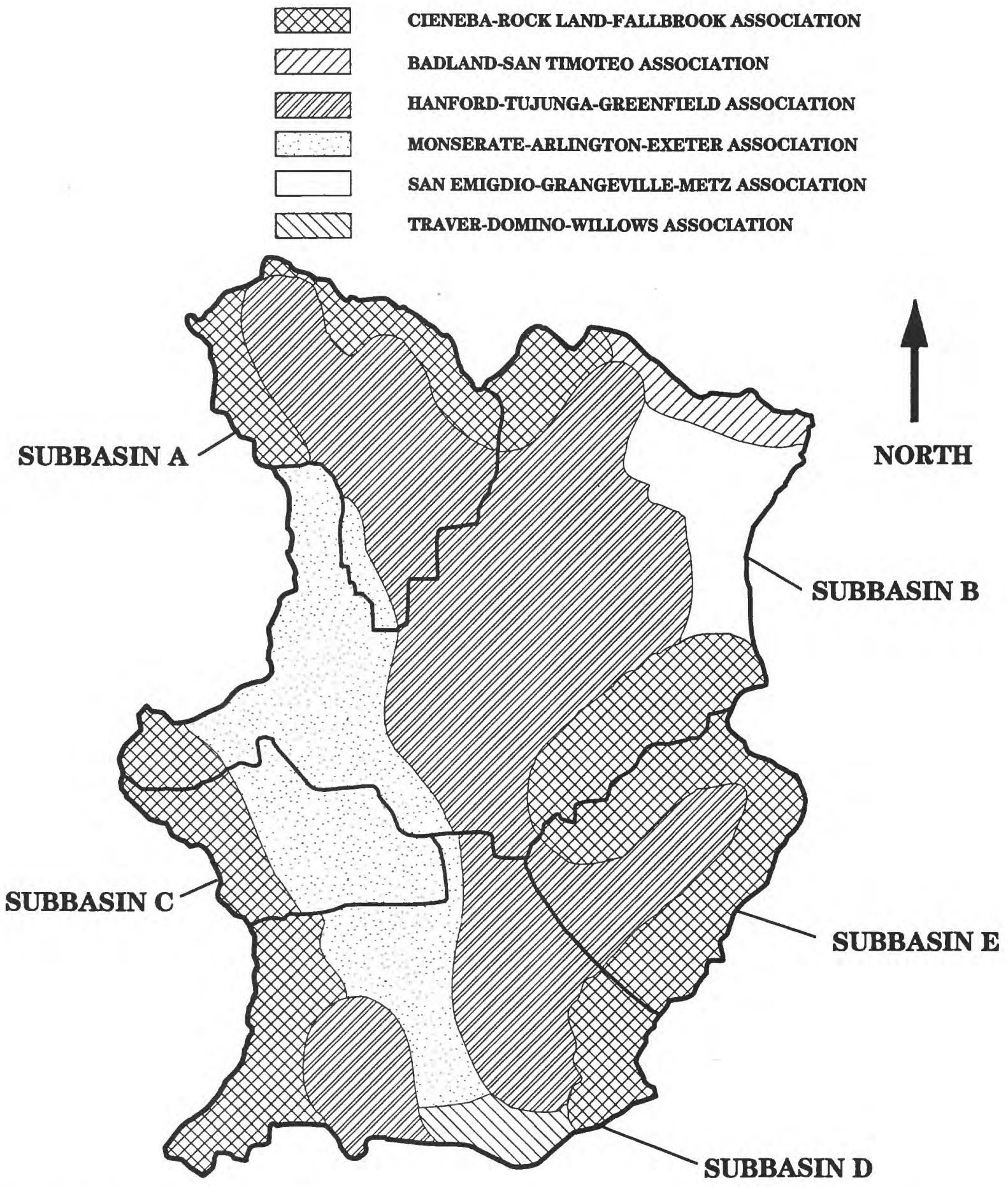

Figure 3. Soil types for Perris Valley, California (modified from general soil map, Knecht, 1971). 


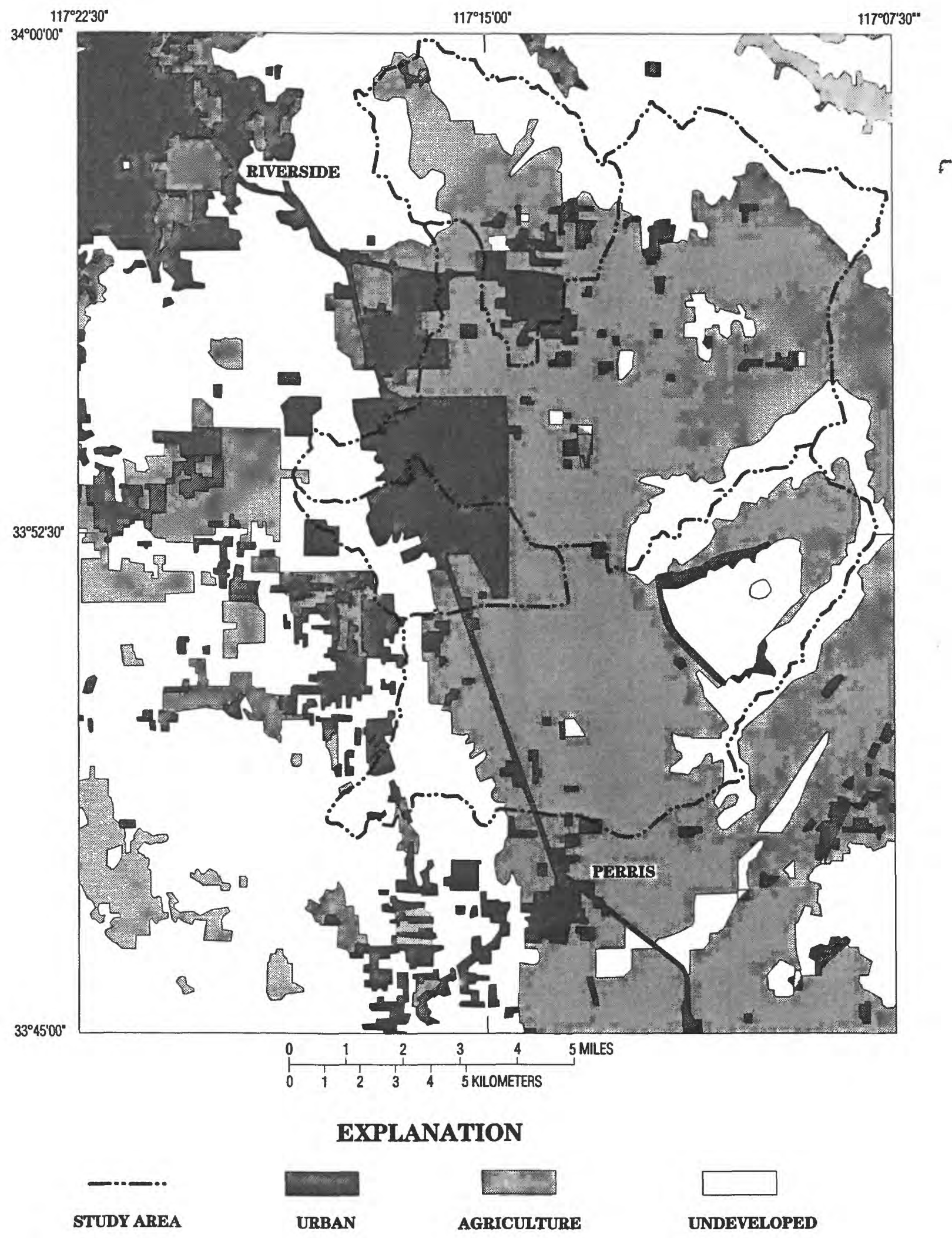

Figure 4. Land use in Perris Valley, California, 1972-75 (modified from GIRAS data, Mitchell and others, 1977). 


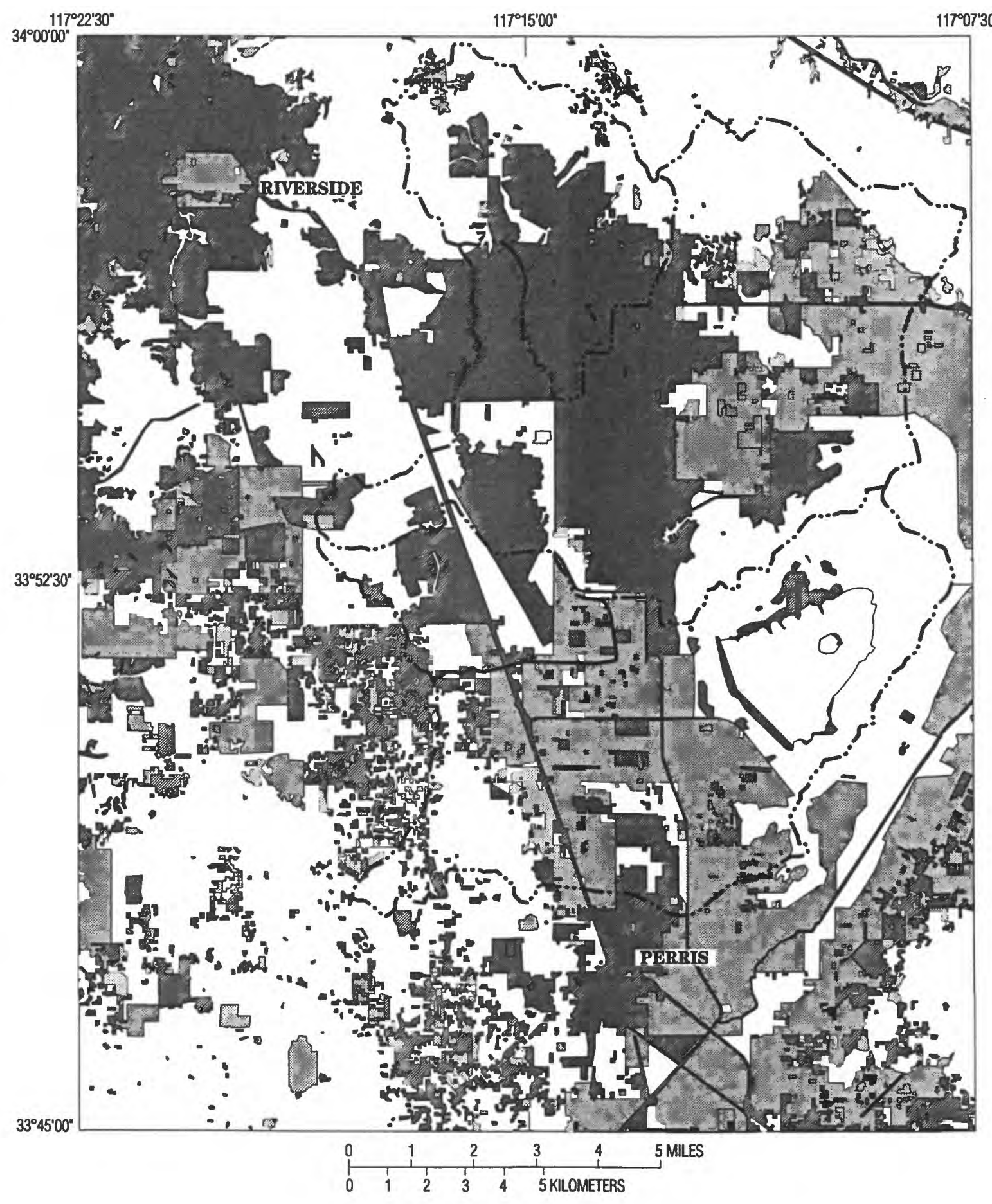

\section{EXPLANATION}

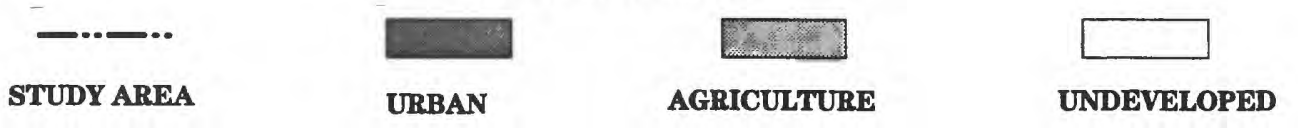

Figure 5. Land use in Perris Valley, California, 1990 (modified from digital land-use information provided by Southern California Association of Governments). 


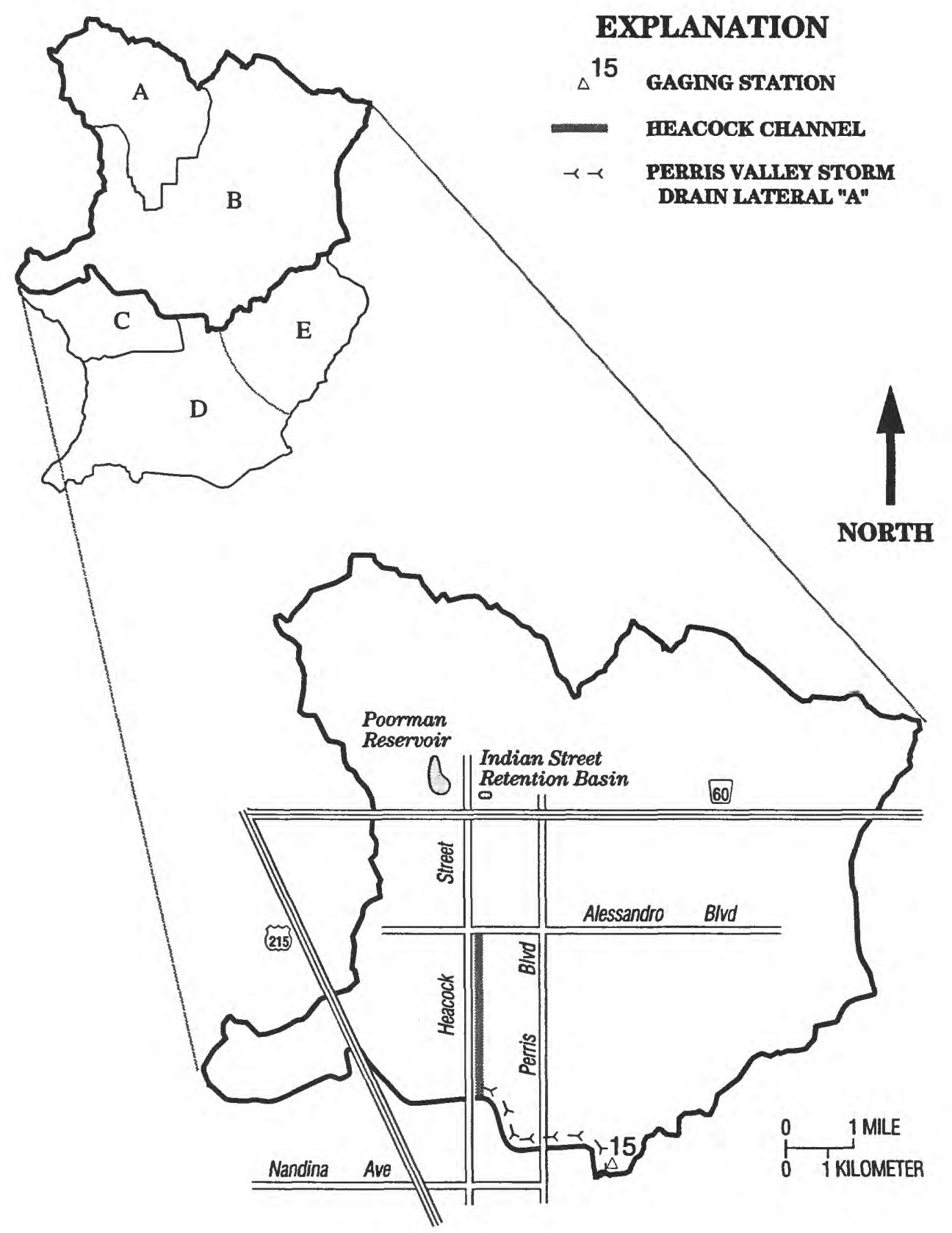

Figure 6. Location of basin 15, Perris Valley, California. 


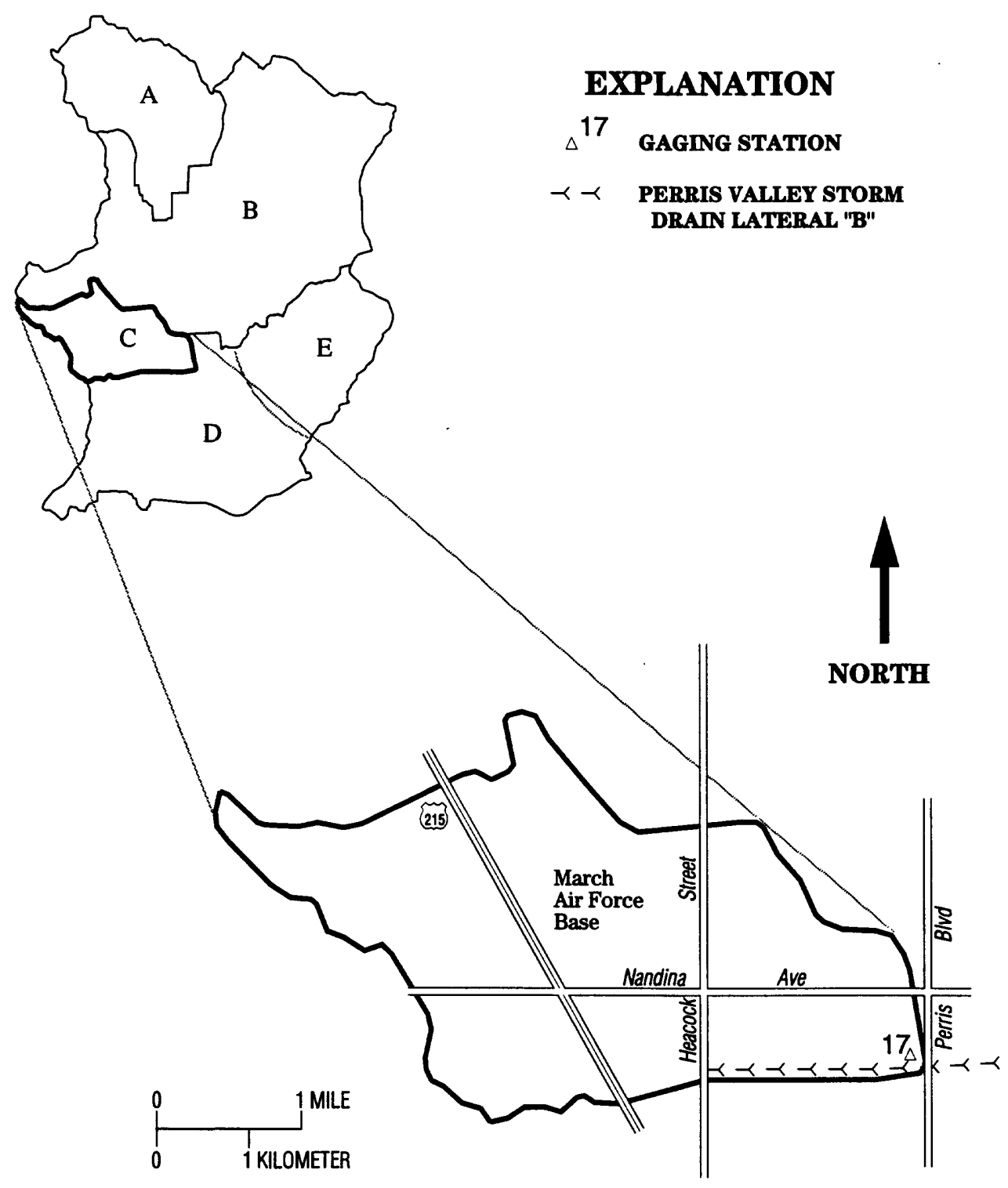

Figure 7. Location of basin 17, Perris Valley, California. 


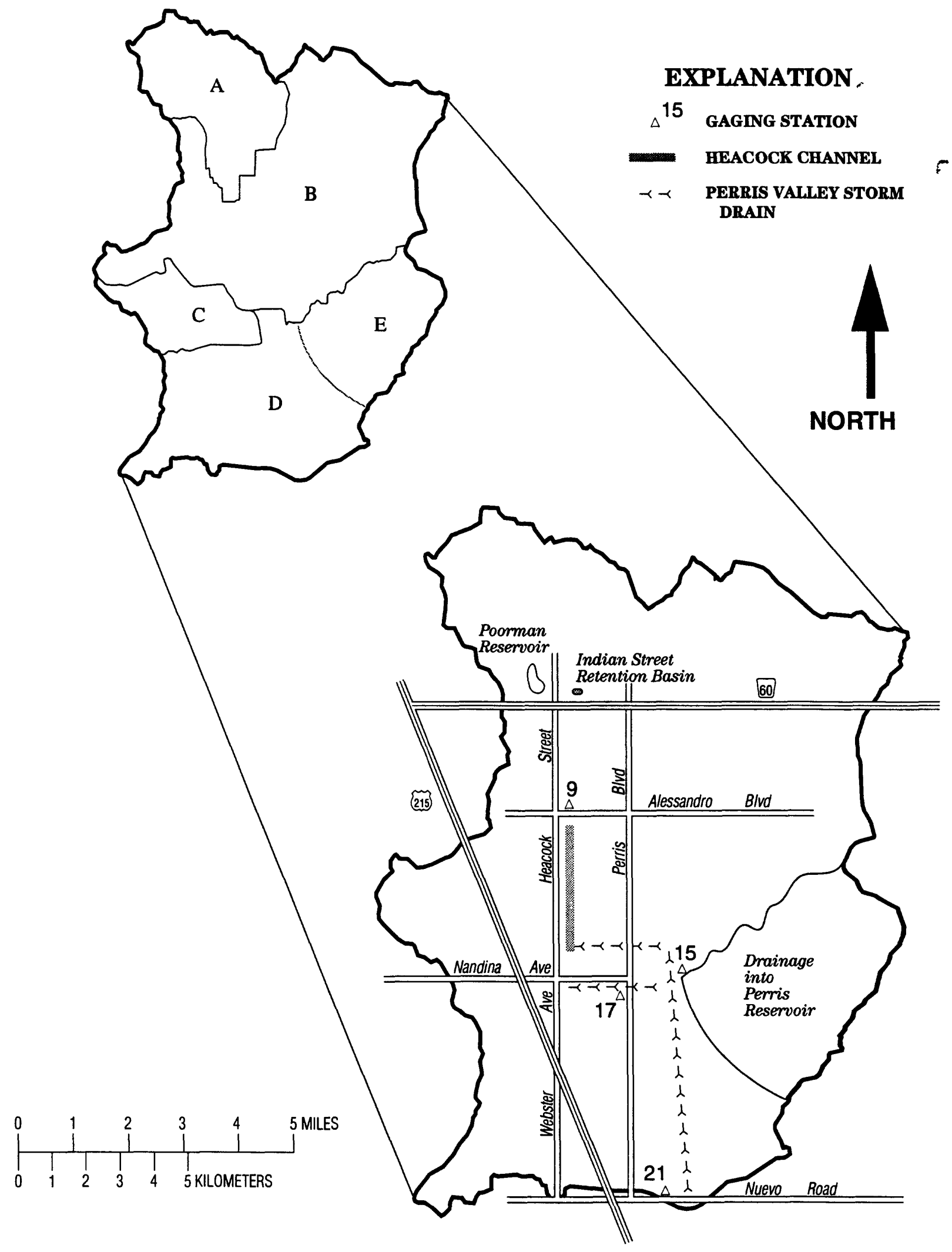

Figure 8. Location of basin 21, Perris Valley, California. 


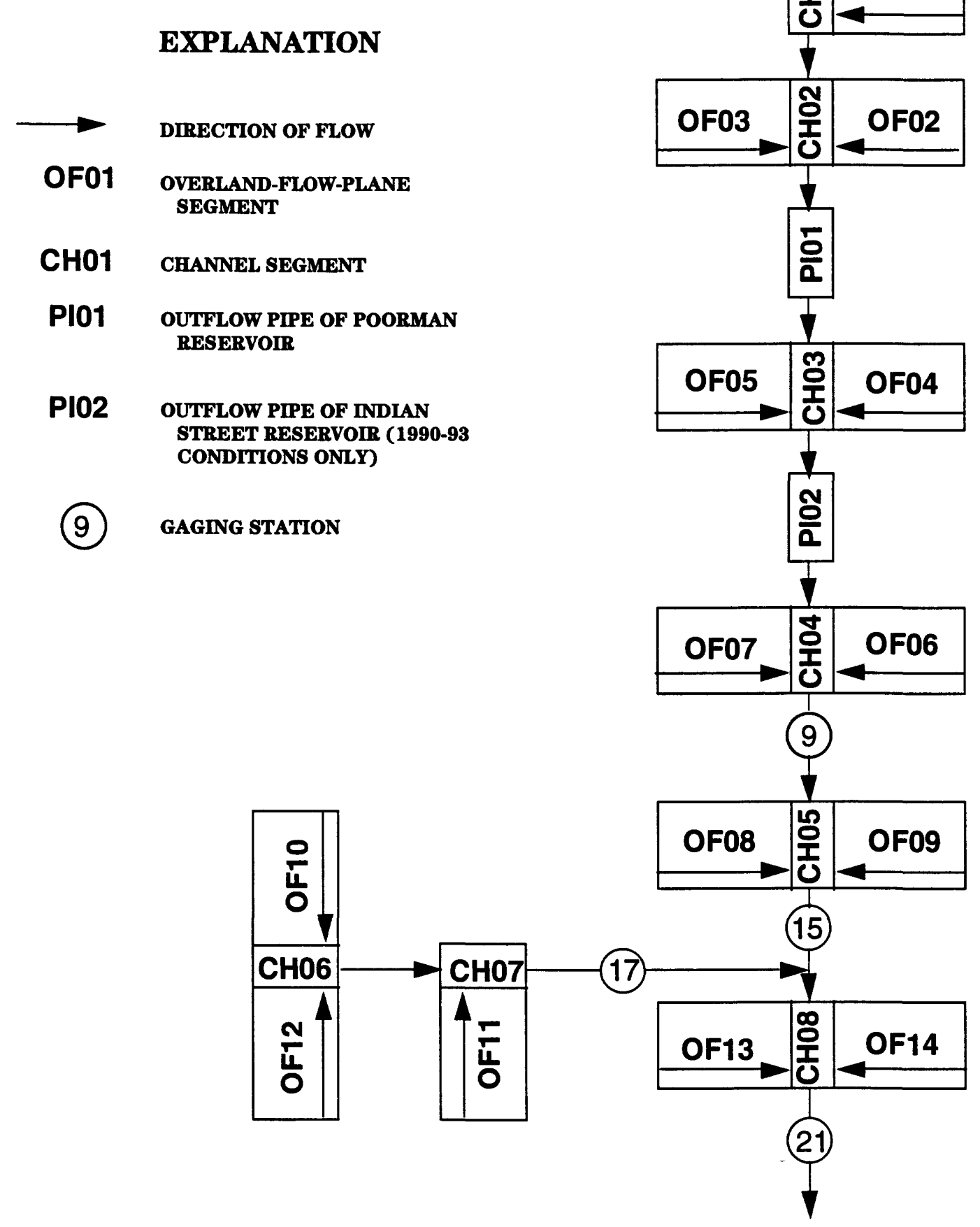

Figure 9. Schematization of the 1970-75 and 1990-93 rainfall-runoff models. 

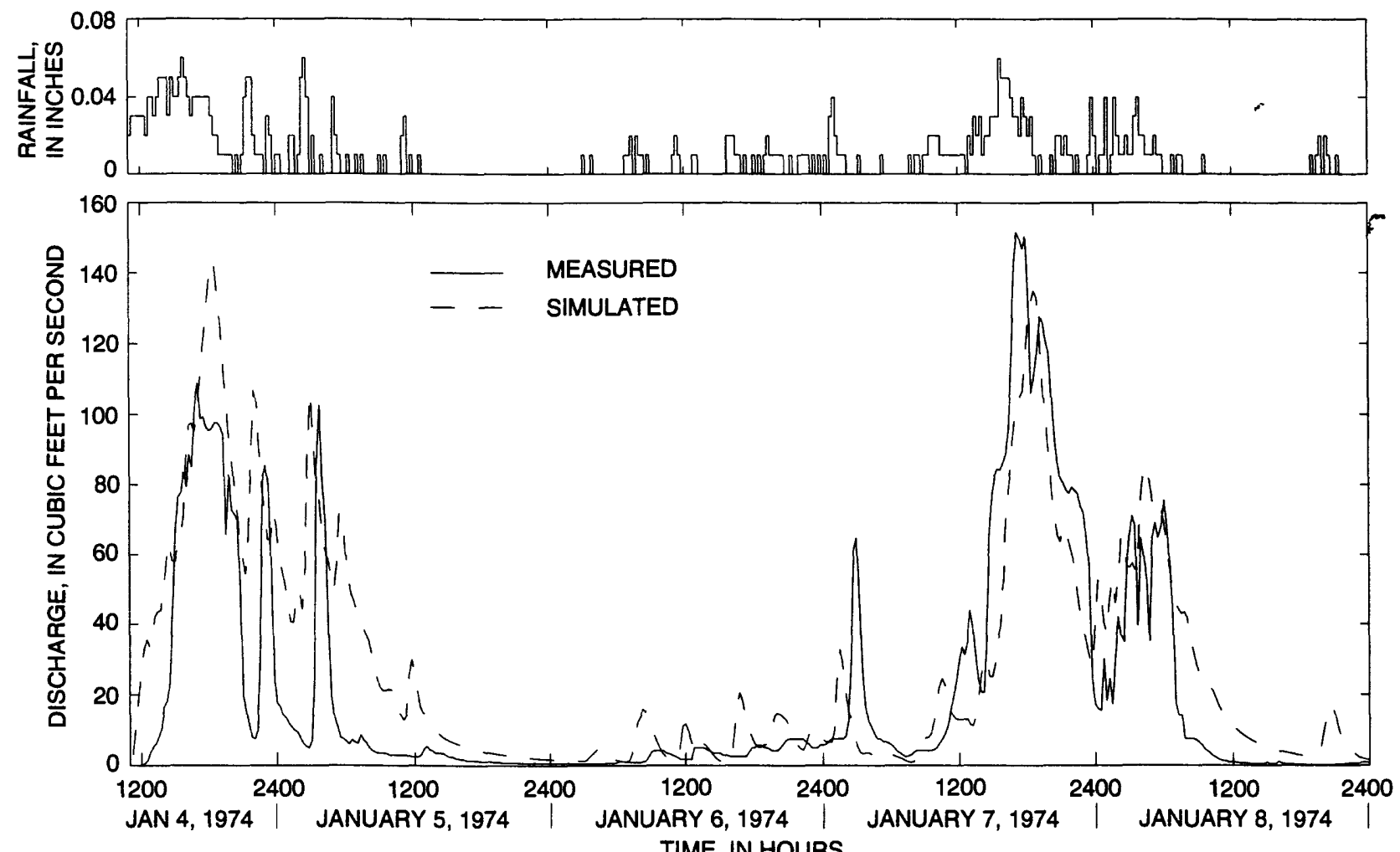

Figure 10. Measured and simulated discharge for a selected storm used to calibrate the 1970-75 rainfallrunoff model at basin 9, Perris Valley, California. 

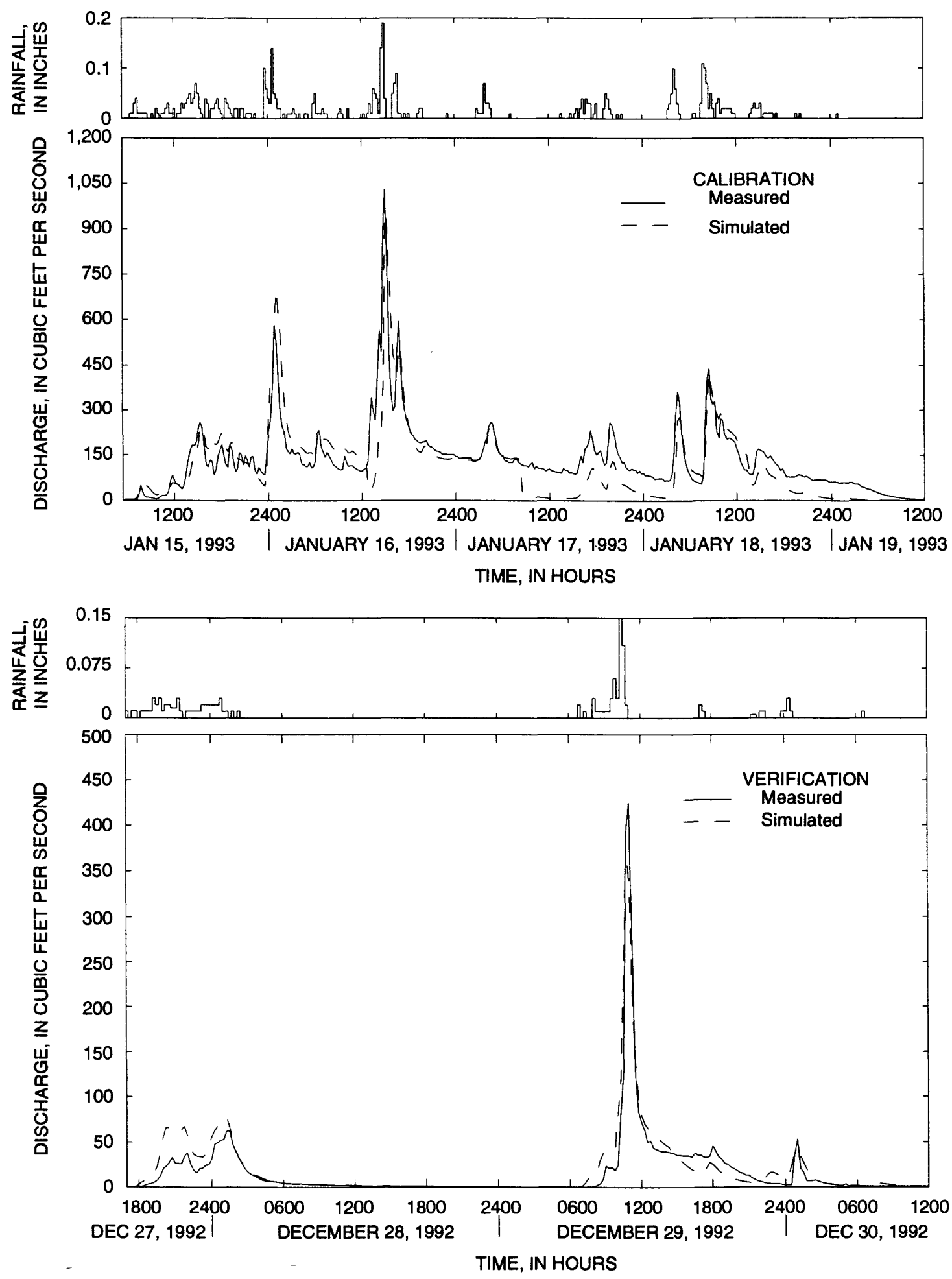

Figure 11. Measured and simulated discharge for two selected storms used to calibrate and verify the 1990-93 rainfall-runoff model at basin 9, Perris Valley, California. 

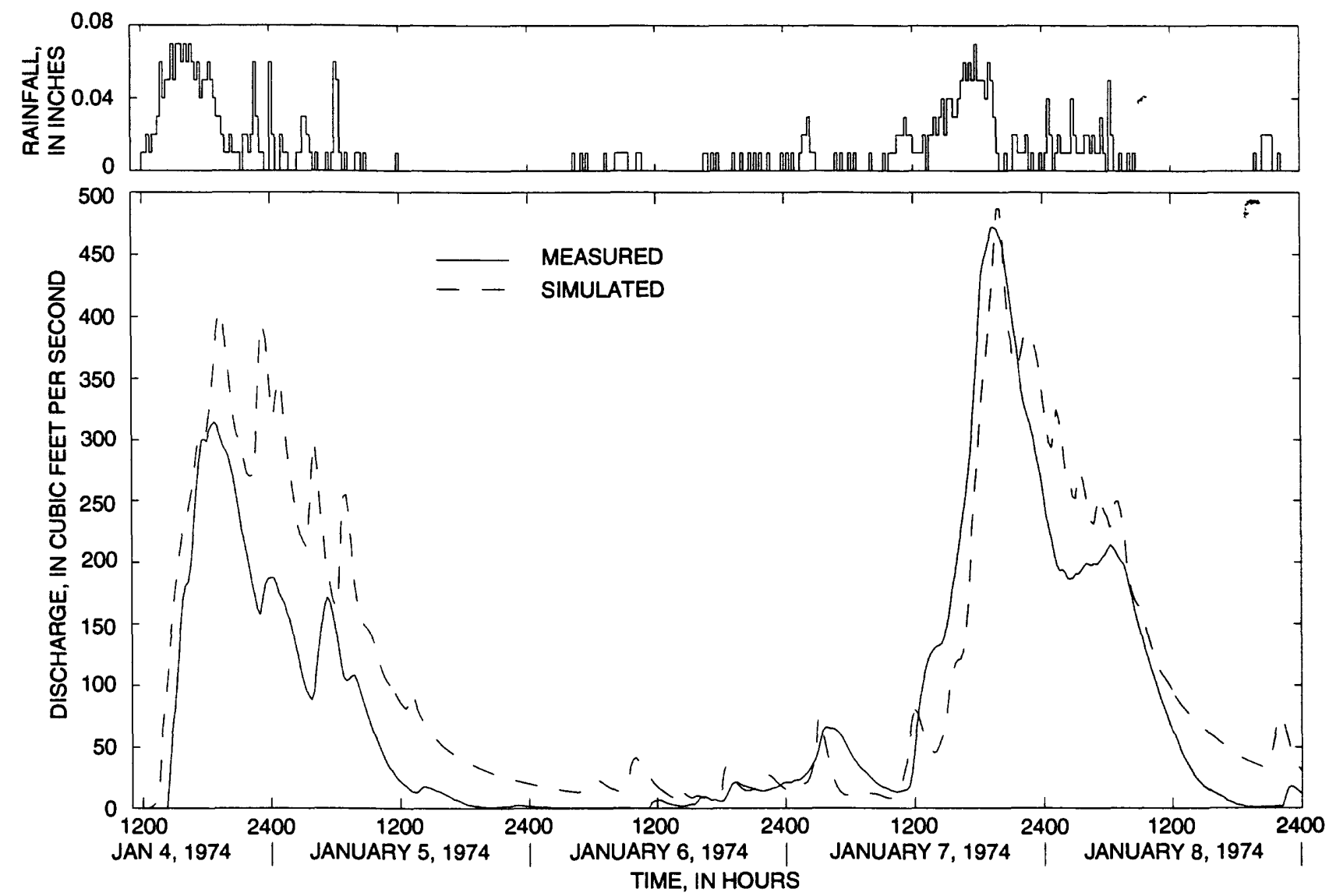

Figure 12. Measured and simulated discharge for a selected storm used to calibrate the 1970-75 rainfall-runoff model at basin 15 , Perris Valley, California. 


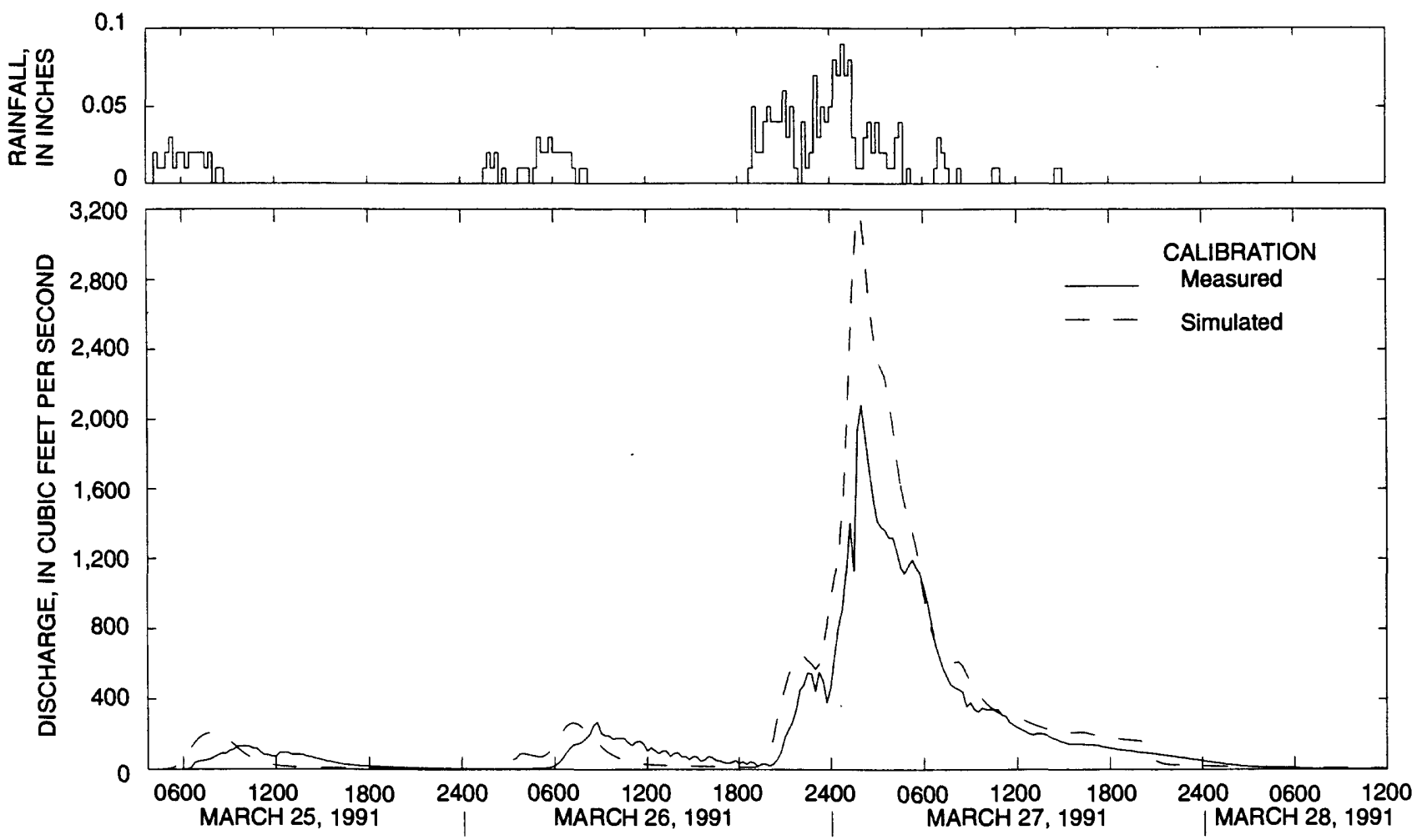

TIME, IN HOURS
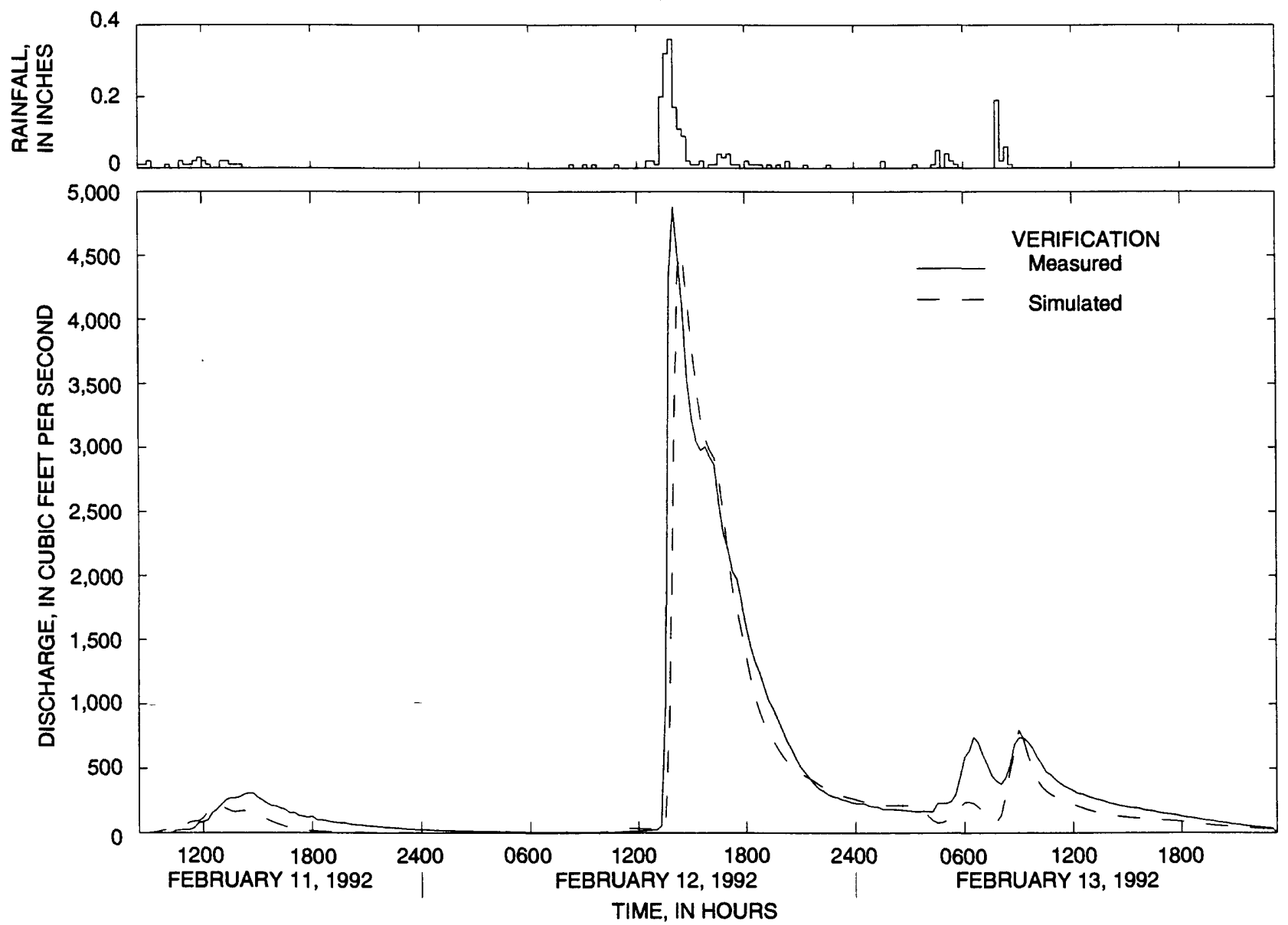

Figure 13. Measured and simulated discharge for two selected storms used to calibrate and verify the 1990-93 rainfall-runoff model at basin 15 , Perris Valley, California. 

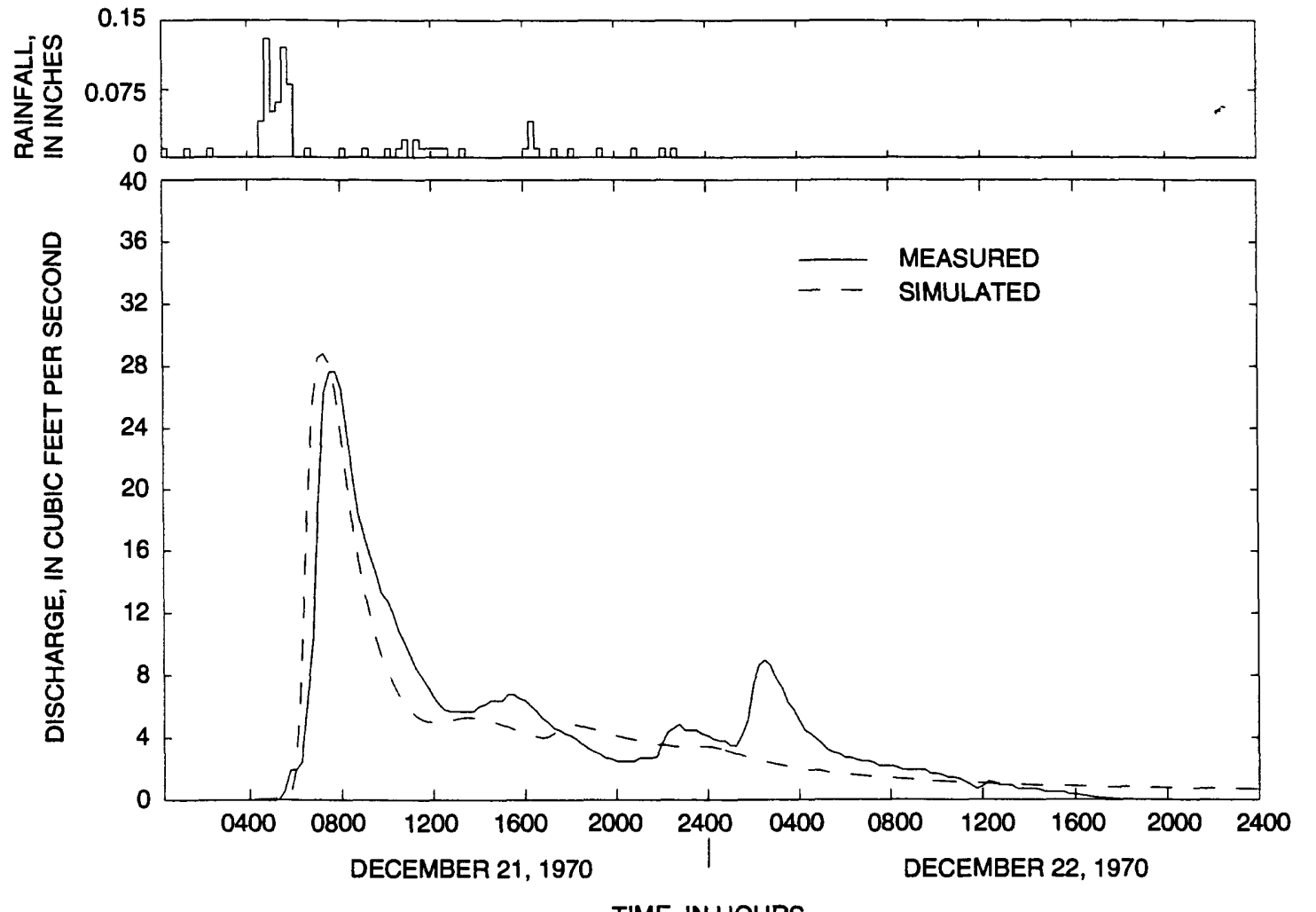

TIME, IN HOURS

Figure 14. Measured and simulated discharge for a selected storm used to calibrate the 197075 rainfall-runoff model at basin 17 , Perris Valley, California. 


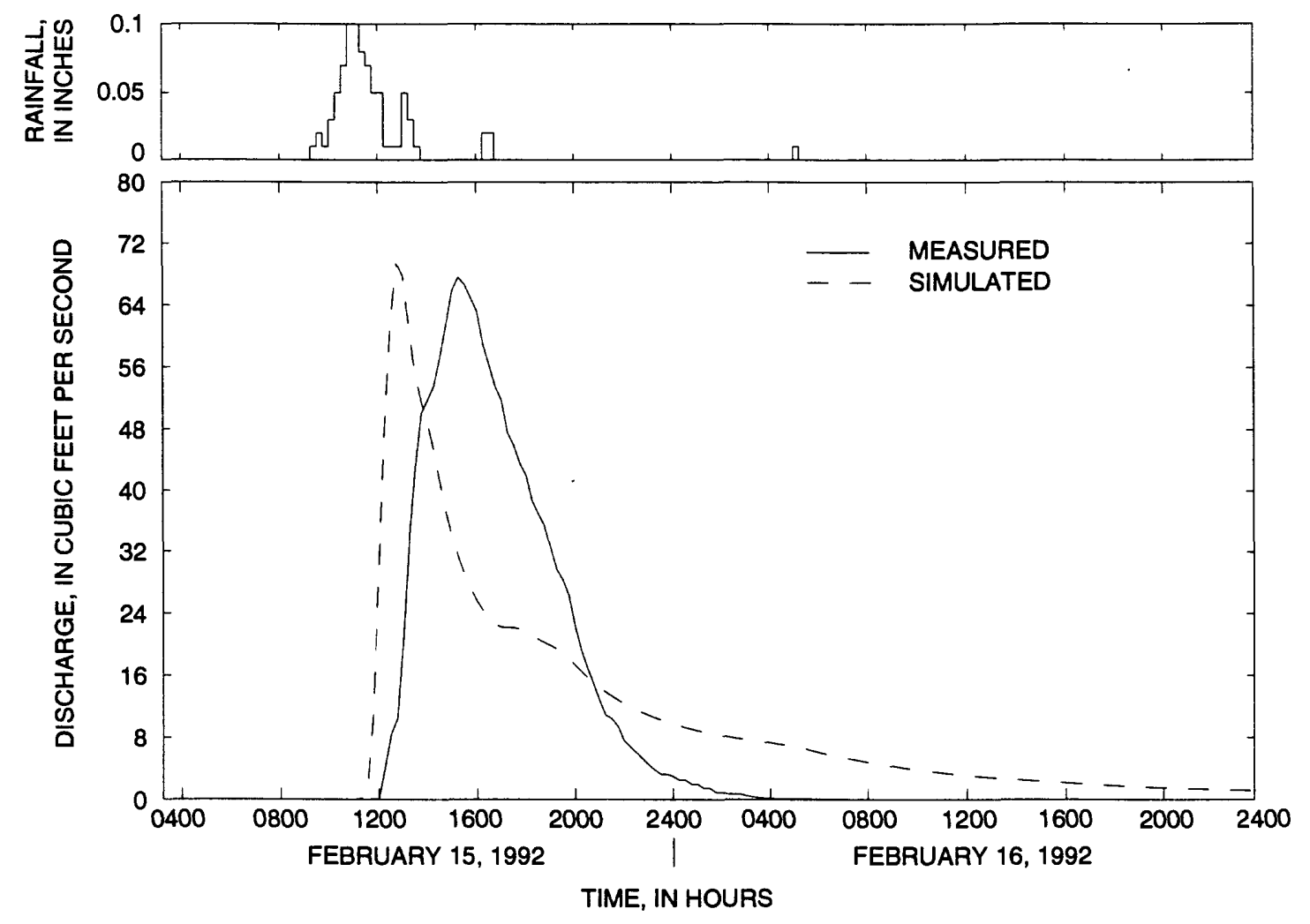

Figure 15. Measured and simulated discharge for a selected storm used to calibrate the 199093 rainfall-runoff model at basin 17, Perris Valley, California

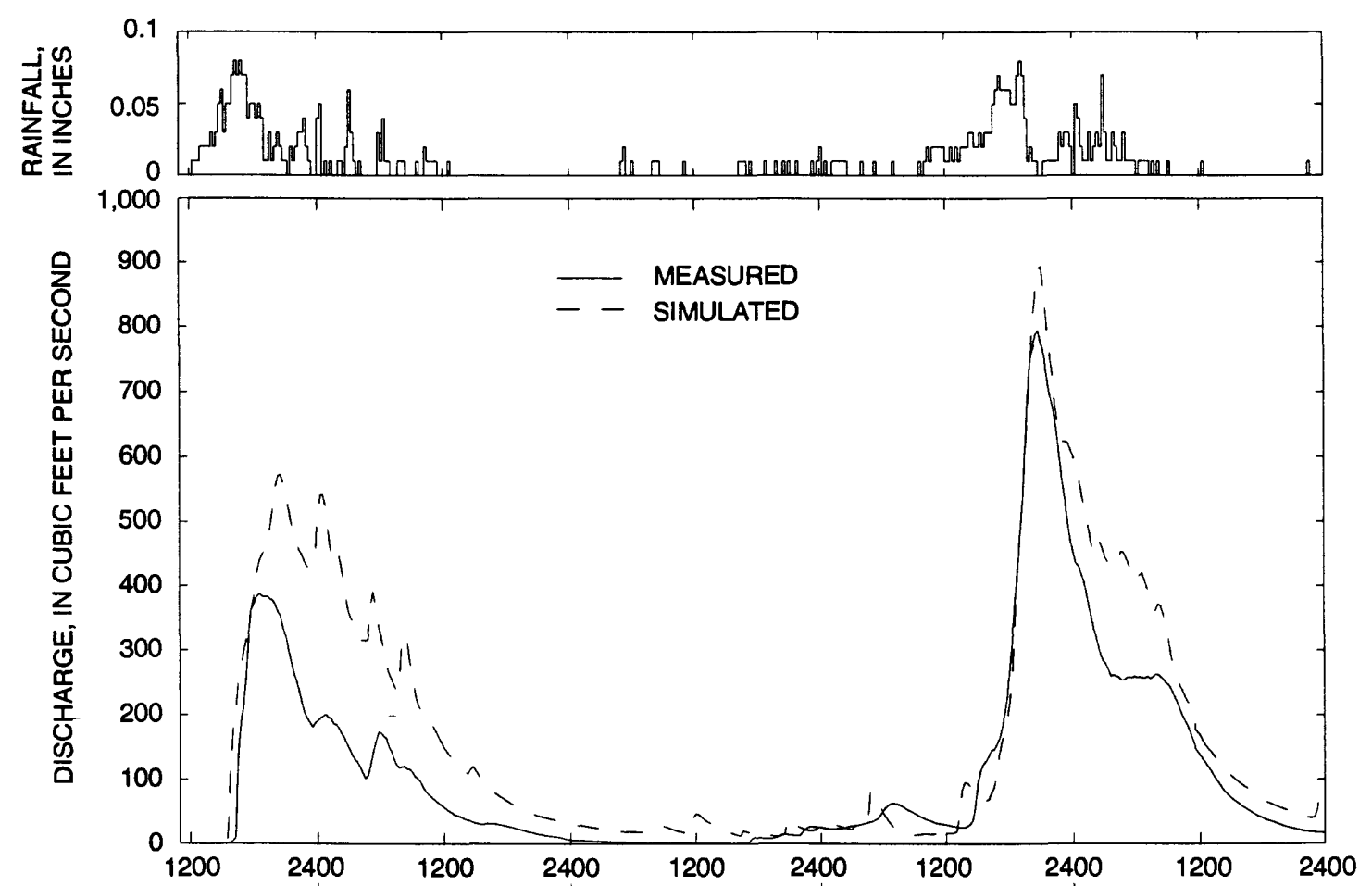

JANUARY 4, 1974 | JANUARY 5, 1974 | JANUARY 6, 1974 | JANUARY 7, 1974 | JANUARY 8, 1974

TIME, IN HOURS

Figure 16. Measured and simulated discharge for a selected storm used to calibrate the 197075 rainfall-runoff model at basin 21 , Perris Valley, California. 


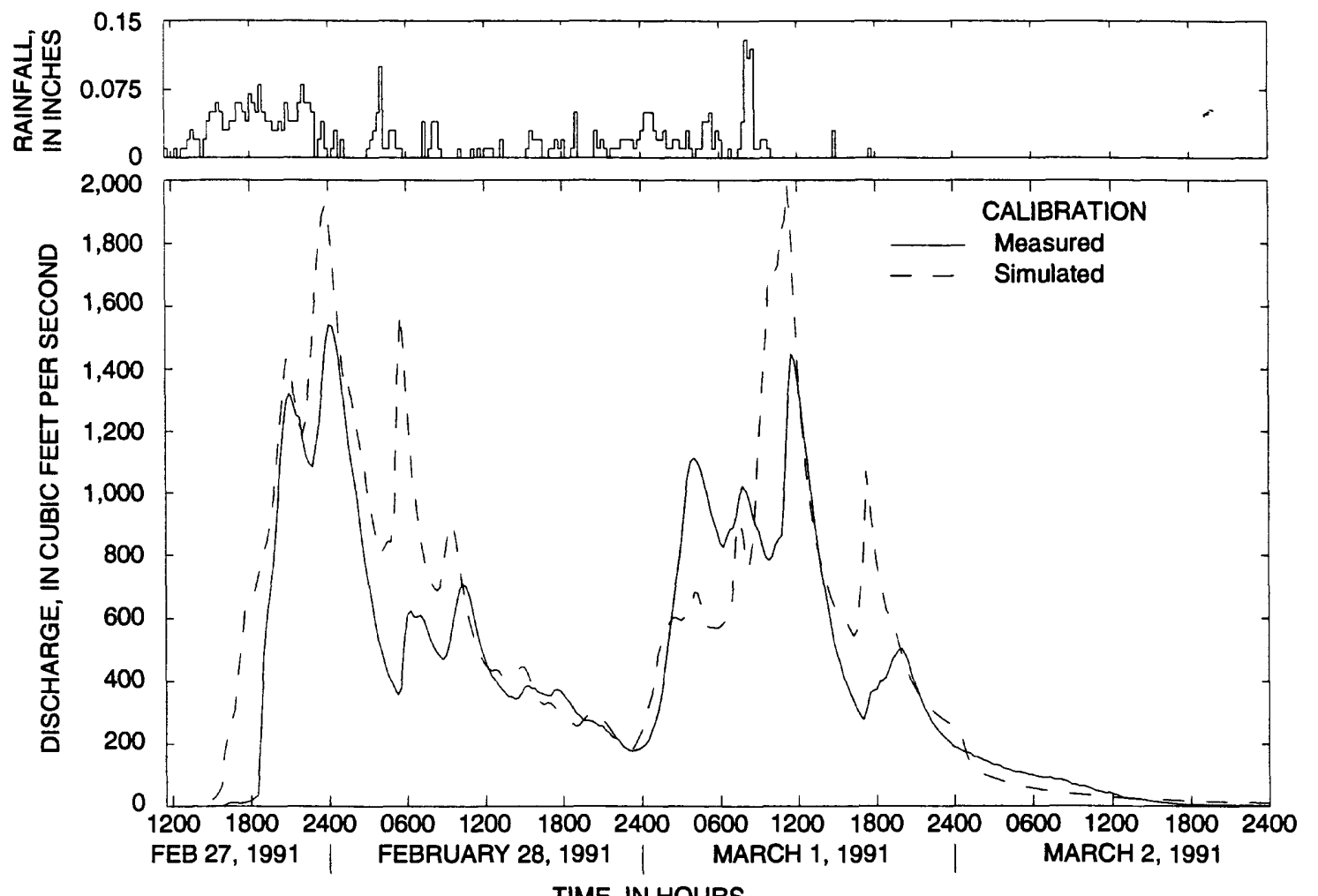

TIME, IN HOURS

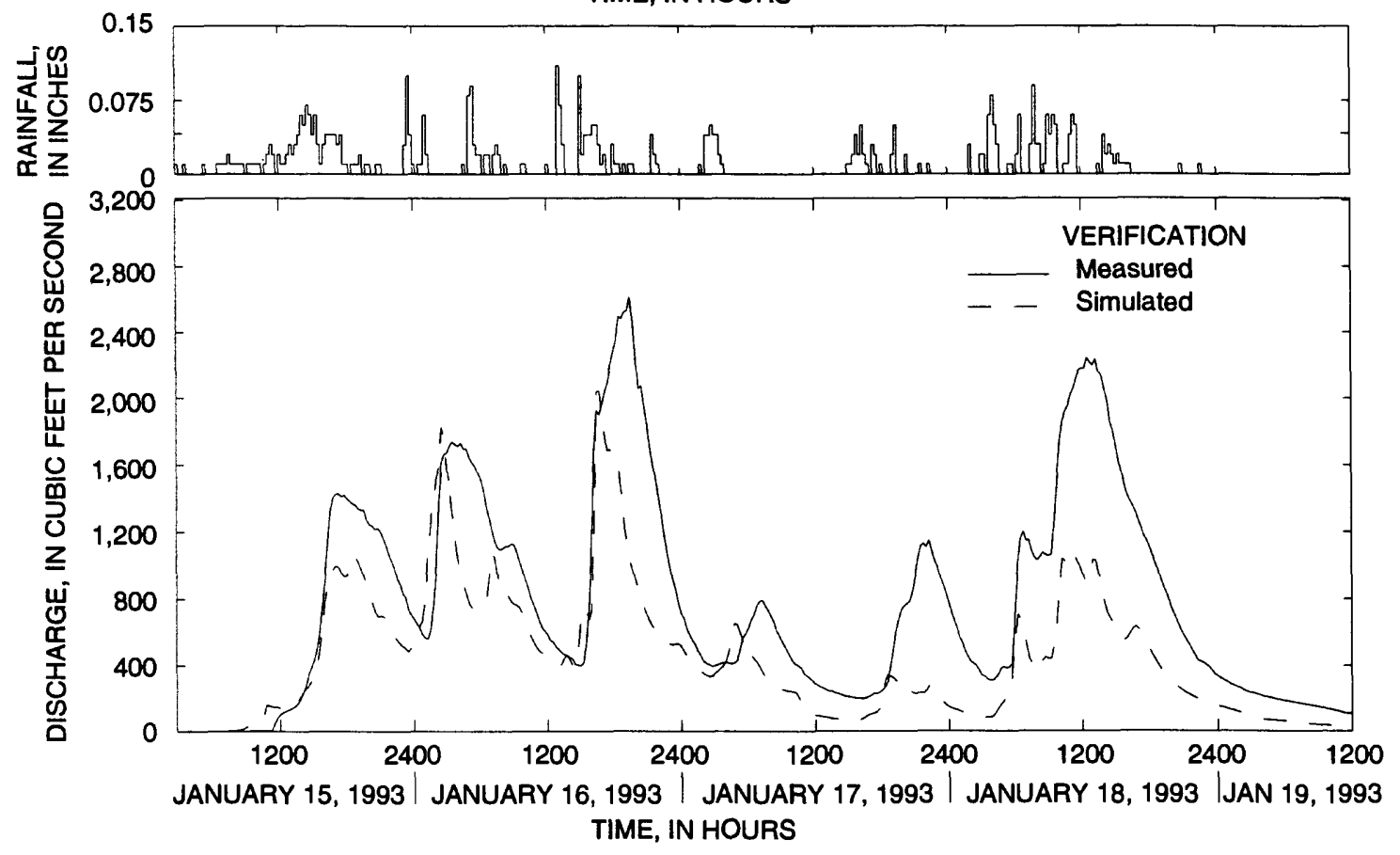

Figure 17. Measured and simulated discharge for two selected storms used to calibrate and verify the 1990-93 rainfall-runoff model at basin 21 , Perris Valley, California. 

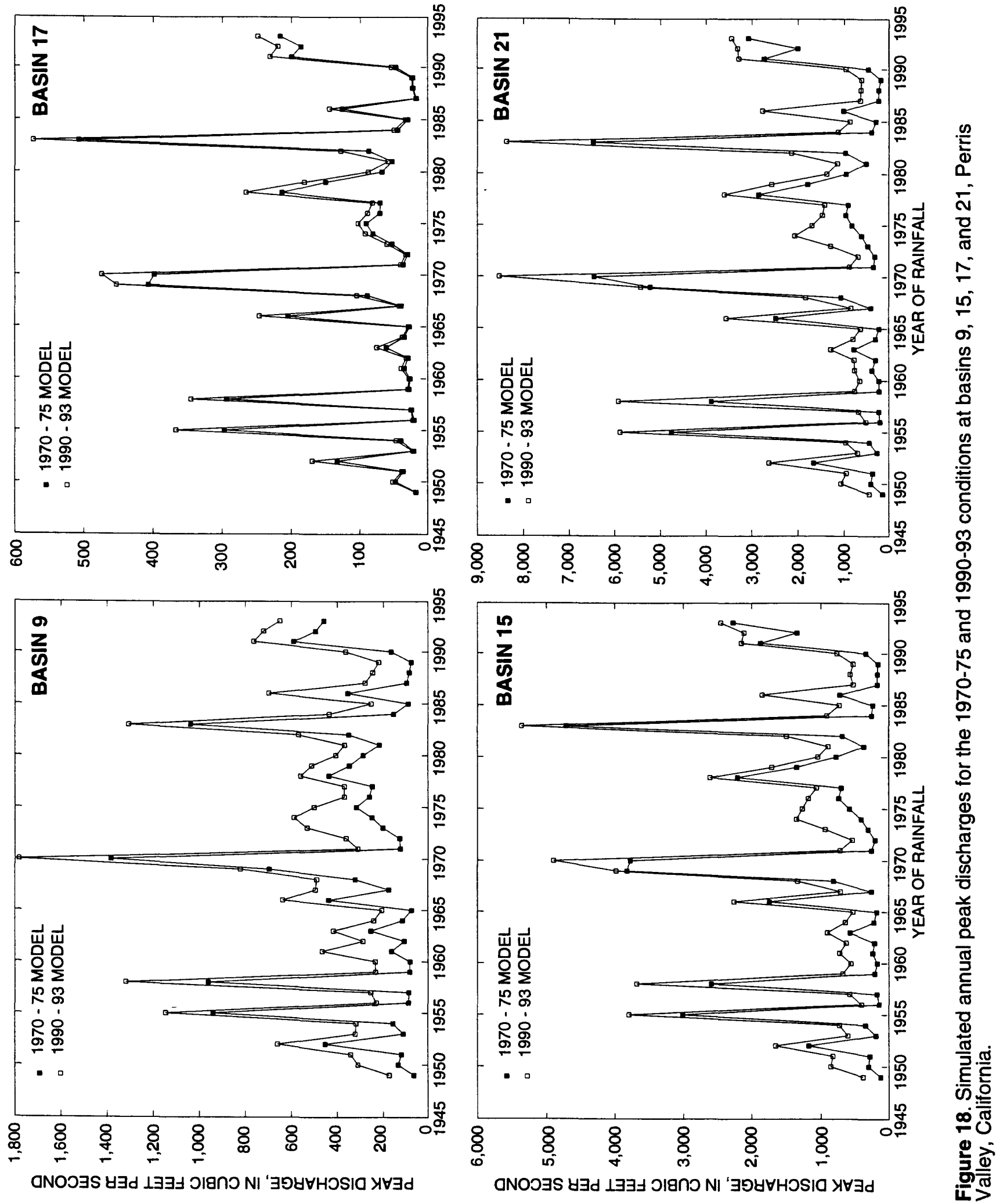

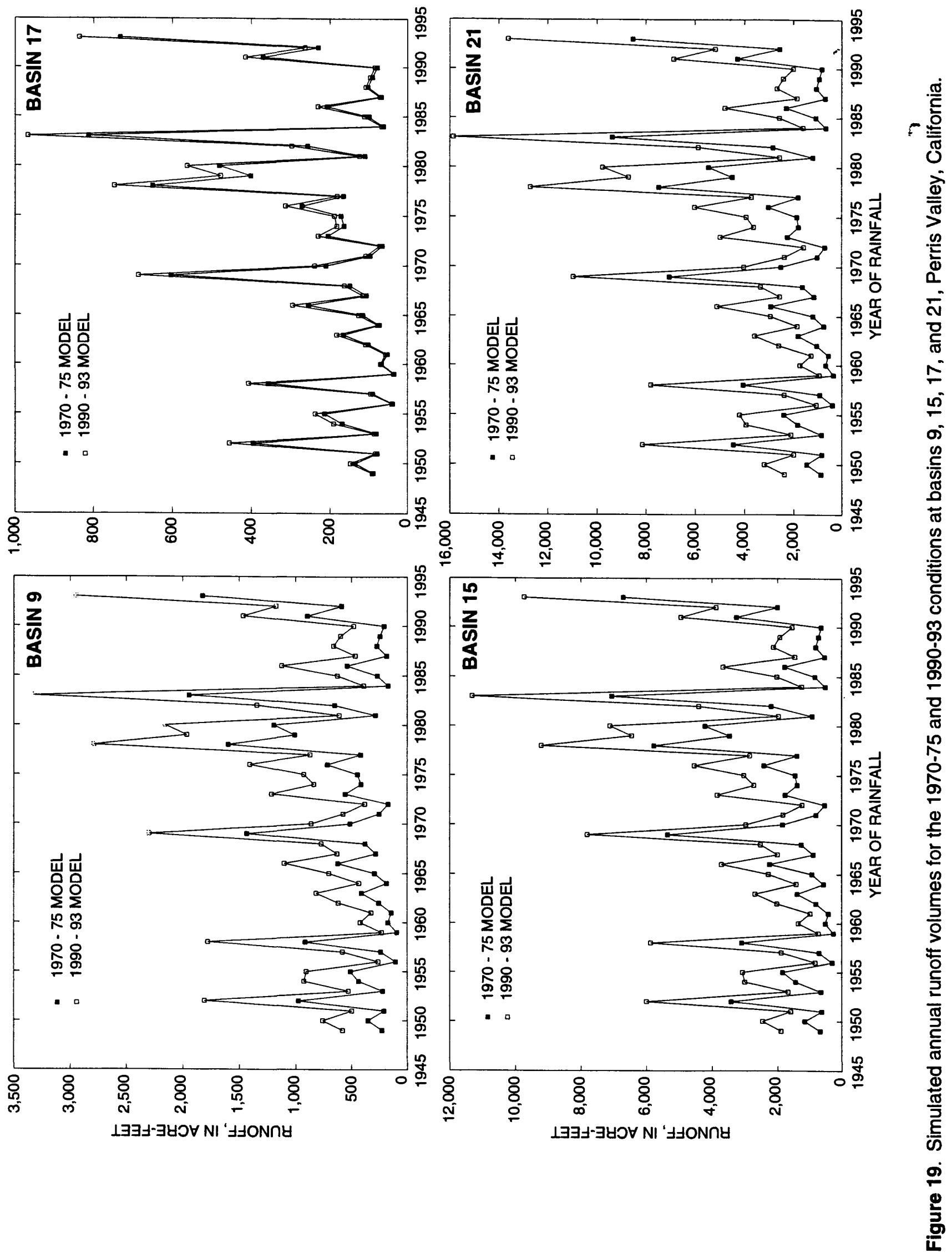

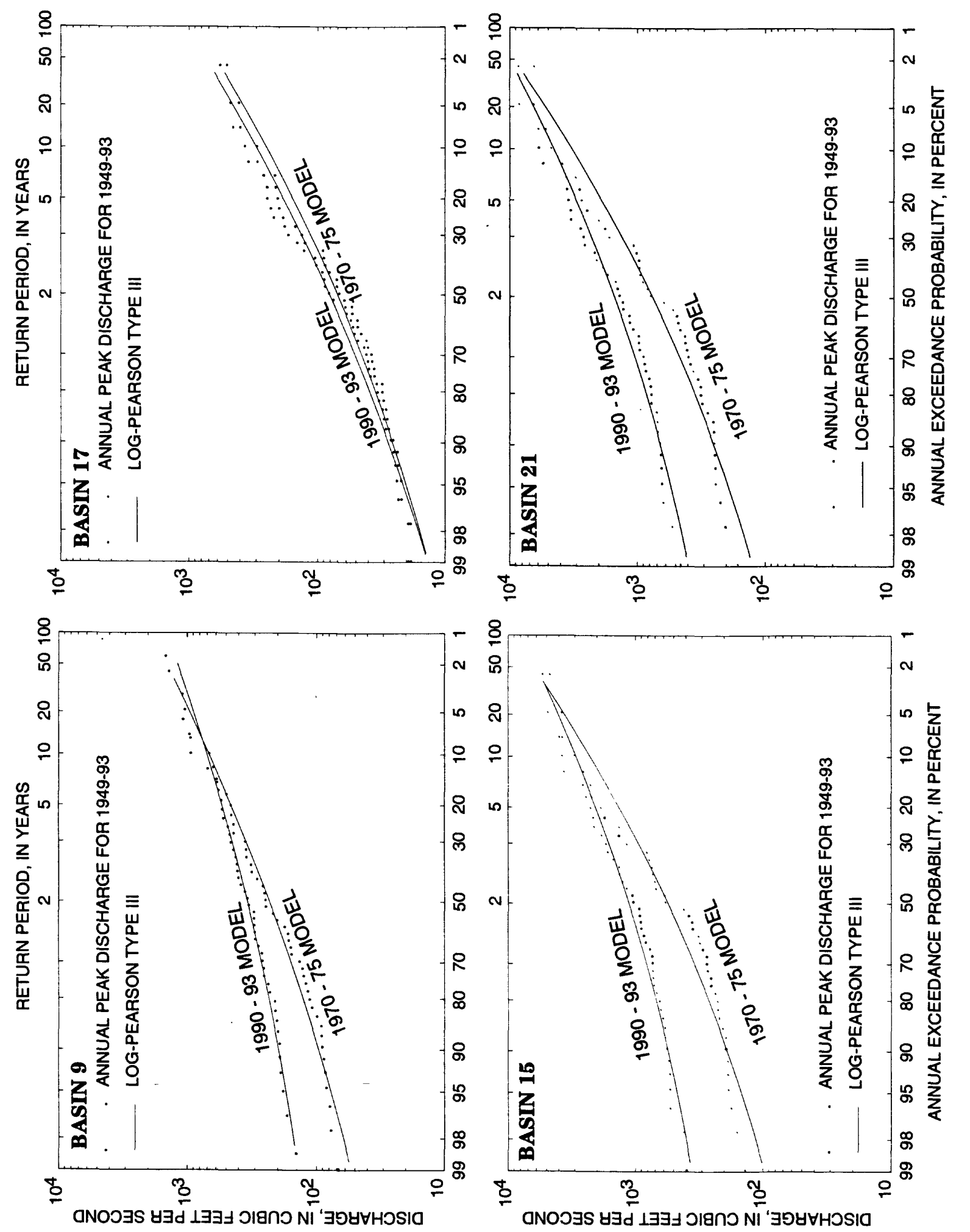

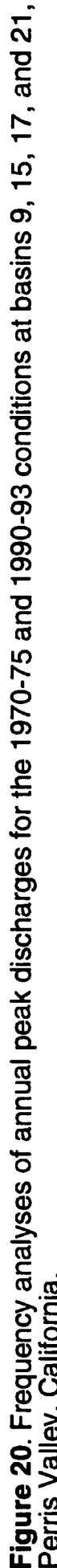



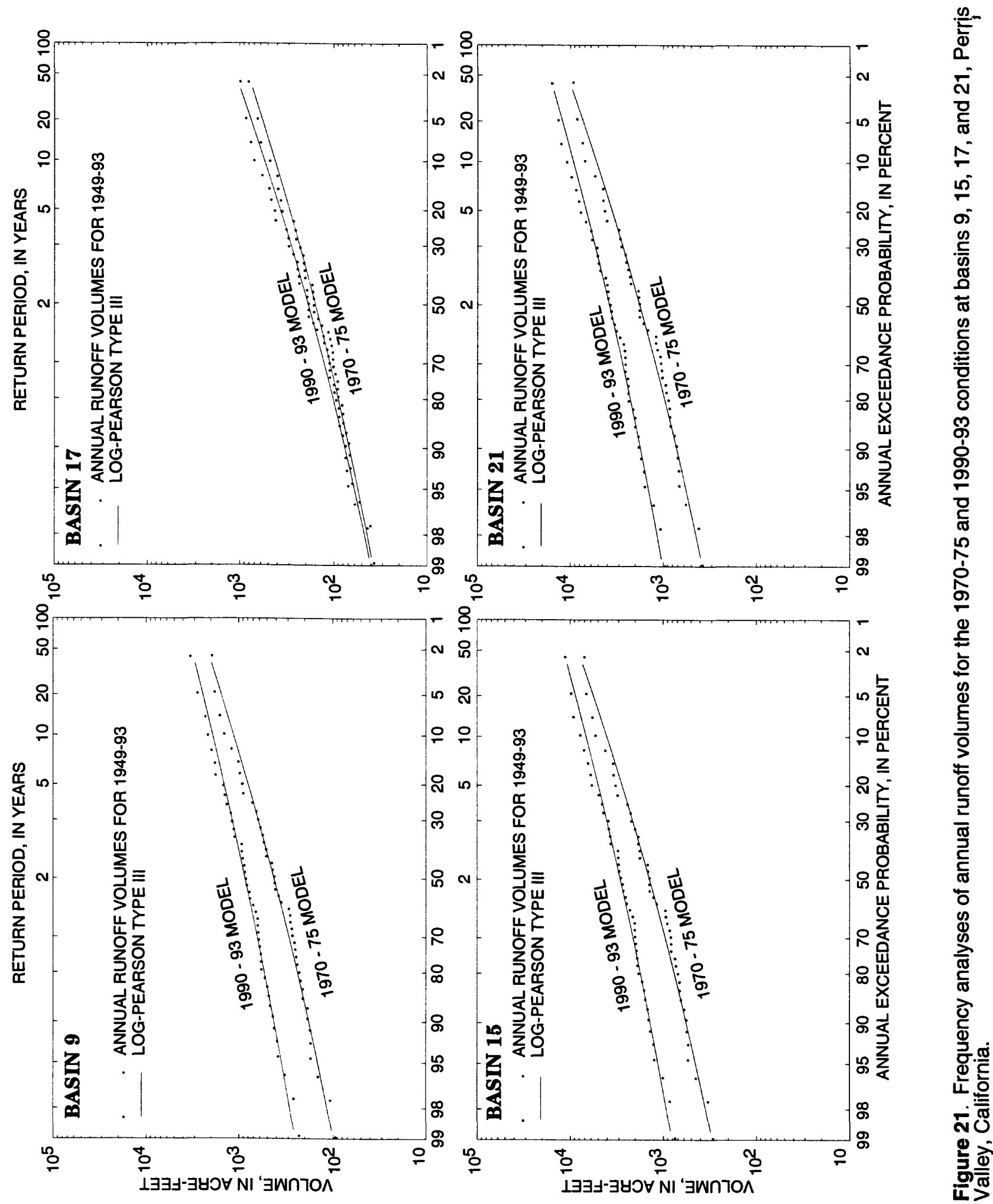

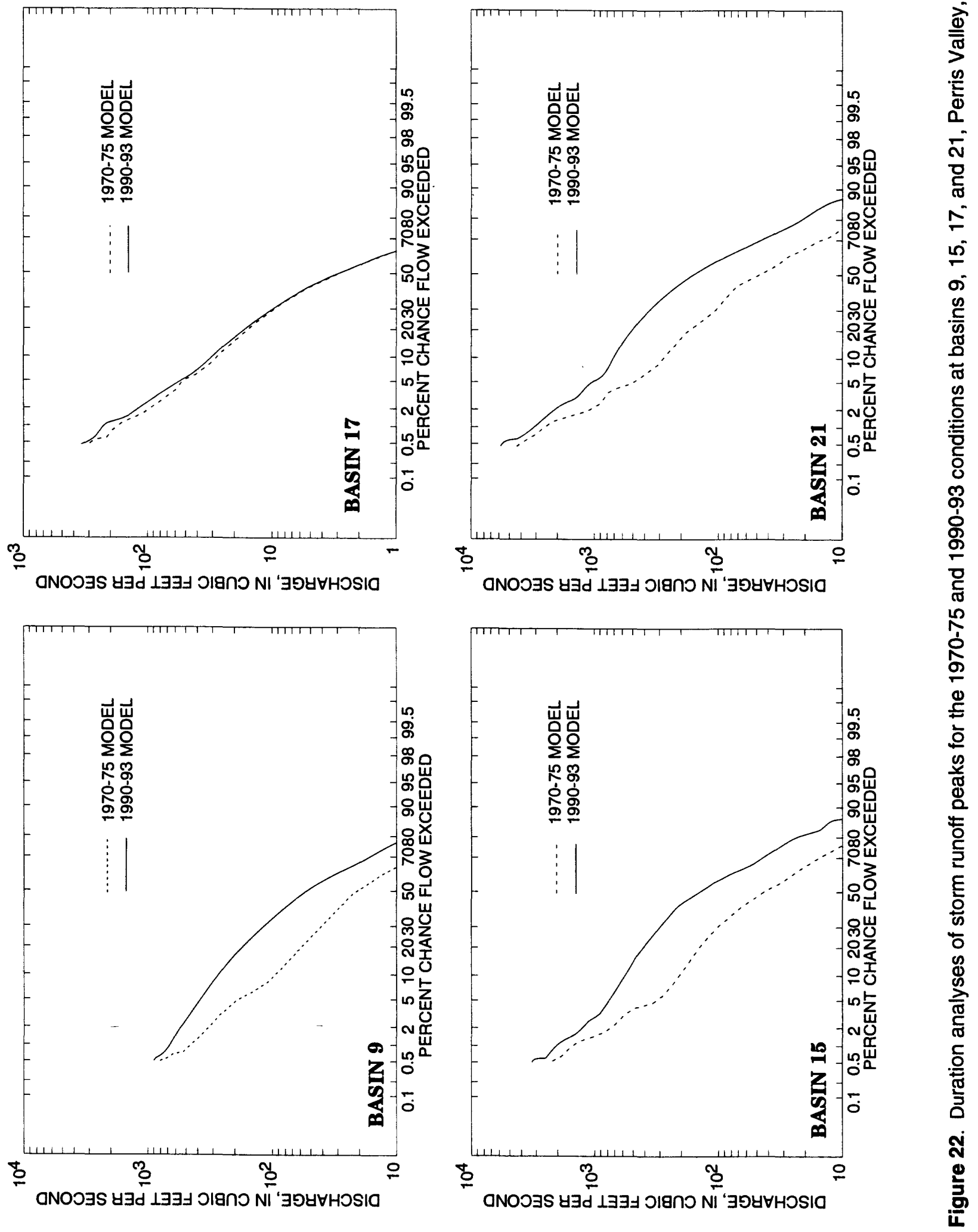

Figure 22

33 
TABLES 1-30

Tales 1-30

Condo.37f a a 
Table 1. Hydrologic and land-use characteristics of the basins, Perris Valley, California, 1972-75

[Hydrologic soil group designations: A, high infiltration rate; B, moderate infiltration rate; C, slow infiltration rate; $D$, very slow infiltration rate (U.S. Soil Conservation Service, 1975)]

\begin{tabular}{lcccc}
\hline & Basin 9 & Basin 15 & Basin 17 & Basin 21 \\
\hline Contributing drainage area (square miles) & 13.52 & 54.22 & 6.99 & 86.33 \\
Urban area (percentage of drainage area) & 15 & 10 & 20 & 10 \\
Impervious area (percentage of drainage area) & 10.7 & 8.3 & 9.0 & 7.8 \\
Hydrologic soil group, Soil Conservation Service methodology & $\mathrm{A}-\mathrm{C}$ & $\mathrm{A}-\mathrm{C}$ & $\mathrm{B}-\mathrm{C}$ & $\mathrm{A}-\mathrm{D}$ \\
Land use (percentage of drainage area): & & & & \\
$\quad$ Residential & 12.7 & 6.5 & 1.0 & 4.8 \\
Commercial and services & .7 & 2.7 & 9.4 & 2.5 \\
Transportation, communication utilities & 0 & .4 & 4.1 & 1.0 \\
Mixed urban and built-up land & .8 & .2 & .4 & .4 \\
Other urban and built-up land & 1.1 & .4 & 4.6 & 1.54 \\
Agriculture & 46.1 & 57.2 & 27.0 & 59.9 \\
Military vacant & 0 & 3.6 & 26.5 & 4.4 \\
Range/open & 37.5 & 28.3 & 25.3 & 24.6 \\
Strip mines, quarries, gravel pits, and transitional areas & .7 & .5 & 1.6 & .8 \\
Detention storage & .4 & .2 & .1 & .1 \\
\hline
\end{tabular}

Table 2. Hydrologic and land-use characteristics of the basins, Perris Valley, California, 1990

[Hydrologic soil group designations: A, high infiltration rate; $B$, moderate infiltration rate; $\mathrm{C}$, slow infiltration rate; $\mathrm{D}$, very slow infiltration rate (U.S. Soil Conservation Service, 1975)]

\begin{tabular}{lcccc}
\hline & Basin 9 & Basin 15 & Basin 17 & Basin 21 \\
\hline Contributing drainage area (square miles) & 13.52 & 54.22 & 6.99 & 86.33 \\
Urban area (percentage of drainage area) & 48 & 41 & 41 & 36 \\
Impervious area (percentage of drainage area) & 26.8 & 23.7 & 17.4 & 22.2 \\
Hydrologic soil group, Soil Conservation Service methodology & $\mathrm{A}-\mathrm{C}$ & $\mathrm{A}-\mathrm{C}$ & $\mathrm{B}-\mathrm{C}$ & $\mathrm{A}-\mathrm{D}$ \\
Land use (percentage of drainage area): & & & & \\
Single-family residential, high density & 26.7 & 19.6 & 0 & 12.9 \\
Single-family residential, low density & 7.5 & 4.8 & 0 & 3.7 \\
Multiple-family residential & 1.4 & .8 & 0 & .5 \\
Trailer parks & 0 & .4 & .4 & .8 \\
Parks, golf courses, and cemeteries & .7 & 1.2 & 16.7 & 2.9 \\
Construction & 3.0 & 3.9 & .1 & 3.0 \\
Rural, high density & 0 & 0 & 0 & .1 \\
Rural, low density & 2.0 & 1.4 & 3.4 & 2.4 \\
Mixed urban & .1 & .1 & 0 & .1 \\
Transportation and services & 1.0 & 1.6 & 2.4 & 2.4 \\
Commercial & 5.1 & 7.2 & 15.9 & 5.9 \\
Open storage & .1 & .1 & 0 & .3 \\
Industrial & .1 & .1 & 1.6 & .6 \\
Agriculture & 2.3 & 14.5 & 18.2 & 22.5 \\
Urban vacant & 3.0 & 3.9 & .1 & 2.6 \\
Military vacant & 0 & 3.6 & 26.5 & 4.4 \\
Range/open & 46.6 & 36.6 & 14.6 & 34.8 \\
Detention storage & .4 & .2 & .1 & .1 \\
\hline
\end{tabular}


Table 3. Components for soil-moisture accounting and infiltration in the rainfall-runoff model

[Modified from Alley and Smith, 1982]

\begin{tabular}{|c|c|}
\hline $\begin{array}{l}\text { Model com- } \\
\text { ponent }\end{array}$ & Soil-moisture accounting \\
\hline EVC & $\begin{array}{l}\text { A coefficient for converting measured pan } \\
\text { evaporation to potential evapotranspiration }\end{array}$ \\
\hline $\mathbf{R R}$ & $\begin{array}{l}\text { The proportion of daily rainfall that infiltrates } \\
\text { into the soil for the period of simulation } \\
\text { excluding unit days }\end{array}$ \\
\hline BMSN & Available soil water at field capacity, in inches \\
\hline $\begin{array}{l}\text { Model com- } \\
\text { ponent }\end{array}$ & Infiltration \\
\hline KSAT & $\begin{array}{l}\text { The effective saturated value of hydraulic } \\
\text { conductivity, in inches per hour }\end{array}$ \\
\hline RGF & $\begin{array}{l}\text { Ratio of suction at the wetting front for soil } \\
\text { moisture at wilting point to that at field } \\
\text { capacity }\end{array}$ \\
\hline PSP & $\begin{array}{l}\text { Suction at wetting front for soil moisture at } \\
\text { field capacity, in inches }\end{array}$ \\
\hline
\end{tabular}

Table 4. Segments of the four basins used in the 1970-75 rainfall-runoff model for Perris Valley, California

[OF01, overland-flow plane segments; $\mathrm{CH} 01$, channel segment; and PI01, pipe segment. ft, foot]

\begin{tabular}{crrrr}
\hline $\begin{array}{c}\text { Model } \\
\text { segment }\end{array}$ & \multicolumn{1}{c}{$\begin{array}{c}\text { Length } \\
\text { (ft) }\end{array}$} & $\begin{array}{r}\text { Slope } \\
\text { (ft/ft) }\end{array}$ & $\begin{array}{c}\text { Roughness } \\
\text { (Manning's }\end{array}$ & $\begin{array}{c}\text { Pipe } \\
\text { diameter } \\
\text { (ft) }\end{array}$ \\
\hline OF01 & \multicolumn{1}{c}{16,884} & 0.300 & 0.030 & \\
OF02 & 10,181 & .350 & .025 & \\
OF03 & 186 & .019 & .020 & \\
OF04 & 7,293 & .040 & .025 & \\
OF05 & 915 & .040 & .020 & \\
& & & & \\
OF06 & 8,183 & .060 & .025 & \\
OF07 & 716 & .060 & .020 & \\
PI01 & 100 & .133 & .015 & 2.5 \\
PI02 & 100 & .007 & .015 & 6.0 \\
CH01 & 9,874 & .300 & .025 & \\
& & & & \\
CH02 & 7,234 & .019 & .020 & \\
CH03 & 4,382 & .010 & .020 & \\
CH04 & 11,246 & .027 & .020 & \\
OF08 & 645 & .013 & .020 & \\
OF09 & 25,152 & .037 & .025 & \\
& & & & \\
CH05 & 43,982 & .013 & .020 & \\
OF10 & 3,735 & .038 & .025 & \\
OF11 & 14,256 & .007 & .025 & \\
OF12 & 7,469 & .007 & .020 & \\
CH06 & 10,560 & .010 & .020 & \\
& & & & \\
CH07 & 5,280 & .010 & .020 & \\
OF13 & 205 & .016 & .020 & \\
OF14 & 20,457 & .060 & .025 & \\
CH08 & 30,000 & .002 & .025 & \\
\hline & & & & \\
\hline
\end{tabular}


Table 5. Segments of the four basins used in the 1990-93 rainfall-runoff model for Perris Valley,

California

[OF01, overland-flow plane segments; CH01, channel segment; and PI01, pipe segment. ft, foot]

\begin{tabular}{|c|c|c|c|c|}
\hline $\begin{array}{c}\text { Model } \\
\text { segment }\end{array}$ & $\begin{array}{l}\text { Length } \\
\text { (ft) }\end{array}$ & $\begin{array}{l}\text { Slope } \\
(\mathrm{ft} / \mathrm{ft})\end{array}$ & $\begin{array}{c}\text { Roughness } \\
\text { (Manning's } \\
n \text { ) }\end{array}$ & $\begin{array}{c}\text { Pipe } \\
\text { diameter } \\
\text { (ft) }\end{array}$ \\
\hline OF01 & 16,884 & 0.300 & 0.030 & \\
\hline OF02 & 9,541 & .350 & .025 & \\
\hline OF03 & 825 & .019 & .020 & \\
\hline OF04 & 4,207 & .040 & .025 & \\
\hline OF05 & 3,999 & .040 & .020 & \\
\hline OF06 & 7,624 & .060 & .025 & \\
\hline OF07 & 1,275 & .060 & .020 & \\
\hline PI01 & 100 & .133 & .015 & 2.5 \\
\hline PI02 & 100 & .007 & .015 & 6.0 \\
\hline $\mathrm{CHO}$ & 9,874 & .300 & .025 & \\
\hline $\mathrm{CHO} 2$ & 7,234 & .019 & .020 & \\
\hline $\mathrm{CHO3}$ & 4,382 & .010 & .020 & \\
\hline $\mathrm{CH} 04$ & 11,246 & .027 & .020 & \\
\hline OF08 & 2,030 & .013 & .020 & \\
\hline OF09 & 23,767 & .037 & .025 & \\
\hline $\mathrm{CH} 05$ & 43,982 & .013 & .020 & \\
\hline OF10 & 3,735 & .038 & .025 & \\
\hline OF11 & 14,256 & .007 & .025 & \\
\hline OF12 & 7,469 & .007 & .020 & \\
\hline CH06 & 10,560 & .010 & .020 & \\
\hline CH07 & 5,280 & .010 & .020 & \\
\hline OF13 & 911 & .016 & .020 & \\
\hline OF14 & 19,950 & .060 & .025 & \\
\hline CH08 & 30,000 & .002 & .025 & \\
\hline
\end{tabular}


Table 6. Summary of measured rainfall and runoff data used to calibrate the1970-75 rainfall-runoff model at basin 9, Perris Valley, California

$\left[\mathrm{ft}^{3}\right.$, cubic foot; $\mathrm{ft}^{3} / \mathrm{s}$, cubic foot per second; $\mathrm{ft}^{2}$, square foot. Total runoff:

$\frac{\text { Total runoff volume }\left(\mathrm{ft}^{3}\right)}{\text { Total area of catchment (acre) }} \cdot \frac{12 \text { (inch) }}{43,560\left(\mathrm{ft}^{2}\right)^{]}}$

\begin{tabular}{|c|c|c|c|c|c|}
\hline Storm date & Time & $\begin{array}{l}\text { Total rainfall } \\
\text { (inches) }\end{array}$ & $\begin{array}{l}\text { Total runoff } \\
\text { (inches) }\end{array}$ & $\begin{array}{c}\text { Peak discharge } \\
\left(\mathrm{ft}^{3} / \mathrm{s}\right)\end{array}$ & $\begin{array}{l}\text { Runoff/rainfall } \\
\text { ratio (percent) }\end{array}$ \\
\hline \multicolumn{6}{|l|}{$\overline{1970}$} \\
\hline February 10-11 & $0045-2400$ & 1.35 & 0.023 & 63.5 & 1 \\
\hline February 28-March 3 & $0900-2400$ & 1.93 & .104 & 153.0 & 5 \\
\hline March 4-5 & $1945-2400$ & .63 & .060 & 145.0 & 10 \\
\hline November $28-30$ & $1715-2400$ & 1.36 & .025 & 91.0 & 2 \\
\hline \multicolumn{6}{|l|}{1972} \\
\hline November $14-15$ & $1030-2400$ & 0.43 & 0.011 & 110.0 & 3 \\
\hline November $16-17$ & $0515-2400$ & .74 & .028 & 120.0 & 4 \\
\hline December 4-5 & $0715-2400$ & .66 & .036 & 67.0 & 5 \\
\hline December 7-8 & $0100-2400$ & .40 & .038 & 87.4 & 10 \\
\hline \multicolumn{6}{|l|}{1973} \\
\hline February 11-14 & $0515-2400$ & 1.78 & 0.175 & 135.0 & 9 \\
\hline February 15 & $0615-2400$ & .19 & .019 & 83.9 & 10 \\
\hline March 6-9 & $0715-2400$ & .72 & .077 & 135.0 & 11 \\
\hline March 20-22 & $0600-2400$ & .71 & .045 & 82.3 & 6 \\
\hline \multicolumn{6}{|l|}{1974} \\
\hline January $4-8$ & $1100-2400$ & 4.15 & 0.276 & 152.0 & 6 \\
\hline March 7-9 & $1330-2400$ & 1.17 & .058 & 74.4 & 2 \\
\hline
\end{tabular}


Table 7. Measured and simulated runoff volumes and peak discharges for all storms used in calibration of the 1970-75 rainfall-runoff model at basin 9, Perris Valley, California

$\left[\mathrm{ft}^{3}\right.$, cubic foot; $\mathrm{ft}^{3} / \mathrm{s}$, cubic foot per second; $\mathrm{ft}^{2}$, square foot.

Runoff volume: $\frac{\text { Total runoff volume }\left(\mathrm{ft}^{3}\right)}{\text { Total area of catchment (acre) }} \cdot \frac{12 \text { (inch) }}{43,560\left(\mathrm{ft}^{2}\right)}$.

Error: (simulated value-measured value)/measured value • 100]

\begin{tabular}{|c|c|c|c|c|c|c|}
\hline \multirow[b]{2}{*}{ Storm date } & \multicolumn{3}{|c|}{ Runoff volume (inches) } & \multicolumn{3}{|c|}{ Peak discharge $\left(\mathrm{ft}^{3} / \mathrm{s}\right)$} \\
\hline & Measured & Simulated & $\begin{array}{c}\text { Error } \\
\text { (percent) }\end{array}$ & Measured & Simulated & $\begin{array}{c}\text { Error } \\
\text { (percent) }\end{array}$ \\
\hline \multicolumn{7}{|l|}{$\overline{1970}$} \\
\hline February $10-11$ & 0.023 & 0.087 & 280 & 63.5 & 116.0 & 83 \\
\hline February 28-March 3 & .104 & .099 & -5 & 153.0 & 89.7 & -41 \\
\hline March 4-5 & .060 & .043 & -28 & 145.0 & 66.7 & -54 \\
\hline November $28-30$ & .025 & .076 & 204 & 91.0 & 71.7 & -21 \\
\hline \multicolumn{7}{|l|}{1972} \\
\hline November $14-15$ & 0.011 & 0.023 & 109 & 110.0 & 98.8 & -10 \\
\hline November $16-17$ & .028 & .035 & 25 & 120.0 & 56.7 & -53 \\
\hline December 4-5 & .036 & .036 & 0 & 67.0 & 85.3 & 27 \\
\hline December 7-8 & .038 & .014 & -63 & 87.4 & 45.2 & -48 \\
\hline \multicolumn{7}{|l|}{1973} \\
\hline February 11-14 & 0.175 & 0.122 & -30 & 135.0 & 105.0 & -22 \\
\hline February 15 & .019 & .009 & -53 & 83.9 & 52.8 & -37 \\
\hline March 6-9 & .077 & .032 & -58 & 135.0 & 59.2 & -56 \\
\hline March 20-22 & .045 & .033 & -27 & 82.3 & 56.8 & -31 \\
\hline \multicolumn{7}{|l|}{1974} \\
\hline January 4-8 & 0.276 & 0.367 & 33 & 152.0 & 143.0 & -6 \\
\hline March 7-9 & .058 & .020 & -66 & 74.4 & 69.5 & -7 \\
\hline
\end{tabular}

Table 8. Final values for soil-moisture and infiltration components, Perris Valley, California

[Definitions and units of measurement of model components are given in table 3]

\begin{tabular}{|c|c|c|c|c|c|c|c|c|}
\hline \multirow{2}{*}{$\begin{array}{c}\text { Model } \\
\text { component }\end{array}$} & \multicolumn{2}{|c|}{ Subbasin A } & \multicolumn{2}{|c|}{ Subbasin B } & \multicolumn{2}{|c|}{ Subbasin C } & \multicolumn{2}{|c|}{ Subbasin D } \\
\hline & $1970-75$ & $1990-93$ & $1970-75$ & $1990-93$ & $1970-75$ & $1990-93$ & $1970-75$ & $1990-93$ \\
\hline EVC & 0.70 & 0.70 & 0.70 & 0.70 & 0.70 & 0.70 & 0.70 & 0.70 \\
\hline$R R$ & .97 & .90 & .98 & .92 & .97 & .97 & .98 & .93 \\
\hline BMSN & 3.90 & 3.90 & 3.90 & 3.90 & 3.90 & 3.90 & 3.90 & 3.90 \\
\hline KSAT & .17 & .17 & .21 & .21 & .21 & .21 & .21 & .21 \\
\hline RGF & 10.00 & 10.00 & 10.00 & 10.00 & 10.00 & 10.00 & 10.00 & 10.00 \\
\hline PSP & .52 & .52 & .52 & .52 & .52 & .52 & .52 & .52 \\
\hline
\end{tabular}


Table 9. Summary of rainfall and runoff data used to calibrate and verify the 1990-93 rainfall-runoff model at basin 9, Perris Valley, California

$\left[\mathrm{ft}^{3}\right.$, cubic foot; $\mathrm{ft}^{3} / \mathrm{s}$, cubic foot per second; $\mathrm{ft}^{2}$, square foot

Total runoff: $\frac{\text { Total runoff volume }\left(\mathrm{ft}^{3}\right)}{\text { Total area of catchment (acre) }} \cdot \frac{12 \text { (inch) }}{43,560\left(\mathrm{ft}^{2}\right)^{]}}$

\begin{tabular}{|c|c|c|c|c|c|}
\hline Storm date & Time & $\begin{array}{l}\text { Total rainfall } \\
\text { (inches) }\end{array}$ & $\begin{array}{l}\text { Total runoff } \\
\text { (inches) }\end{array}$ & $\begin{array}{l}\text { Peak discharge } \\
\left(\mathrm{ft}^{3} / \mathrm{s}\right)\end{array}$ & $\begin{array}{l}\text { Runoff/rainfall } \\
\text { ratio (percent) }\end{array}$ \\
\hline \multicolumn{6}{|l|}{$\overline{1990}$} \\
\hline January $1-2$ & $2300-1800$ & 0.31 & 0.025 & 148.0 & 8 \\
\hline February 4-5 & 0900-0400 & .40 & .032 & 127.0 & 8 \\
\hline February $17-19$ & $0245-1200$ & 1.19 & .322 & 561.0 & 27 \\
\hline March 5 & $0100-0600$ & .14 & .007 & 55.0 & 5 \\
\hline April 4 & $1115-1800$ & .19 & .018 & 80.8 & 9 \\
\hline May 28 & $0315-2000$ & .47 & .027 & 157.0 & 5 \\
\hline \multicolumn{6}{|l|}{1991} \\
\hline January 3-5 & $0500-1200$ & 1.80 & 0.174 & 183.0 & 9 \\
\hline January 9 & $1000-2400$ & .40 & .030 & 75.3 & 7 \\
\hline February 27-March 2 & $1115-1200$ & 4.07 & 1.106 & 334.0 & 27 \\
\hline March 13 & $1430-1600$ & .38 & .066 & 107.0 & 17 \\
\hline March 18-21 & $2315-1800$ & 1.69 & .219 & 182.0 & 13 \\
\hline March 25-27 & $0330-2400$ & 2.23 & .315 & 436.0 & 14 \\
\hline October $26-27$ & 0900-0400 & .21 & .027 & 224.0 & 12 \\
\hline December 27-30 & $2330-1200$ & .95 & .109 & 155.0 & 11 \\
\hline \multicolumn{6}{|l|}{1992} \\
\hline January 5-8 & $0430-1200$ & 1.89 & 0.295 & 238.0 & 15 \\
\hline February 5-7 & $1915-2400$ & .73 & .057 & 96.6 & 7 \\
\hline February 9 & $0345-2400$ & .31 & .022 & 58.2 & 7 \\
\hline February 11-12 & $0815-2400$ & 2.46 & .500 & 1300.0 & 20 \\
\hline February $15-16$ & $0300-0400$ & .83 & .127 & 311.0 & 15 \\
\hline March 2-3 & $0345-2400$ & .85 & .051 & 84.1 & 6 \\
\hline March 6-8 & $0600-1200$ & .30 & .051 & 353.0 & 17 \\
\hline December 4 & $0600-1600$ & .38 & .019 & 118.0 & 5 \\
\hline December 6-8 & $1800-0800$ & 2.29 & .470 & 643.0 & 20 \\
\hline December 27-30 & $1700-1200$ & 1.15 & .128 & 425.0 & 11 \\
\hline \multicolumn{6}{|l|}{1993} \\
\hline January 5-8 & $2200-2400$ & 2.62 & 0.991 & 713.0 & 37 \\
\hline January $15-19$ & $0530-1200$ & 4.64 & 1.628 & 1030.0 & 35 \\
\hline January $30-$ February 1 & $2330-2400$ & .15 & .006 & 42.0 & 4 \\
\hline February $7-9$ & $1215-0600$ & 1.71 & .541 & 856.0 & 31 \\
\hline February $14-15$ & $1715-0100$ & .13 & .005 & 21.8 & 3 \\
\hline February $18-20$ & $2030-2400$ & .91 & .229 & 233.0 & 25 \\
\hline
\end{tabular}


Table 10. Measured and simulated runoff volumes and peak discharges for all storms used in calibration and verification of the 1990-93 rainfall-runoff model at basin 9, Perris Valley, California

$\left[\mathrm{ft}^{3}\right.$, cubic foot; $\mathrm{ft}^{3} / \mathrm{s}$, cubic foot per second; $\mathrm{ft}^{2}$, square foot.

Runoff volume: $\frac{\text { Total runoff volume }\left(\mathrm{ft}^{3}\right)}{\text { Total area of catchment (acre) }} \cdot \frac{12 \text { (inch) }}{43,560\left(\mathrm{ft}^{2}\right)}$.

Error: (simulated value-measured value)/measured value • 100]

\begin{tabular}{|c|c|c|c|c|c|c|}
\hline \multirow[b]{2}{*}{ Storm date } & \multicolumn{3}{|c|}{ Runoff volume (inches) } & \multicolumn{3}{|c|}{ Peak discharge $\left(\mathrm{ft}^{3} / \mathrm{s}\right)$} \\
\hline & Measured & Simulated & $\begin{array}{c}\text { Error } \\
\text { (percent) }\end{array}$ & Measured & Simulated & $\begin{array}{c}\text { Error } \\
\text { (percent) }\end{array}$ \\
\hline \multicolumn{7}{|c|}{ Calibration } \\
\hline 1990 & & & & & & \\
\hline March 5 & 0.007 & 0.012 & 71 & 55.0 & 76.1 & 38 \\
\hline April 4 & .018 & .017 & -6 & 80.8 & 83.1 & 3 \\
\hline \multicolumn{7}{|l|}{1991} \\
\hline January $3-5$ & 0.174 & 0.239 & 37 & 183.0 & 240.0 & 31 \\
\hline January 9 & .030 & .046 & 53 & 75.4 & 112.0 & 49 \\
\hline February 27-March 2 & 1.120 & 1.040 & -7 & 334.0 & 572.0 & 71 \\
\hline March 25-27 & .315 & 686 & 118 & 436.0 & 774.0 & 78 \\
\hline December 27-30 & .109 & .108 & -1 & 155.0 & 177.0 & 14 \\
\hline \multicolumn{7}{|l|}{1992} \\
\hline January 5-8 & 0.295 & 0.244 & -17 & 238.0 & 161.0 & -32 \\
\hline February $5-7$ & .057 & .074 & 30 & 96.6 & 159.0 & 65 \\
\hline February $11-12$ & .500 & .593 & 19 & $1,300.0$ & 898.0 & -31 \\
\hline December 4 & .019 & .039 & 105 & 118.0 & 189.0 & 60 \\
\hline December 6-8 & .470 & .549 & 17 & 643.0 & 506.0 & -21 \\
\hline \multicolumn{7}{|l|}{1993} \\
\hline January $15-19$ & 1.630 & 1.380 & -15 & $1,030.0$ & 952.0 & -8 \\
\hline February $14-15$ & .005 & .011 & 120 & 21.8 & 40.0 & 83 \\
\hline February $18-20$ & .229 & .119 & -48 & 233.0 & 214.0 & -8 \\
\hline \multirow{2}{*}{\multicolumn{7}{|c|}{ Verification }} \\
\hline 1990 & & & & & & \\
\hline January 1-2 & 0.025 & 0.029 & 16 & 148.0 & 77.9 & -47 \\
\hline February 4-5 & .032 & .044 & 38 & 127.0 & 123.0 & -3 \\
\hline February $17-19$ & .322 & .149 & -55 & 561.0 & 269.0 & -52 \\
\hline May 28 & .027 & .047 & 74 & 157.0 & 94.4 & -40 \\
\hline \multicolumn{7}{|l|}{1991} \\
\hline March 13-14 & 0.066 & 0.052 & -21 & 107.0 & 130.0 & 21 \\
\hline March 18-21 & .219 & .282 & 29 & 182.0 & 278.0 & 53 \\
\hline October $26-27$ & .027 & .020 & -26 & 224.0 & 127.0 & -43 \\
\hline \multicolumn{7}{|l|}{1992} \\
\hline February 9 & 0.022 & 0.033 & 50 & 58.2 & 119.0 & 105 \\
\hline February $15-16$ & .127 & .197 & 55 & 311.0 & 440.0 & 41 \\
\hline March 2-3 & .051 & .115 & 125 & 84.2 & 167.0 & 99 \\
\hline March 6-8 & .051 & .037 & -27 & 353.0 & 164.0 & -54 \\
\hline December $27-30$ & .128 & .152 & 19 & 425.0 & 374.0 & -12 \\
\hline \multicolumn{7}{|l|}{1993} \\
\hline January 5-8 & 0.991 & 0.407 & -59 & 713.0 & 410.0 & -42 \\
\hline January 30 -February 1 & .006 & .013 & 117 & 42.0 & 65.6 & 56 \\
\hline February $7-9$ & .541 & .574 & -6 & 856.0 & 870.0 & 2 \\
\hline
\end{tabular}


Table 11. Summary of rainfall and runoff data used to calibrate the 1970-75 rainfall-runoff model at basin 15, Perris Valley, California

$\left[\mathrm{ft}^{3}\right.$, cubic foot; $\mathrm{ft}^{3} / \mathrm{s}$, cubic foot per second; $\mathrm{ft}^{2}$, square foot.

Total runoff: $\frac{\text { Total runoff volume }\left(\mathrm{ft}^{3}\right)}{\text { Total area of catchment (acre) }} \cdot \frac{12 \text { (inch) }}{43,560\left(\mathrm{ft}^{2}\right)^{]}}$

\begin{tabular}{|c|c|c|c|c|c|}
\hline Storm date & Time & $\begin{array}{l}\text { Total rainfall } \\
\text { (inches) }\end{array}$ & $\begin{array}{c}\text { Total runoff } \\
\text { (inches) }\end{array}$ & $\begin{array}{l}\text { Peak discharge } \\
\left(\mathrm{ft}^{3} / \mathrm{s}\right)\end{array}$ & $\begin{array}{l}\text { Runoff/rainfall } \\
\text { ratio (percent) }\end{array}$ \\
\hline \multicolumn{6}{|l|}{$\overline{1970}$} \\
\hline February $10-11$ & $0045-2400$ & 1.35 & 0.039 & 173.0 & 3 \\
\hline February 28-March 3 & $0900-2400$ & 2.07 & .090 & 145.0 & 4 \\
\hline March 4-5 & $1945-2400$ & .54 & .043 & 208.0 & 8 \\
\hline November $28-30$ & $1715-2400$ & 1.36 & .047 & 195.0 & 3 \\
\hline December 21-22 & $0015-2400$ & .79 & .075 & 226.0 & 9 \\
\hline \multicolumn{6}{|l|}{1971} \\
\hline January 2 & $0545-2400$ & 0.21 & 0.011 & 82.0 & 5 \\
\hline \multicolumn{6}{|l|}{1972} \\
\hline November $14-15$ & $1030-2400$ & 0.43 & 0.015 & 128.0 & 3 \\
\hline November $16-17$ & $0515-2400$ & .74 & .057 & 228.0 & 7 \\
\hline December 4-5 & $0715-2400$ & .66 & .030 & 198.0 & 4 \\
\hline \multicolumn{6}{|l|}{1973} \\
\hline January $16-17$ & $1330-2400$ & 0.68 & 0.024 & 204.0 & 3 \\
\hline January $18-19$ & $1830-2400$ & .71 & .040 & 242.0 & 5 \\
\hline February 5-8 & $2215-2400$ & .75 & .024 & 145.0 & 3 \\
\hline February $11-14$ & $0215-2400$ & 1.72 & .217 & 488.0 & 12 \\
\hline March 6-9 & $0715-2400$ & .72 & .036 & 118.0 & 5 \\
\hline March 11-12 & $0845-2400$ & .53 & .032 & 108.0 & 6 \\
\hline March 20-22 & $0600-2400$ & .70 & .044 & 197.0 & 6 \\
\hline \multicolumn{6}{|l|}{1974} \\
\hline January 4-8 & $1100-2400$ & 4.40 & 0.277 & 472.0 & 6 \\
\hline March 2-4 & $0345-2400$ & .48 & .014 & 82.0 & 3 \\
\hline March 7-9 & $1330-2400$ & 1.11 & .062 & 183.0 & 5 \\
\hline
\end{tabular}


Table 12. Measured and simulated runoff volumes and peak discharges for all storms used in calibration of the 1970-75 rainfall-runoff model at basin 15, Perris Valley, California

$\left[\mathrm{ft}^{3}\right.$, cubic foot; $\mathrm{ft}^{3} / \mathrm{s}$, cubic foot per second; $\mathrm{ft}^{2}$, square foot.

Runoff volume: $\frac{\text { Total runoff volume }\left(\mathrm{ft}^{3}\right)}{\text { Total area of catchment (acre) }} \cdot \frac{12 \text { (inch) }}{43,560\left(\mathrm{ft}^{2}\right)}$.

Error: (simulated value-measured value)/measured value $\bullet 100$ ]

\begin{tabular}{|c|c|c|c|c|c|c|}
\hline \multirow{2}{*}{ Storm date } & \multicolumn{3}{|c|}{ Runoff volume (inches) } & \multicolumn{3}{|c|}{ Peak discharge $\left(\mathrm{ft}^{3} / \mathrm{s}\right)$} \\
\hline & Measured & Simulated & $\begin{array}{c}\text { Error } \\
\text { (percent) }\end{array}$ & Measured & Simulated & $\underset{\text { (percent) }}{\text { Error }}$ \\
\hline \multicolumn{7}{|l|}{$\overline{1970}$} \\
\hline February 10-11 & 0.039 & 0.067 & 72 & 173.0 & 248.0 & 43 \\
\hline February 28-March 3 & .090 & .083 & -8 & 145.0 & 171.0 & 18 \\
\hline March 4-5 & .043 & .030 & -30 & 208.0 & 158.0 & -24 \\
\hline November $28-30$ & .047 & .057 & 21 & 195.0 & 175.0 & -10 \\
\hline December 21-22 & .075 & .039 & -48 & 226.0 & 280.0 & 24 \\
\hline \multicolumn{7}{|l|}{1971} \\
\hline January 2 & 0.011 & 0.005 & -55 & 82.0 & 76.3 & -7 \\
\hline \multicolumn{7}{|l|}{1972} \\
\hline November $14-15$ & 0.015 & 0.016 & 7 & 128.0 & 201.0 & 57 \\
\hline November $16-17$ & .057 & .025 & -56 & 228.0 & 113.0 & -50 \\
\hline December 4-5 & .030 & .027 & -10 & 198.0 & 193.0 & -3 \\
\hline \multicolumn{7}{|l|}{1973} \\
\hline January 16-17 & 0.024 & 0.027 & 13 & 204.0 & 164.0 & -20 \\
\hline January 18-19 & .040 & .028 & -30 & 242.0 & 189.0 & -22 \\
\hline February 5-8 & .024 & .024 & 0 & 145.0 & 144.0 & -1 \\
\hline February 11-14 & .217 & .110 & -49 & 488.0 & 273.0 & -61 \\
\hline March 6-9 & .036 & .023 & -36 & 118.0 & 134.0 & 14 \\
\hline March 11-12 & .032 & .014 & -56 & 108.0 & 83.9 & -22 \\
\hline March 20-22 & .044 & 0.025 & -43 & 197.0 & 137.0 & -30 \\
\hline \multicolumn{7}{|l|}{1974} \\
\hline January 4-8 & 0.277 & 0.371 & 34 & 472.0 & 487.0 & 3 \\
\hline March 2-4 & .014 & .017 & 21 & 82.0 & 87.6 & 7 \\
\hline March 7-9 & .062 & .038 & -39 & 183.0 & 103.0 & -44 \\
\hline
\end{tabular}


Table 13. Summary of rainfall and runoff data used to calibrate and verify the 1990-93 rainfall-runoff model at basin 15, Perris Valley, California

$\left[\mathrm{ft}^{3}\right.$, cubic foot; $\mathrm{ft}^{3} / \mathrm{s}$, cubic foot per second; $\mathrm{ft}^{2}$, square foot

Total runoff: $\left.\frac{\text { Total runoff volume }\left(\mathrm{ft}^{3}\right)}{\text { Total area of catchment (acre) }} \cdot \frac{12 \text { (inch) }}{43,560\left(\mathrm{ft}^{2}\right)}\right]$

\begin{tabular}{|c|c|c|c|c|c|}
\hline Storm date & Time & $\begin{array}{l}\text { Total rainfall } \\
\text { (inches) }\end{array}$ & $\begin{array}{l}\text { Total runoff } \\
\text { (inches) }\end{array}$ & $\begin{array}{c}\text { Peak discharge } \\
\left(\mathrm{ft}^{3} / \mathrm{s}\right)\end{array}$ & $\begin{array}{l}\text { Runoff/rainfall } \\
\text { ratio (percent) }\end{array}$ \\
\hline \multicolumn{6}{|l|}{1990} \\
\hline January $13-16$ & $0015-0600$ & 0.68 & 0.034 & 172.0 & 5 \\
\hline January $16-18$ & $1245-2400$ & .36 & .028 & 109.0 & 7 \\
\hline February $17-19$ & $0300-2345$ & 1.19 & .137 & 639.0 & 11 \\
\hline \multicolumn{6}{|l|}{1991} \\
\hline January 3-5 & $0515-2400$ & 1.19 & 0.207 & $1,040.0$ & 17 \\
\hline January 9-10 & $1015-2345$ & .47 & .032 & 250.0 & 6 \\
\hline February 27-March 3 & $1130-2400$ & 4.17 & .695 & $1,300.0$ & 16 \\
\hline March 13-14 & $1445-2345$ & .30 & .037 & 261.0 & 12 \\
\hline March 18-21 & $2330-2400$ & 1.78 & .210 & 681.0 & 11 \\
\hline March 25-28 & $0345-1200$ & 2.23 & .453 & $2,090.0$ & 20 \\
\hline December 27-30 & $2345-2400$ & 1.00 & .093 & 402.0 & 9 \\
\hline \multicolumn{6}{|l|}{1992} \\
\hline January 5-8 & $0445-2300$ & 1.71 & 0.369 & $1,160.0$ & 21 \\
\hline February 5-8 & $1930-1200$ & .98 & .071 & 321.0 & 7 \\
\hline February $9-10$ & $2300-2345$ & .35 & .026 & 191.0 & 7 \\
\hline February $11-13$ & $0830-0500$ & 2.04 & .580 & $4,880.0$ & 28 \\
\hline February $15-16$ & $0315-2300$ & .82 & .195 & $1,450.0$ & 23 \\
\hline March 2-4 & $0400-2345$ & .85 & .051 & 207.0 & 6 \\
\hline March 6-8 & $0615-2300$ & .31 & .068 & 916.0 & 21 \\
\hline March 20-24 & $1415-2300$ & 1.69 & .242 & 681.0 & 14 \\
\hline March 26-29 & $1915-2400$ & .46 & .041 & 129.0 & 8 \\
\hline December 6-8 & $1815-1200$ & 2.83 & .627 & $2,880.0$ & 22 \\
\hline December 27-31 & $1715-2400$ & 1.24 & .187 & $1,140.0$ & 15 \\
\hline \multicolumn{6}{|l|}{1993} \\
\hline February $18-21$ & $1015-0600$ & 1.69 & 0.361 & $1,000.0$ & 21 \\
\hline
\end{tabular}


Table 14. Measured and simulated runoff volumes and peak discharges for all storms used in calibration and verification of the 1990-93 rainfall-runoff model at basin 15, Perris Valley, California

$\left[\mathrm{ft}^{3}\right.$, cubic foot; $\mathrm{ft}^{3} / \mathrm{s}$, cubic foot per second; $\mathrm{ft}^{2}$, square foot.

Runoff volume: $\frac{\text { Total runoff volume }\left(\mathrm{ft}^{3}\right)}{\text { Total area of catchment (acre) }} \cdot \frac{12 \text { (inch) }}{43,560\left(\mathrm{ft}^{2}\right)}$.

Error: (simulated value-measured value)/measured value $\bullet 100$ ]

\begin{tabular}{|c|c|c|c|c|c|c|}
\hline \multirow[b]{2}{*}{ Storm date } & \multicolumn{3}{|c|}{ Runoff volume (inches) } & \multicolumn{3}{|c|}{ Peak discharge $\left(\mathrm{ft}^{3} / \mathrm{s}\right)$} \\
\hline & Measured & Simulated & $\begin{array}{c}\text { Error } \\
\text { (percent) }\end{array}$ & Measured & Simulated & $\begin{array}{c}\text { Error } \\
\text { (percent) }\end{array}$ \\
\hline \multicolumn{7}{|c|}{ Calibration } \\
\hline \multicolumn{7}{|l|}{$\overline{1990}$} \\
\hline February 17-19 & 0.137 & 0.123 & -10 & 639.0 & 688.0 & 8 \\
\hline \multicolumn{7}{|l|}{1991} \\
\hline January 9-10 & .0032 & 0.042 & 31 & 250.0 & 472.0 & 89 \\
\hline March 13-14 & .037 & .033 & -11 & 261.0 & 429.0 & 64 \\
\hline March 18-21 & .210 & .245 & 17 & 681.0 & 642.0 & -6 \\
\hline March 25-28 & .453 & .609 & 34 & $2,090.0$ & $3,180.0$ & 52 \\
\hline \multicolumn{7}{|l|}{1992} \\
\hline February 5-8 & 0.071 & 0.079 & 11 & 321.0 & 423.0 & 32 \\
\hline February $9-10$ & .026 & .030 & 15 & 191.0 & 424.0 & 122 \\
\hline February $15-16$ & .195 & .145 & -26 & $1,450.0$ & 981.0 & -32 \\
\hline March 2-4 & .051 & .090 & 76 & 207.0 & 430.0 & 108 \\
\hline December 6-8 & .627 & .728 & 16 & $2,880.0$ & $3,890.0$ & 35 \\
\hline \multicolumn{7}{|l|}{1993} \\
\hline February $18-21$ & 0.361 & 0.286 & -21 & $1,000.0$ & 890.0 & -11 \\
\hline \multicolumn{7}{|c|}{ Verification } \\
\hline \multicolumn{7}{|l|}{1990} \\
\hline January $13-16$ & 0.034 & 0.057 & 68 & 172.0 & 484.0 & 181 \\
\hline January $16-18$ & .028 & .032 & 14 & 109.0 & 348.0 & 219 \\
\hline \multicolumn{7}{|l|}{1991} \\
\hline January 3-5 & 0.207 & 0.145 & -30 & $1,040.0$ & 653.0 & -37 \\
\hline February 27-March 3 & .695 & .879 & 26 & $1,300.0$ & $1,660.0$ & 28 \\
\hline December 27-30 & .093 & .093 & 0 & 402.0 & 506.0 & 26 \\
\hline \multicolumn{7}{|l|}{1992} \\
\hline January 5-8 & 0.369 & 0.185 & -50 & $1,160.0$ & 546.0 & -53 \\
\hline February 11-13 & .580 & .511 & -12 & $4,880.0$ & $4,520.0$ & -7 \\
\hline March 6-8 & .068 & .028 & -59 & 916.0 & 376.0 & -59 \\
\hline March 20-24 & .242 & .207 & -14 & 681.0 & $1,000.0$ & 47 \\
\hline March 26-29 & .041 & .040 & -2 & 129.0 & 271.0 & 110 \\
\hline December 27-31 & .187 & .129 & -31 & $1,140.0$ & 736.0 & -35 \\
\hline
\end{tabular}


Table 15. Summary of rainfall and runoff data used to calibrate the 1970-75 rainfall-runoff model at basin 17 , Perris Valley, California

$\left[\mathrm{ft}^{3}\right.$, cubic foot; $\mathrm{ft}^{3} / \mathrm{s}$, cubic foot per second; $\mathrm{ft}^{2}$, square foot.

Total runoff: $\left.\frac{\text { Total runoff volume }\left(\mathrm{ft}^{3}\right)}{\text { Total area of catchment (acre) }} \cdot \frac{12 \text { (inch) }}{43,560\left(\mathrm{ft}^{2}\right)}\right]$

\begin{tabular}{|c|c|c|c|c|c|}
\hline Storm date & Time & $\begin{array}{l}\text { Total rainfall } \\
\text { (inches) }\end{array}$ & $\begin{array}{l}\text { Total runoff } \\
\text { (inches) }\end{array}$ & $\begin{array}{c}\text { Peak discharge } \\
\left(\mathrm{ft}^{3} / \mathrm{s}\right)\end{array}$ & $\begin{array}{l}\text { Runoff/rainfall } \\
\text { ratio (percent) }\end{array}$ \\
\hline \multicolumn{6}{|l|}{1970} \\
\hline February $10-11$ & $0045-2400$ & 1.35 & 0.055 & 30.1 & 4 \\
\hline December 21-22 & $0015-2400$ & .79 & .042 & 27.6 & 5 \\
\hline \multicolumn{6}{|l|}{1971} \\
\hline December 27-29 & $0815-2400$ & 0.92 & 0.031 & 30.6 & 3 \\
\hline \multicolumn{6}{|l|}{1972} \\
\hline November $16-17$ & $0515-2400$ & 0.74 & 0.030 & 30.0 & 4 \\
\hline \multicolumn{6}{|l|}{1973} \\
\hline January $16-17$ & $1330-2400$ & 0.68 & 0.012 & 21.2 & 2 \\
\hline January $18-19$ & $1830-2400$ & .71 & .046 & 50.3 & 6 \\
\hline February 5-8 & $2215-2400$ & .75 & .021 & 19.7 & 2 \\
\hline February $11-14$ & $0215-2400$ & 1.72 & .158 & 89.0 & 9 \\
\hline \multicolumn{6}{|l|}{1974} \\
\hline January 4-8 & $1100-2400$ & 4.40 & 0.141 & 52.0 & 3 \\
\hline March 7-9 & $1330-2400$ & 1.11 & .071 & 22.8 & 6 \\
\hline \multicolumn{6}{|l|}{1975} \\
\hline March 8-9 & $0400-2400$ & 1.12 & 0.029 & 26.3 & 2 \\
\hline
\end{tabular}


Table 16. Measured and simulated runoff volumes and peak discharges for all storms used in calibration of the 1970-75 rainfall-runoff model at basin 17, Perris Valley, California

$\left[\mathrm{ft}^{3}\right.$, cubic foot; $\mathrm{ft}^{3} / \mathrm{s}$, cubic foot per second; $\mathrm{ft}^{2}$, square foot.

Runoff volume: $\frac{\text { Total runoff volume }\left(\mathrm{ft}^{3}\right)}{\text { Total area of catchment (acre) }} \cdot \frac{12 \text { (inch) }}{43,560\left(\mathrm{ft}^{2}\right)}$.

Error: (simulated value-measured value)/measured value $\bullet 100]$

\begin{tabular}{|c|c|c|c|c|c|c|}
\hline \multirow[b]{2}{*}{ Storm date } & \multicolumn{3}{|c|}{ Runoff volume (inches) } & \multicolumn{3}{|c|}{ Peak discharge $\left(\mathrm{ft}^{3} / \mathrm{s}\right)$} \\
\hline & Measured & Simulated & $\begin{array}{c}\text { Error } \\
\text { (percent) }\end{array}$ & Measured & Simulated & $\begin{array}{c}\text { Error } \\
\text { (percent) }\end{array}$ \\
\hline \multicolumn{7}{|l|}{$\overline{1970}$} \\
\hline February 10-11 & 0.055 & 0.064 & 16 & 30.8 & 27.4 & -11 \\
\hline December 21-22 & .042 & .038 & -10 & 27.6 & 28.8 & 4 \\
\hline \multicolumn{7}{|l|}{1971} \\
\hline December 27-29 & 0.031 & 0.50 & 61 & 30.7 & 34.7 & 13 \\
\hline \multicolumn{7}{|l|}{1972} \\
\hline November $16-17$ & 0.030 & .025 & -17 & 30.1 & 13.3 & -56 \\
\hline \multicolumn{7}{|l|}{1973} \\
\hline January $16-17$ & 0.012 & 0.023 & 92 & 21.2 & 16.8 & -21 \\
\hline January 18-19 & .046 & .030 & -35 & 50.3 & 26.4 & -48 \\
\hline February 5-8 & .021 & .025 & 19 & 19.8 & 14.0 & -29 \\
\hline February $11-14$ & .158 & .116 & -27 & 89.1 & 38.8 & -56 \\
\hline \multicolumn{7}{|l|}{1974} \\
\hline January 4-8 & 0.141 & 0.394 & 179 & 52.0 & 80.4 & 55 \\
\hline March 7-9 & .071 & .037 & -48 & 22.8 & 14.3 & -37 \\
\hline \multicolumn{7}{|l|}{1975} \\
\hline March 8-9 & 0.029 & 0.072 & 148 & 26.3 & 35.7 & 36 \\
\hline
\end{tabular}


Table 17. Summary of rainfall and runoff data used to calibrate the 1990-93 rainfall-runoff model at basin 17 , Perris Valley, California

$\left[\mathrm{ft}^{3}\right.$, cubic foot; $\mathrm{ft}^{3} / \mathrm{s}$, cubic foot per second; $\mathrm{ft}^{2}$, square foot.

Total runoff: $\frac{\text { Total runoff volume }\left(\mathrm{ft}^{3}\right)}{\text { Total area of catchment (acre) }} \cdot \frac{12 \text { (inch) }}{43,560\left(\mathrm{ft}^{2}\right)^{]}}$

\begin{tabular}{lccccc}
\hline \multicolumn{1}{c}{ Storm date } & Time & $\begin{array}{c}\text { Total rainfall } \\
\text { (inches) }\end{array}$ & $\begin{array}{c}\text { Total runoff } \\
\text { (inches) }\end{array}$ & $\begin{array}{c}\text { Peak discharge } \\
\left(\mathrm{ft}^{3} / \mathrm{s}\right)\end{array}$ & $\begin{array}{c}\text { Runoff/rainfall } \\
\text { ratio (percent) }\end{array}$ \\
\hline 1991 & & & & & \\
$\quad$ February 27-March 3 & $1130-2400$ & 4.17 & 0.365 & 80.4 & 8 \\
March 18-21 & $2330-2400$ & 1.78 & .057 & 32.4 & 3 \\
& & & & & \\
1992 & & & & & 13 \\
February 11-12 & $0830-2400$ & 2.04 & 0.275 & 307.1 & 10 \\
February 15-16 & $0315-2400$ & .82 & .085 & 67.6 & \\
1993 & & & & & 19 \\
January 5-8 & $2215-2400$ & 2.93 & 0.560 & 121.5 & 16 \\
January 15-19 & $0245-1145$ & 4.41 & .710 & 135.4 & 11 \\
February 7-10 & $1230-2345$ & 1.52 & .328 & 119.2 & 21.0 \\
February 18-20 & $1015-2400$ & 1.69 & .262 & & 15 \\
\hline
\end{tabular}

Table 18. Measured and simulated runoff volumes and peak discharges for all storms used in calibration of the 1990-93 rainfall-runoff model at basin 17, Perris Valley, California

$\left[\mathrm{ft}^{3}\right.$, cubic foot; $\mathrm{ft}^{3} / \mathrm{s}$, cubic foot per second; $\mathrm{ft}^{2}$, square foot.

Runoff volume: $\frac{\text { Total runoff volume }\left(\mathrm{ft}^{3}\right)}{\text { Total area of catchment (acre) }} \cdot \frac{12 \text { (inch) }}{43,560\left(\mathrm{ft}^{2}\right)}$.

Error: (simulated value-measured value)/measured value $\bullet 100]$

\begin{tabular}{|c|c|c|c|c|c|c|}
\hline \multirow[b]{2}{*}{ Storm date } & \multicolumn{3}{|c|}{ Runoff volume(inches) } & \multicolumn{3}{|c|}{ Peak discharge $\left(\mathrm{ft}^{3} / \mathrm{s}\right)$} \\
\hline & Measured & Simulated & $\begin{array}{c}\text { Error } \\
\text { (percent) }\end{array}$ & Measured & Simulated & $\begin{array}{c}\text { Error } \\
\text { (percent) }\end{array}$ \\
\hline \multicolumn{7}{|l|}{1991} \\
\hline February 27-March 3 & 0.365 & 0.630 & 73 & 80.4 & 148.0 & 84 \\
\hline March 18-21 & .057 & .146 & 156 & 32.44 & 46.0 & 42 \\
\hline \multicolumn{7}{|l|}{1992} \\
\hline February 11-12 & 0.275 & 0.424 & 54 & 307.0 & 579.0 & 89 \\
\hline February $15-16$ & .085 & .094 & 11 & 67.6 & 69.4 & 3 \\
\hline \multicolumn{7}{|l|}{1993} \\
\hline January 5-8 & 0.560 & 0.303 & -46 & 122.0 & 103.0 & -16 \\
\hline January $15-19$ & .710 & .611 & -14 & 135.0 & 93.1 & -31 \\
\hline February $7-10$ & .328 & .320 & -2 & 119.0 & 294.0 & 147 \\
\hline February $18-20$ & .264 & .198 & -25 & 71.1 & 69.3 & -3 \\
\hline
\end{tabular}


Table 19. Summary of rainfall and runoff data used to calibrate the 1970-75 rainfall-runoff model at basin 21 , Perris Valley, California

$\left[\mathrm{ft}^{3}\right.$, cubic foot; $\mathrm{ft}^{3} / \mathrm{s}$, cubic foot per second; $\mathrm{ft}^{2}$, square foot.

Total runoff: $\frac{\text { Total runoff volume }\left(\mathrm{ft}^{3}\right)}{\text { Total area of catchment (acre) }} \cdot \frac{12 \text { (inch) }}{43,560\left(\mathrm{ft}^{2}\right)^{]}}$

\begin{tabular}{lccccc}
\hline \multicolumn{1}{c}{ Storm date } & Time & $\begin{array}{c}\text { Total rainfall } \\
\text { (inches) }\end{array}$ & $\begin{array}{c}\text { Total runoff } \\
\text { (inches) }\end{array}$ & $\begin{array}{c}\text { Peak discharge } \\
\left(\mathrm{ft}^{3} / \mathrm{s}\right)\end{array}$ & $\begin{array}{c}\text { Runoff/rainfall } \\
\text { ratio (percent) }\end{array}$ \\
\hline $\begin{array}{l}\text { 1970 } \\
\text { March 3-4 }\end{array}$ & $1945-2400$ & 0.53 & 0.031 & 299.0 & 6 \\
$\quad$ November 28-30 & $1715-2400$ & 1.36 & .019 & 183.0 & 1 \\
1973 & & & & & \\
$\quad$ February 11-14 & $0215-2400$ & 1.72 & 0.214 & 914.0 & 12 \\
$\quad$ March 20-22 & $0600-2400$ & .70 & .022 & 173.0 & 3 \\
1974 & & & & & \\
$\quad$ January 4-8 & & & & & \\
$\quad$ March 7-9 & $0600-2400$ & 4.39 & 0.238 & 794.0 & 5 \\
\hline
\end{tabular}

Table 20. Measured and simulated runoff volumes and peak discharges for all storms used in calibration of the 1970-75 rainfall-runoff model at basin 21, Perris Valley, California

$\left[\mathrm{ft}^{3}\right.$, cubic foot; $\mathrm{ft}^{3} / \mathrm{s}$, cubic foot per second; $\mathrm{ft}^{2}$, square foot.

Runoff volume: $\frac{\text { Total runoff volume }\left(\mathrm{ft}^{3}\right)}{\text { Total area of catchment (acre) }} \cdot \frac{12 \text { (inch) }}{43,560\left(\mathrm{ft}^{2}\right)}$.

Error: (simulated value-measured value)/measured value $\bullet 100]$

\begin{tabular}{|c|c|c|c|c|c|c|}
\hline \multirow[b]{2}{*}{ Storm date } & \multicolumn{3}{|c|}{ Runoff volume (inches) } & \multicolumn{3}{|c|}{ Peak discharge $\left(\mathrm{ft}^{3} / \mathrm{s}\right)$} \\
\hline & Measured & Simulated & $\begin{array}{c}\text { Error } \\
\text { (percent) }\end{array}$ & Measured & Simulated & $\begin{array}{c}\text { Error } \\
\text { (percent) }\end{array}$ \\
\hline \multicolumn{7}{|l|}{$\overline{1970}$} \\
\hline March 3-4 & 0.031 & 0.027 & -13 & 299.0 & 194.0 & -35 \\
\hline November $28-30$ & .019 & .051 & 168 & 183.0 & 230.0 & 26 \\
\hline \multicolumn{7}{|l|}{1973} \\
\hline February 11-14 & 0.214 & 0.102 & -52 & 914.0 & 380.0 & -58 \\
\hline March 20-22 & .022 & .044 & 100 & 173.0 & 164.0 & -5 \\
\hline \multicolumn{7}{|l|}{1974} \\
\hline January $4-8$ & 0.238 & 0.357 & 50 & 794.0 & 893.0 & 12 \\
\hline March 7-9 & .037 & .034 & -8 & 166.0 & 130.0 & -22 \\
\hline
\end{tabular}


Table 21. Summary of rainfall and runoff data used to calibrate and verify the 1990-93 rainfall-runoff model at basin 21, Perris Valley, California

$\left[\mathrm{ft}^{3}\right.$, cubic foot; $\mathrm{ft}^{3} / \mathrm{s}$, cubic foot per second; $\mathrm{ft}^{2}$, square foot.

Total runoff: $\left.\frac{\text { Total runoff volume }\left(\mathrm{ft}^{3}\right)}{\text { Total area of catchment (acre) }} \cdot \frac{12 \text { (inch) }}{43,560\left(\mathrm{ft}^{2}\right)^{2}}\right]$

\begin{tabular}{|c|c|c|c|c|c|}
\hline Storm date & Time & $\begin{array}{l}\text { Total rainfall } \\
\text { (inches) }\end{array}$ & $\begin{array}{l}\text { Total runoff } \\
\text { (inches) }\end{array}$ & $\begin{array}{l}\text { Peak discharge } \\
\left(\mathrm{ft}^{3} / \mathrm{s}\right)\end{array}$ & $\begin{array}{l}\text { Runoff/rainfall } \\
\text { ratio (percent) }\end{array}$ \\
\hline \multicolumn{6}{|l|}{1990} \\
\hline February 17-19 & $0300-2400$ & 1.55 & 0.122 & $1,090.0$ & 7 \\
\hline \multicolumn{6}{|l|}{1991} \\
\hline January 3-5 & $0515-2400$ & 0.94 & 0.137 & 881.0 & 14 \\
\hline January 9-10 & $1015-1100$ & .34 & .023 & 280.0 & 6 \\
\hline February 27-March 3 & $1130-2300$ & 4.00 & .653 & $1,540.0$ & 16 \\
\hline March 13-14 & $1445-2400$ & .20 & .022 & 257.0 & 11 \\
\hline March 18-21 & $2330-2400$ & 2.06 & .214 & $1,010.0$ & 10 \\
\hline March 25-28 & $0345-1200$ & 2.46 & .410 & $2,080.0$ & 16 \\
\hline December 27-30 & $2345-2400$ & 1.07 & .054 & 257.0 & 5 \\
\hline \multicolumn{6}{|l|}{1992} \\
\hline January 5-8 & $0445-2400$ & 1.63 & 0.223 & 814.0 & 13 \\
\hline February 5-8 & $1930-1200$ & 1.23 & .047 & 271.0 & 3 \\
\hline February $11-13$ & $0830-1200$ & 1.75 & .525 & $4,400.0$ & 30 \\
\hline February $15-16$ & $0315-2400$ & .86 & .152 & $1,390.0$ & 17 \\
\hline $\operatorname{March} 2-4$ & $0400-2400$ & 1.10 & .037 & 188.0 & 3 \\
\hline March 6-8 & $0615-2400$ & .30 & .043 & 626.0 & 14 \\
\hline March 20-24 & $1415-2400$ & 1.66 & .180 & 717.0 & 10 \\
\hline December 6-8 & $1815-1200$ & 2.83 & .383 & $2,340.0$ & 13 \\
\hline December 27-31 & $1715-2345$ & 1.24 & .082 & 601.0 & 6 \\
\hline \multicolumn{6}{|l|}{1993} \\
\hline January 5-8 & $2215-2345$ & 2.93 & 0.722 & $2,030.0$ & 24 \\
\hline January $15-19$ & $0245-1912$ & 4.41 & 1.504 & $2,610.0$ & 34 \\
\hline February $7-10$ & $1230-2400$ & 1.52 & .561 & $2,610.0$ & 36 \\
\hline February $14-15$ & $1730-1200$ & .21 & .022 & 210.0 & 10 \\
\hline February $18-20$ & $1015-2400$ & 1.69 & .309 & $1,150.0$ & 18 \\
\hline
\end{tabular}


Table 22. Measured and simulated runoff volumes and peak discharges for all storms used in calibration and verification of the 1990-93 rainfall-runoff model at basin 21, Perris Valley, California

[ $\mathrm{ft}^{3}$, cubic foot; $\mathrm{ft}^{3} / \mathrm{s}$, cubic foot per second; $\mathrm{ft}^{2}$, square foot.

Runoff volume: $\frac{\text { Total runoff volume }\left(\mathrm{ft}^{3}\right)}{\text { Total area of catchment (acre) }} \cdot \frac{12 \text { (inch) }}{43,560\left(\mathrm{ft}^{2}\right)}$.

Error: (simulated value-measured value)/measured value $\bullet 100]$

\begin{tabular}{|c|c|c|c|c|c|c|}
\hline \multirow[b]{2}{*}{ Storm date } & \multicolumn{3}{|c|}{ Runoff volume (inches) } & \multicolumn{3}{|c|}{ Peak discharge $\left(\mathrm{ft}^{3} / \mathrm{s}\right)$} \\
\hline & Measured & Simulated & $\begin{array}{c}\text { Error } \\
\text { (percent) }\end{array}$ & Measured & Simulated & $\begin{array}{c}\text { Error } \\
\text { (percent) }\end{array}$ \\
\hline \multicolumn{7}{|c|}{ Calibration } \\
\hline \multicolumn{7}{|l|}{$\overline{1991}$} \\
\hline January $9-10$ & 0.023 & 0.032 & 39 & 280.0 & 545.0 & 95 \\
\hline February 27-March 3 & .653 & .801 & 23 & $1,540.0$ & $1,983.0$ & 29 \\
\hline March 13-14 & .022 & .024 & 9 & 257.0 & 479.0 & 86 \\
\hline March 18-21 & .214 & .251 & 17 & $1,010.0$ & $1,200.0$ & 19 \\
\hline March 25-28 & .410 & .579 & 41 & $2,080.0$ & $4,250.0$ & 104 \\
\hline \multicolumn{7}{|l|}{1992} \\
\hline January 5-8 & 0.223 & 0.157 & -30 & 814.0 & 607.0 & -25 \\
\hline February $11-13$ & .525 & .512 & -2 & $4,400.0$ & $6,460.0$ & 47 \\
\hline March 6-8 & .043 & .024 & -44 & 626.0 & 413.0 & -34 \\
\hline \multicolumn{7}{|l|}{1993} \\
\hline February $7-10$ & 0.561 & 0.410 & -27 & $2,610.0$ & $4,000.0$ & 53 \\
\hline February $14-15$ & .022 & .011 & -50 & 211.0 & 194.0 & -8 \\
\hline February $18-20$ & .309 & .262 & -15 & $1,150.0$ & $1,210.0$ & 5 \\
\hline \multicolumn{7}{|c|}{ Verification } \\
\hline 1990 & & & & & & \\
\hline February $17-19$ & 0.122 & 0.111 & -9 & $1,090.0$ & 806.0 & -26 \\
\hline \multicolumn{7}{|l|}{1991} \\
\hline January 3-5 & 0.137 & 0.116 & -15 & 881.0 & 740.0 & -16 \\
\hline December 27-30 & .054 & .079 & 46 & 257.0 & 573.0 & 123 \\
\hline \multicolumn{7}{|l|}{1992} \\
\hline February 5-8 & 0.047 & 0.069 & 47 & 271.0 & 478.11 & 76 \\
\hline February $15-16$ & .152 & .152 & 0 & $1,387.0$ & $1,382.0$ & 0 \\
\hline March 2-4 & .037 & .081 & 119 & 188.0 & 489.0 & 160 \\
\hline March 20-24 & .180 & .189 & 5 & 717.0 & $1,200.0$ & 67 \\
\hline December 6-8 & .383 & .545 & 42 & $2,340.0$ & $4,800.0$ & 105 \\
\hline December 27-31 & .082 & .110 & 34 & 601.0 & 837.0 & 39 \\
\hline \multicolumn{7}{|l|}{1993} \\
\hline January 5-8 & 0.722 & 0.402 & -44 & $2,040.0$ & $1,540.0$ & -25 \\
\hline January $15-19$ & 1.504 & .875 & -42 & $2,610.0$ & $2,040.0$ & -22 \\
\hline
\end{tabular}


Table 23. Median absolute deviation errors for calibration and verification of runoff volumes and peak discharges, Perris Valley, California

[--. no data]

\begin{tabular}{|c|c|c|c|c|}
\hline \multirow[t]{2}{*}{ Basin } & \multicolumn{2}{|c|}{$\begin{array}{l}\text { Calibration } \\
\text { errors } \\
\text { (percent) }\end{array}$} & \multicolumn{2}{|c|}{$\begin{array}{c}\text { Verification } \\
\text { errors } \\
\text { (percent) }\end{array}$} \\
\hline & $\begin{array}{c}\text { Runoff } \\
\text { volumes }\end{array}$ & $\begin{array}{c}\text { Peak } \\
\text { discharge }\end{array}$ & $\begin{array}{c}\text { Runoff } \\
\text { volumes }\end{array}$ & $\begin{array}{c}\text { Peak } \\
\text { discharge }\end{array}$ \\
\hline \multicolumn{5}{|c|}{ 1970-75 Model } \\
\hline 9 & 43 & 34 & $\overline{--}$ & $\overline{--}$ \\
\hline 15 & 34 & 22 & -- & -- \\
\hline 17 & 35 & 36 & -- & -- \\
\hline 21 & 31 & 24 & - & -- \\
\hline Average & 36 & 29 & -- & -- \\
\hline \multicolumn{5}{|c|}{ 1990-93 Model } \\
\hline 9 & 30 & 32 & 38 & 43 \\
\hline 15 & 17 & 35 & 26 & 48 \\
\hline 17 & 35 & 36 & -- & -- \\
\hline 21 & 27 & 34 & 42 & 39 \\
\hline Average & 27 & 34 & 35 & 43 \\
\hline
\end{tabular}

Table 24. Monthly rainfall totals at Riverside Citrus Experimental Station and at basin 15, Perris Valley, California [All values are in inches. Blank, no rainfall; --, no data; n/a, not applicable]

\begin{tabular}{|c|c|c|c|c|c|c|c|c|c|c|c|c|c|}
\hline & Oct & Nov & Dec & $\operatorname{Jan}$ & Feb & $\begin{array}{r}\text { Mar } \\
1990\end{array}$ & Apr & May & June & July & Aug & Sept & Total \\
\hline Riverside & 0.26 & 0.11 & & 1.64 & 2.42 & 0.37 & 0.52 & 0.45 & 0.03 & & & & 5.80 \\
\hline Perris Valley & .13 & .45 & & 1.57 & 1.95 & .23 & .43 & .75 & .25 & & & & 5.76 \\
\hline \multicolumn{14}{|c|}{1991} \\
\hline Riverside & 0.04 & 0.33 & & 1.54 & 2.96 & 5.58 & 0.04 & 0.03 & & 0.10 & & & 10.62 \\
\hline Perris Valley & & .61 & & 1.29 & 2.86 & 6.16 & .01 & .18 & & .08 & & & 11.19 \\
\hline \multicolumn{14}{|c|}{1992} \\
\hline Riverside & 0.30 & 0.08 & 1.30 & 1.96 & 4.08 & 3.22 & $\overline{0.02}$ & 0.11 & & 0.13 & & & 11.20 \\
\hline Perris Valley & .13 & .02 & 1.38 & 1.87 & 4.34 & 3.63 & .10 & .17 & & .36 & & & 12.00 \\
\hline \multicolumn{14}{|c|}{1993} \\
\hline Riverside & 0.58 & & 3.24 & 9.31 & 5.05 & 1.04 & $\mathrm{n} / \mathrm{a}$ & $\mathrm{n} / \mathrm{a}$ & $\mathrm{n} / \mathrm{a}$ & $\mathrm{n} / \mathrm{a}$ & $\mathrm{n} / \mathrm{a}$ & $\mathrm{n} / \mathrm{a}$ & 18.64 \\
\hline Perris Valley & & & 4.56 & 7.79 & 3.59 & .42 & - & -- & -- & - & -- & -- & 16.36 \\
\hline
\end{tabular}


Table 25. Summary of monthly and annual rainfall totals at Riverside Citrus Experimental Station, California [All values are in inches. Blank, no rainfall]

\begin{tabular}{|c|c|c|c|c|c|c|c|c|c|c|c|c|c|}
\hline Year & Oct & Nov & Dec & Jan & Feb & Mar & Apr & May & June & July & Aug & Sept & Total \\
\hline 1949 & 0.87 & 0.03 & 1.64 & 2.85 & 1.22 & 0.52 & 0.01 & 0.57 & & & & & 7.71 \\
\hline 1950 & .09 & 1.23 & 1.49 & 1.76 & 2.06 & .72 & .66 & .15 & 0.04 & & & 0.04 & 8.24 \\
\hline 1951 & & 1.15 & .01 & 1.42 & .52 & .48 & 1.55 & .55 & & & 0.05 & .31 & 6.04 \\
\hline 1952 & .60 & .69 & 5.02 & 3.42 & .36 & 3.62 & 1.57 & & & 0.06 & & .41 & 15.75 \\
\hline 1953 & & 2.47 & 1.15 & .78 & .34 & .61 & 1.09 & & & & & & 6.44 \\
\hline 1954 & & .65 & .33 & 3.80 & 1.55 & 2.94 & & .01 & & .05 & .02 & & 9.35 \\
\hline 1955 & & 2.28 & .65 & 2.62 & 1.08 & .20 & .62 & .49 & & & & & 7.94 \\
\hline 1956 & & .79 & .50 & .19 & .24 & .02 & 1.42 & .14 & & .17 & & & 3.47 \\
\hline 1957 & & & .35 & 3.49 & .84 & .67 & 1.14 & .79 & & & & & 7.28 \\
\hline 1958 & 4.20 & .94 & 2.10 & 1.14 & 1.46 & 3.11 & 2.79 & .18 & .06 & & .10 & .37 & 16.45 \\
\hline 1959 & .12 & .17 & & .39 & 2.28 & & & .06 & & & & & 3.02 \\
\hline 1960 & & & 1.64 & 1.75 & 1.75 & .22 & & & & & & & 5.36 \\
\hline 1961 & & 1.18 & .16 & .65 & & .46 & & .05 & & & 1.12 & & 3.62 \\
\hline 1962 & & .59 & 1.30 & 1.79 & 2.94 & .68 & & .44 & & & & & 7.74 \\
\hline 1963 & & & & .10 & 2.06 & 1.22 & 1.38 & & .14 & & .11 & 3.04 & 8.05 \\
\hline 1964 & .42 & 1.74 & & .63 & .20 & 1.72 & .62 & .06 & & & & .12 & 5.51 \\
\hline 1965 & .08 & 1.16 & .64 & .44 & .13 & 1.78 & 3.61 & .06 & .04 & .08 & & .27 & 8.29 \\
\hline 1966 & & 5.34 & 2.51 & & .03 & .62 & & & & & & & 8.50 \\
\hline 1967 & .55 & .06 & .26 & 2.23 & & 1.21 & 1.40 & .07 & .01 & & .61 & .68 & 7.08 \\
\hline 1968 & & 2.48 & 1.71 & .60 & .37 & 1.22 & 1.03 & .10 & .07 & .29 & .14 & & 8.01 \\
\hline 1969 & .11 & .71 & .70 & 5.80 & 6.66 & .58 & .33 & .46 & & & & & 15.35 \\
\hline 1970 & & .70 & .04 & 1.08 & 1.89 & 1.71 & .02 & .01 & & & .30 & & 5.75 \\
\hline 1971 & .01 & 2.04 & 2.58 & .74 & .36 & .12 & .32 & .41 & & & & & 6.58 \\
\hline 1972 & .51 & .09 & 3.22 & & .10 & & & .10 & .23 & & & .06 & 4.31 \\
\hline 1973 & .16 & 2.03 & 1.34 & 1.93 & 4.03 & 2.88 & & & & & .02 & & 12.39 \\
\hline 1974 & .13 & 1.36 & .06 & 4.17 & .27 & 1.71 & .44 & .01 & & & & & 8.15 \\
\hline 1975 & .16 & .02 & 1.74 & & 1.40 & 3.90 & 2.00 & .20 & & & & .20 & 9.62 \\
\hline 1976 & .10 & 1.20 & .30 & & 4.60 & 1.40 & 1.20 & .90 & .30 & .05 & & 2.38 & 12.43 \\
\hline 1977 & .07 & .54 & .40 & 2.04 & .90 & .83 & & 1.66 & .02 & & 2.58 & & 9.04 \\
\hline 1978 & & & 2.39 & 5.62 & 4.57 & 5.61 & 1.36 & & & & .03 & .98 & 20.56 \\
\hline 1979 & .12 & 1.75 & 1.83 & 6.80 & 1.92 & 3.30 & & .41 & & .17 & .02 & & 16.32 \\
\hline 1980 & .84 & .12 & .20 & 4.88 & 6.15 & 3.56 & .75 & .28 & & & & & 16.78 \\
\hline 1981 & .04 & & .13 & 2.34 & 1.20 & 2.18 & .31 & .05 & & & & .16 & 6.41 \\
\hline 1982 & .33 & 1.19 & .31 & 2.90 & 1.29 & 4.71 & 1.22 & .44 & .09 & & .01 & .39 & 12.88 \\
\hline 1983 & .08 & 3.10 & .92 & 3.15 & 3.66 & 5.83 & 3.00 & .43 & & & 1.45 & 1.24 & 22.86 \\
\hline 1984 & .73 & 1.96 & 1.54 & .18 & .02 & .17 & .17 & .02 & .05 & .12 & .01 & .11 & 5.08 \\
\hline 1985 & .10 & .68 & 3.99 & .93 & .79 & .62 & & .03 & .05 & & & .28 & 7.47 \\
\hline 1986 & .10 & 3.37 & .95 & 1.94 & 3.27 & .66 & & & & .16 & .51 & .33 & 11.29 \\
\hline 1987 & .34 & .42 & .65 & 1.53 & 1.14 & 1.08 & .26 & & .01 & .15 & & .37 & 5.95 \\
\hline 1988 & 1.68 & .87 & .90 & 1.13 & .69 & .67 & 2.16 & .02 & & & & .03 & 8.15 \\
\hline 1989 & & .68 & 2.76 & .89 & 1.68 & .77 & .02 & .15 & .04 & & & .46 & 7.45 \\
\hline 1990 & .26 & -.11 & & 1.64 & 2.42 & .37 & .52 & .45 & .03 & & & & 5.80 \\
\hline 1991 & .04 & .33 & & 1.53 & 2.96 & 5.58 & .04 & .03 & & .10 & & .90 & 11.51 \\
\hline 1992 & .30 & .08 & 1.30 & 1.96 & 4.08 & 3.22 & .02 & .11 & & .26 & & & 11.33 \\
\hline 1993 & .58 & & 3.61 & 9.32 & 5.12 & 1.04 & & .03 & .92 & & & & 20.62 \\
\hline Maximum & 4.20 & 5.34 & 5.02 & 9.32 & 6.66 & 5.83 & 3.61 & 1.66 & .92 & .29 & 2.58 & 3.04 & 22.86 \\
\hline Average & .30 & 1.03 & 1.18 & 2.06 & 1.79 & 1.66 & .73 & .22 & .05 & .04 & .16 & .29 & 9.51 \\
\hline
\end{tabular}


Table 26. Summary of simulated annual peak discharges for the models representing the 1970-75 and $1990-93$ conditions, Perris Valley, California

$\left[\mathrm{ft}^{3} / \mathrm{s}\right.$, cubic foot per second]

\begin{tabular}{cccccc}
\hline Basin & $\begin{array}{c}\text { Mini- } \\
\text { mum } \\
\left(\mathrm{ft}^{3} / \mathrm{s}\right)\end{array}$ & $\begin{array}{c}\text { Maxi- } \\
\text { mum } \\
\left(\mathrm{ft}^{3} / \mathrm{s}\right)\end{array}$ & $\begin{array}{c}\text { Aver- } \\
\text { age } \\
\left(\mathrm{ft}^{3} / \mathrm{s}\right)\end{array}$ & $\begin{array}{c}\text { Stand- } \\
\text { ard } \\
\text { devia- } \\
\text { tion } \\
\left(\mathrm{ft}^{3} / \mathrm{s}\right)\end{array}$ & $\begin{array}{c}\text { Number } \\
\text { of } \\
\text { annual } \\
\text { peaks }\end{array}$ \\
\hline \multicolumn{6}{c}{$\mathbf{1 9 7 0 - 7 5}$ Model } \\
\hline 9 & 68 & 1,380 & 307 & 288 & 45 \\
15 & 138 & 4,710 & 929 & 1,110 & 45 \\
17 & 18 & 508 & 115 & 115 & 45 \\
21 & 163 & 6,470 & 1,320 & 1,640 & 45 \\
\multicolumn{7}{c}{} & $1990-93$ Model & & \\
\hline 9 & 174 & 1,780 & 506 & 328 & 45 \\
15 & 392 & 5,360 & 1,430 & 1,190 & 45 \\
17 & 19 & 573 & 124 & 134 & 45 \\
21 & 454 & 8,530 & 2,050 & 1,960 & 45 \\
\hline
\end{tabular}

Table 28. Summary of simulated storm peak discharges for the models representing the 1970-75 and $1990-93$ conditions, Perris Valley, California

$\left[\mathrm{ft}^{3} / \mathrm{s}\right.$, cubic foot per second]

\begin{tabular}{cccccc}
\hline Basin & $\begin{array}{c}\text { Mini- } \\
\text { mum } \\
\left(\mathrm{ft}^{3} / \mathrm{s}\right)\end{array}$ & $\begin{array}{c}\text { Maxi- } \\
\text { mum } \\
\left(\mathrm{ft}^{3} / \mathrm{s}\right)\end{array}$ & $\begin{array}{c}\text { Aver- } \\
\text { age } \\
\left(\mathrm{ft}^{3} / \mathrm{s}\right)\end{array}$ & $\begin{array}{c}\text { Stand- } \\
\text { ard } \\
\text { devia- } \\
\text { tion } \\
\left(\mathrm{ft}^{3} / \mathrm{s}\right)\end{array}$ & $\begin{array}{c}\text { Number } \\
\text { of } \\
\text { storms }\end{array}$ \\
\hline \multicolumn{6}{c}{$\mathbf{1 9 7 0 - 7 5}$ Model } \\
\hline 9 & 0.70 & 1,350 & 44.9 & 96.4 & 925 \\
15 & 1.10 & 4,710 & 120.0 & 329.0 & 925 \\
17 & .10 & 507 & 13.0 & 36.0 & 925 \\
21 & 1.50 & 6,470 & 157.0 & 478.0 & 925 \\
\multicolumn{7}{c}{} \\
\hline 9 & 1.30 & 1,780 & 104.0 & 151.0 & 925 \\
15 & 3.10 & 5,360 & 270.0 & 439.0 & 925 \\
17 & .01 & 573 & 14.6 & 42.2 & 925 \\
21 & 3.40 & 8,530 & 337.0 & 657.0 & 925 \\
\hline \multicolumn{7}{c}{}
\end{tabular}

Table 27. Summary of simulated annual runoff volumes for the models representing the 1970-75 and 1990-93 conditions, Perris Valley, California

\begin{tabular}{cccccc}
\hline Basin & $\begin{array}{c}\text { Mini- } \\
\text { mum } \\
\text { (acre- } \\
\text { feet) }\end{array}$ & $\begin{array}{c}\text { Maxi- } \\
\text { mum } \\
\text { (acre- } \\
\text { feet) }\end{array}$ & $\begin{array}{c}\text { Aver- } \\
\text { age } \\
\text { (acre- } \\
\text { feet) }\end{array}$ & $\begin{array}{c}\text { Stand- } \\
\text { ard } \\
\text { devia- } \\
\text { tion } \\
\text { (acre-feet) }\end{array}$ & $\begin{array}{c}\text { Number } \\
\text { of } \\
\text { years }\end{array}$ \\
\hline \multicolumn{5}{c}{$\mathbf{1 9 7 0 - 7 5 ~ M o d e l ~}$} \\
\hline 9 & 94 & 1,940 & 530 & 450 & 45 \\
15 & 292 & 7,060 & 1,830 & 1,660 & 45 \\
17 & 37 & 813 & 199 & 170 & 45 \\
21 & 379 & 9,370 & 2,360 & 2,180 & 45 \\
\multicolumn{5}{c}{} \\
\hline 9 & 231 & 3,330 & 982 & 677 & 45 \\
15 & 752 & 11,300 & 3,380 & 2,450 & 45 \\
17 & 38 & 968 & 239 & 218 & 45 \\
21 & 955 & 15,900 & 4,520 & 3,460 & 45 \\
\hline \multicolumn{5}{c}{}
\end{tabular}


Table 29. Model and regional frequency analyses of annual peak discharges at basins $9,15,17$, and 21 , Perris Valley, California

[1970-75 and 1990-93 regional frequency analyses adjusted for urban conditions in 1970-75 and 1990-93, respectively. $\mathrm{ft}^{3} / \mathrm{s}$, cubic foot per second]

\begin{tabular}{|c|c|c|c|c|c|c|}
\hline \multirow{3}{*}{ Return period (years) } & \multicolumn{3}{|c|}{ Model frequency analysis $\left(\mathrm{ft}^{3} / \mathrm{s}\right)$} & \multicolumn{3}{|c|}{ Regional frequency analysis $\left(\mathrm{ft}^{3} / \mathrm{s}\right)$} \\
\hline & \multirow[t]{2}{*}{ Discharge } & \multicolumn{2}{|c|}{$\begin{array}{l}\text { Confidence limits for } \\
\text { standard error of estimate }\end{array}$} & \multirow[t]{2}{*}{ Discharge } & \multicolumn{2}{|c|}{$\begin{array}{l}\text { Confidence limits for } \\
\text { standard error of estimate }\end{array}$} \\
\hline & & Lower & Upper & & Lower & Upper \\
\hline \multicolumn{7}{|c|}{ Basin 9} \\
\hline \multicolumn{7}{|c|}{ 1970-75 conditions } \\
\hline 2 & 205 & 194 & 216 & 51 & 17 & 151 \\
\hline 5 & 419 & 395 & 445 & 183 & 78 & 429 \\
\hline 10 & 632 & 590 & 682 & 360 & 168 & 770 \\
\hline 25 & 1,013 & 930 & 1,111 & 715 & 342 & 1,494 \\
\hline 50 & 1,396 & 1,267 & 1,552 & 1,098 & 490 & 2,458 \\
\hline 100 & 1,886 & 1,691 & 2,124 & 1,512 & 616 & 3,712 \\
\hline \multicolumn{7}{|c|}{ 1990-93 conditions } \\
\hline 2 & 409 & 394 & 423 & 86 & 29 & 254 \\
\hline 5 & 663 & 638 & 691 & 277 & 118 & 649 \\
\hline 10 & 885 & 844 & 930 & 485 & 227 & 1,037 \\
\hline 25 & 1,236 & 1,166 & 1,317 & 949 & 454 & 1,983 \\
\hline 50 & 1,559 & 1,458 & 1,676 & 1,350 & 603 & 3,022 \\
\hline 100 & 1,940 & 1,799 & 2,106 & 1,764 & 719 & 4,330 \\
\hline \multicolumn{7}{|c|}{ Basin 15} \\
\hline \multicolumn{7}{|c|}{ 1970-75 conditions } \\
\hline 2 & 473 & 442 & 506 & 140 & 47 & 413 \\
\hline 5 & 1,189 & 1,103 & 1,287 & 543 & 232 & 1,273 \\
\hline 10 & 2,062 & 1,886 & 2,268 & 1,050 & 491 & 2,245 \\
\hline 25 & 3,914 & 3,503 & 4,411 & 2,220 & 1,063 & 4,638 \\
\hline 50 & 6,103 & 5,373 & 7,007 & 3,420 & 1,528 & 7,656 \\
\hline 100 & 9,292 & 8,047 & 10,865 & 4,850 & 1,976 & 11,905 \\
\hline \multicolumn{7}{|c|}{ 1990-93 conditions } \\
\hline 2 & 1,014 & 969 & 1,061 & 222 & 75 & 655 \\
\hline 5 & 1,891 & 1,798 & 1,993 & 746 & 318 & 1,749 \\
\hline 10 & 2,754 & 2,593 & 2,936 & 1,440 & 674 & 3,079 \\
\hline 25 & 4,278 & 3,969 & 4,639 & 2,800 & 1,340 & 5,850 \\
\hline 50 & 5,816 & 5,334 & 6,388 & 4,210 & 1,881 & 9,425 \\
\hline 100 & 7,785 & 7,059 & 8,659 & 5,570 & 2,269 & 13,673 \\
\hline
\end{tabular}


Table 29. Model and regional frequency analyses of annual peak discharges at basins $9,15,17$, and 21 , Perris Valley, California--Continued

\begin{tabular}{|c|c|c|c|c|c|c|}
\hline \multirow{3}{*}{ Return period (years) } & \multicolumn{3}{|c|}{ Model frequency analysis $\left(\mathrm{ft}^{3} / \mathrm{s}\right)$} & \multicolumn{3}{|c|}{ Regional frequency analysis $\left(\mathrm{ft}^{3} / \mathrm{s}\right)$} \\
\hline & \multirow[t]{2}{*}{ Discharge } & \multicolumn{2}{|c|}{$\begin{array}{l}\text { Confidence limits for } \\
\text { standard error of estimate }\end{array}$} & \multirow[t]{2}{*}{ Discharge } & \multicolumn{2}{|c|}{$\begin{array}{l}\text { Confidence limits for } \\
\text { standard error of estimate }\end{array}$} \\
\hline & & Lower & Upper & & Lower & Upper \\
\hline \multicolumn{7}{|c|}{ Basin 17} \\
\hline \multicolumn{7}{|c|}{ 1970-75 conditions } \\
\hline 2 & 61 & 57 & 64 & 37 & 13 & 109 \\
\hline 5 & 140 & 131 & 151 & 141 & 60 & 331 \\
\hline 10 & 230 & 212 & 251 & 214 & 100 & 458 \\
\hline 25 & 406 & 367 & 453 & 432 & 207 & 903 \\
\hline 50 & 601 & 535 & 681 & 654 & 292 & 1,464 \\
\hline 100 & 869 & 763 & 1,000 & 893 & 364 & 2,192 \\
\hline \multicolumn{7}{|c|}{ 1990-93 conditions } \\
\hline 2 & 70 & 65 & 74 & 50 & 17 & 148 \\
\hline 5 & 166 & 155 & 179 & 184 & 78 & 431 \\
\hline 10 & 275 & 252 & 301 & 272 & 127 & 582 \\
\hline 25 & 488 & 440 & 546 & 532 & 255 & 1,112 \\
\hline 50 & 722 & 641 & 821 & 785 & 351 & 1,757 \\
\hline 100 & 1,041 & 911 & 1,203 & 1,050 & 428 & 2,577 \\
\hline \multicolumn{7}{|c|}{ Basin 21 } \\
\hline \multicolumn{7}{|c|}{$1970-75$ conditions } \\
\hline 2 & 646 & 603 & 692 & 198 & 67 & 584 \\
\hline 5 & 1,673 & 1,548 & 1,815 & 758 & 323 & 1,777 \\
\hline 10 & 2,951 & 2,691 & 3,257 & 1,490 & 697 & 3,186 \\
\hline 25 & 5,712 & 5,094 & 6,462 & 3,130 & 1,498 & 6,539 \\
\hline 50 & 9,024 & 7,912 & 10,406 & 4,810 & 2,149 & 10,768 \\
\hline 100 & 13,907 & 11,990 & 16,343 & 6,840 & 2,786 & 16,790 \\
\hline \multicolumn{7}{|c|}{$1990-93$ conditions } \\
\hline 2 & 1,328 & 1,261 & 1,399 & 290 & 98 & 856 \\
\hline 5 & 2,716 & 2,562 & 2,886 & 1,030 & 439 & 2,415 \\
\hline 10 & 4,168 & 3,889 & 4,487 & 1,930 & 903 & 4,126 \\
\hline 25 & 6,869 & 6,303 & 7,537 & 3,840 & 1,838 & 8,023 \\
\hline 50 & 9,718 & 8,803 & 10,819 & 5,890 & 2,631 & 13,186 \\
\hline 100 & 13,498 & 12,070 & 15,244 & 7,980 & 3,251 & 19,589 \\
\hline
\end{tabular}


Table 30. Model frequency analyses of annual runoff volumes at basins $9,15,17$, and 21, Perris Valley, California

\begin{tabular}{|c|c|c|c|c|c|c|c|}
\hline \multirow{3}{*}{$\begin{array}{l}\text { Return } \\
\text { period } \\
\text { (years) }\end{array}$} & \multicolumn{3}{|c|}{$\begin{array}{l}\text { Model frequency analysis } \\
\text { (acre-feet) }\end{array}$} & \multirow{3}{*}{$\begin{array}{l}\text { Return } \\
\text { period } \\
\text { (years) }\end{array}$} & \multicolumn{3}{|c|}{$\begin{array}{l}\text { Model frequency analysis } \\
\text { (acre-feet) }\end{array}$} \\
\hline & \multirow[t]{2}{*}{ Volume } & \multicolumn{2}{|c|}{$\begin{array}{c}\text { Confidence limits for } \\
\text { standard error of estimate }\end{array}$} & & \multirow[t]{2}{*}{ Volume } & \multicolumn{2}{|c|}{$\begin{array}{l}\text { Confidence limits for } \\
\text { standard error of estimate }\end{array}$} \\
\hline & & Lowe & Upper & & & Lowe & Upper \\
\hline \multicolumn{4}{|c|}{ Basin 9} & \multicolumn{4}{|c|}{ Basin 17} \\
\hline \multicolumn{4}{|c|}{$1970-75$ conditions } & \multicolumn{4}{|c|}{$1970-75$ conditions } \\
\hline 2 & 377 & 359 & 396 & 2 & 142 & 135 & 149 \\
\hline 5 & 732 & 693 & 777 & 5 & 275 & 260 & 291 \\
\hline 10 & 1,065 & 997 & 1,142 & 10 & 399 & 373 & 428 \\
\hline 25 & 1,623 & 1,499 & 1,768 & 25 & 607 & 560 & 662 \\
\hline 50 & 2,156 & 1,971 & 2,377 & 50 & 806 & 736 & 889 \\
\hline 100 & 2,807 & 2,340 & 3,129 & 100 & 1,049 & 948 & 1,170 \\
\hline \multicolumn{4}{|c|}{$1990-93$ conditions } & \multicolumn{4}{|c|}{$1990-93$ conditions } \\
\hline 2 & 781 & 750 & 814 & 2 & 161 & 153 & 170 \\
\hline 5 & 1,343 & 1,282 & 1,410 & 5 & 330 & 311 & 352 \\
\hline 10 & 1,817 & 1,721 & 1,926 & 10 & 495 & 461 & 533 \\
\hline 25 & 2,545 & 2,383 & 2,731 & 25 & 779 & 715 & 854 \\
\hline 50 & 3,189 & 2,961 & 3,455 & 50 & 1,059 & 961 & 1,176 \\
\hline 100 & 3,928 & 3,618 & 4,294 & 100 & 1,407 & 1,263 & 1,582 \\
\hline \multicolumn{4}{|c|}{ Basin 15} & \multicolumn{4}{|c|}{ Basin 21 } \\
\hline \multicolumn{4}{|c|}{$1970-75$ conditions } & \multicolumn{4}{|c|}{$1970-75$ conditions } \\
\hline 2 & 1,240 & 1,176 & 1,307 & 2 & 1,591 & 1,507 & 1,678 \\
\hline 5 & 2,527 & 2,380 & 2,691 & 5 & 3,266 & 3,075 & 3,480 \\
\hline 10 & 3,777 & 3,521 & 4,072 & 10 & 4,907 & 4,570 & 5,294 \\
\hline 25 & 5,936 & 5,451 & 6,508 & 25 & 7,758 & 7,117 & 8,514 \\
\hline 50 & 8,054 & 7,313 & 8,940 & 50 & 10,569 & 9,587 & 11,748 \\
\hline 100 & 10,690 & 9,601 & 12,012 & 100 & 14,087 & 12,637 & 15,851 \\
\hline \multicolumn{4}{|c|}{$1990-93$ conditions } & \multicolumn{4}{|c|}{$1990-93$ conditions } \\
\hline 2 & 2,619 & 2,508 & 2,733 & 2 & 3,419 & 3,269 & 3,576 \\
\hline 5 & 4,642 & 4,423 & 4,884 & 5 & 6,233 & 5,925 & 6,573 \\
\hline 10 & 6,396 & 6,043 & 6,796 & 10 & 8,734 & 8,229 & 9,306 \\
\hline 25 & 9,150 & 8,543 & 9,853 & 25 & 12,746 & 11,860 & 13,775 \\
\hline 50 & 11,637 & 10,770 & 12,655 & 50 & 16,437 & 15,154 & 17,950 \\
\hline 100 & 14,536 & 13,339 & 15,958 & 100 & 20,805 & 19,008 & 22,950 \\
\hline
\end{tabular}

